A STUDY OF THE CHIRONOMIDAE (DIPTERA) OF AFRICA SOUTH OF

\author{
THE SAHARA
}

PART IV

BY

PAUL FREEMAN

xuf,

Pp. 26I-363; 2 Plates; I5 Text-figures

BULLETIN OF

THE BRITISH MUSEUM (NATURAL HISTORY) ENTOMOLOGY

Vol. 6 No. II

LONDON : 1958 
THE BULLETIN OF THE BRITISH MUSEUM (NATURAL HISTORY), instituted in I949, is issued in five series corresponding to the Departments of the Museum, and an Historical Series.

Parts will appear at irregular intervals as they become ready. Volumes will contain about three or four hundred pages, and will not necessarily be completed within one calendar year.

This paper is Vol. 6, No. II of the Entomological series.

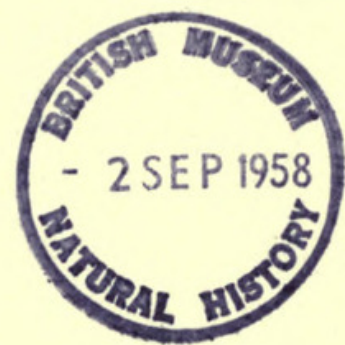

(C) Trustees of the British Museum, 1958

PRINTED BY ORDER OF THE TRUSTEES OF THE BRITISH MUSEUM 


\title{
A STUDY OF THE CHIRONOMIDAE (DIPTERA) OF AFRICA SOUTH OF THE SAHARA PART IV
}

\author{
By PAUL FREEMAN
}

CONTENTS

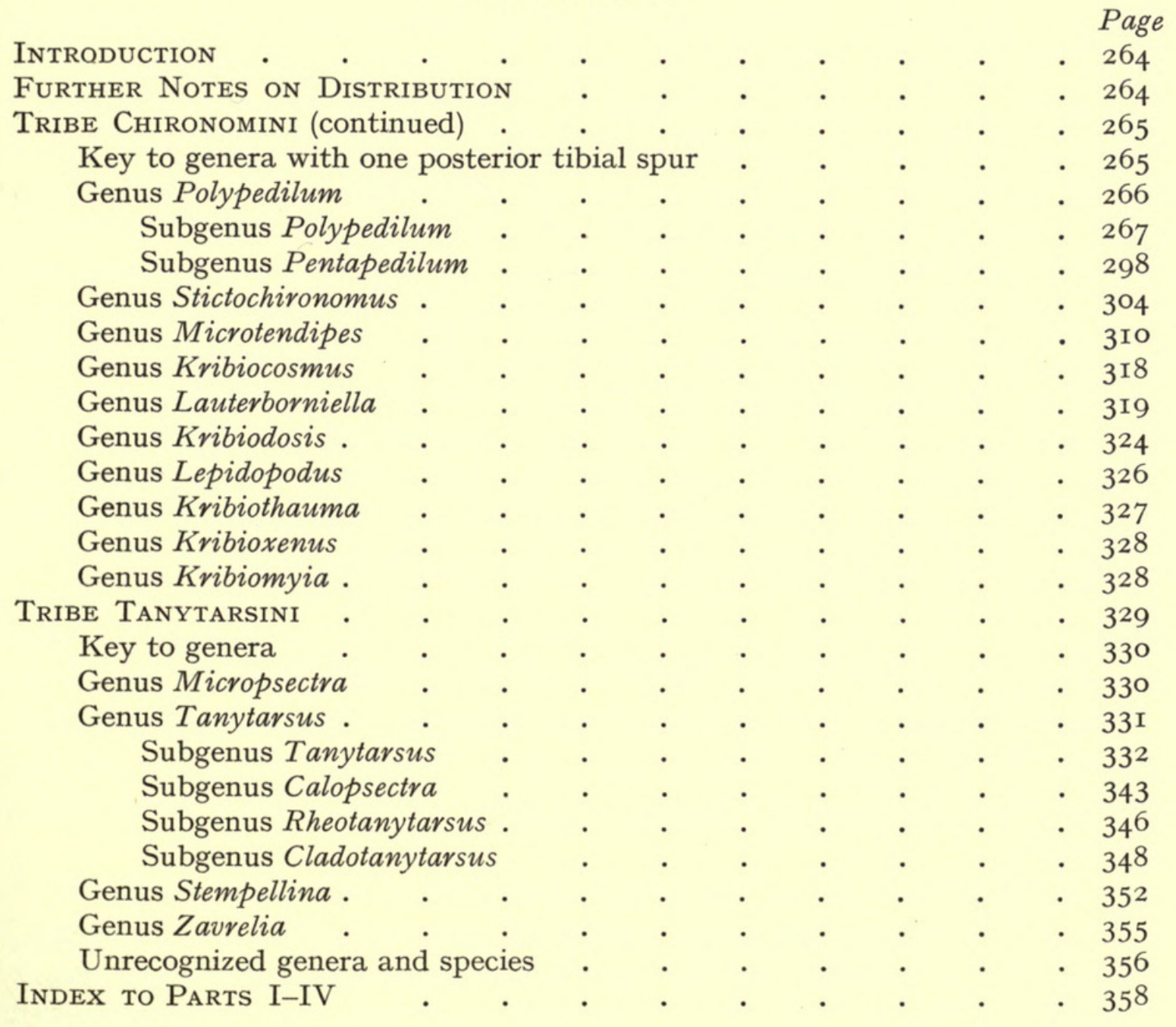

\section{SYNOPSIS}

This is the final Part of the Study of which Parts I and II were published as Nos. I and 7 of Vol. 4 and Part III as No. 9 of Vol. 5 of the Bulletin of the British Museum (Natural History) (1955-57). In Part IV the other half of the large tribe Chironomini of the subfamily Chironominae is treated together with the tribe Tanytarsini. This half of the Chironomini includes the genera that normally have only one spur on the posterior tibia, that is, Polypedilum and its allies. Part IV is of interest because it includes no less than ${ }_{5} 5$ of the 25 genera erected by 
Kieffer in I92I for African species of the Chironomini; these genera have remained virtually unknown since their description, but of the I $_{5}$ it has been possible to redescribe or synonymize I3, only two remaining quite unknown.

In accordance with the principles used in previous Parts, the large genera used by Edwards in 1929 have been broken up into smaller units, so that the classification approaches that of Goetghebuer. Eight genera are recognized in this half of the Chironomini, two more are mentioned because they have been described by Kieffer but have not been recognized, more than 60 species are described, nine being new.

In the tribe Tanytarsini four genera are used, Tanytarsus being employed with four subgenera; nearly 30 species are treated, eight being new. It is probable that further collecting of these tiny insects will add considerably to the number of species.

Additional notes are also given of the distribution of the species of the family in Africa.

\section{INTRODUCTION}

PARTS I, II and III of this Study were published as Nos. I and 7 of Vol. 4 and No. 9 of Vol. 5 respectively of the Bulletin of the British Museum (Natural History) (I955-57). A general introduction to the family with special reference to the fauna of Africa south of the Sahara (Ethiopian Zoogeographical Region) was given in Part I which also dealt with subfamilies Tanypodinae, Diamesinae and Clunioninae. In Part II the species of the subfamilies Orthocladiinae and Corynoneurinae were described, whilst Part III treated the species of the first half of the tribe Chironomini of the subfamily Chironominae, that is with the large genus Chironomus and its allies. Part IV which is the last of the series, deals with the other half of the tribe Chironomini, that is with the genera centred around Polypedilum carrying only a single spur on the posterior tibia and also with the tribe Tanytarsini.

Since publication of Part III, further large collections have been sent to me by Monsieur J. Hamon and by Messrs. A. D. Harrison and B. R. Allanson to whom I indebted for this assistance. These and other collections received previously have enabled me to add further notes on the distribution of the species.

\section{FURTHER NOTES ON DISTRIBUTION}

In Part I of these Studies, I made some tentative remarks on the geographical distribution of the species in Africa south of the Sahara. Since I wrote that Part a good deal more material has become available and has caused me to revise some of my opinions.

It appears that the bulk of the species have a very wide distribution and that, so far as I can see, there is no fauna associated especially with the Guinean Forest. Several of Kieffer's peculiar species from Kribi have been found elsewhere, outside the forest or else I have been able to recognize them as species already known to me from other areas. Good examples are afforded first by Kribiothauma pulchellum, a distinctive and easily recognized species of which I now have a male from as far away from Kribi as Great Usutu River, Transvaal and secondly Kribiocryptus viridiventris which I now know to be Chironomus (Cryptochironomus) niligenus, a species recorded from both East and West Africa.

It is probable that the distribution of the species is much more dependent on water conditions, temperature, $\mathrm{pH}$ and availability of food than on other factors. 
Presumably such light insects would be readily blown considerable distances by winds ; also river- and stream-dwelling larvae would be carried down-stream by the current, especially in flood conditions.

Additional material available to me since writing Part I numbers several thousand mounted and many tubes of spirit specimens, mainly from Cape Province, Transvaal, Belgian Congo, S. Rhodesia, Uganda, Nigeria and French West Africa. An interesting feature of it is the small number of species that are new to me and this also suggests that many of the species may have a wide distribution.

\section{SUBFAMILY CHIRONOMINAE, TRIBE CHIRONOMINI (Continued)}

The first section of this Tribe was considered in Part III of this Study; the genera included there were those containing species normally with two spurs at the apex of the posterior tibia, that is, the genera centred around Chironomus. The present Part deals with the remainder of the Tribe, that is, with the genera with only one spur on the posterior tibia, centred around Polypedilum.

Kieffer recognized I8 genera of this section with African species. Of these, I5 were described as new in keys published in I92I. He published an earlier generic key without species (I92I, Ann. Soc. sci. Brux. 40 (I) : 269-277) and a later one in the same year (I92I, Ann. Soc. ent. France, $90: 25-37$ ) as part of his series of three papers on "Chironomides de l'Afrique equatoriale". These two keys are similar but not identical; species for most of the new genera were described either in the second paper or in the succeeding two papers of the series. Virtually none of these I5 genera has since been recognized, although Goetghebuer and Edwards incorrectly placed a species of Nilothauma in Kribioxemus (see Part III) and Goetghebuer, again incorrectly, described an African species of Lauterborniella in Kribiomimus.

It is clearly important from the point of view of the study of the Chironomidae as a whole to rediscover these genera and to redefine or synonymize them where necessary. I have been able to recognize $\mathrm{I} 3$ of them and in Table I, I am listing all I5 with their position or probable position in this Study. I am giving such diagnoses as are possible for the two unidentified genera Kribioxenus and Kribiomyia.

\section{Key to African Genera of Tribe Chironomini}

SeCtion II : genera regularly with only one spur on posterior tibia.

I. Squama bare ; femora often swollen apically to form a slight club $\quad$. $\quad$. $\quad$. 2 Squama fringed ; femora only swollen apically in Lepidopodus . $\quad$. $\quad$. $\quad$. 3

2. Pulvilli well developed; antenna of female with 6-7 segments; VIIIth abdominal segment of male not contracted basally . . . . . Lauterborniella Bause

Pulvilli scarcely distinguishable ; female antenna with 5 segments ; VIIIth segment of male contracted basally . $\quad . \quad$. $\quad . \quad$. $\quad . \quad$. Kribiodosis Kieffer

3. Wing membrane with macrotrichia at least at the apex

Wing membrane quite bare of macrotrichia

Polypedilum subg. Pentapedilum Kieffer

4. Anterior tibial scale armed with a spur

Anterior tibial scale quite unarmed. 
5. Anterior tibial spur strong and usually curved; pulvilli either absent or inconspicuous; VIIIth abdominal segment of male not constricted basally . .

Scale either triangular and with a sharp point or oval and with a short spur at the apex, rarely with a longer spur; pulvilli conspicuous, each split longitudinally (only visible in slide mounts); VIIIth segment of male constricted basally

6. Wings plain .

Polypedilum Kieffer

Wings with dark pattern .

7. Wings broad, posterior fork short (Pl. 2, fig. $r$ ); male antenna with all segments approximately equal, plumes absent (Text-fig. 9, c) . . . Kribiothauma Kieffer Wings of normal shape, fork below cross-vein (Pl. 2, fig. $m$ ) ; male antenna normal, A.R. about 0.6 . . . . . . . . Kribiocosmus Kieffer

8. Prothorax reduced centrally but produced laterally as a short tubercle ; legs long and slender, clothed with adpressed scales as well as erect bristles. Lepidopodus gen. nov.

Prothorax not like this; legs without scales

9. Prothorax much reduced, head overhung by mesonotum; acrostichal bristles reduced to a group at the apex of the mesonotal cone, no central mesonotal tubercle . . . . . . . . . . Microtendipes Kieffer

Prothorax less reduced; acrostichal bristles either as a complete double row or quite absent; mesonotum often with a central tubercle

Stictochironomus Kieffer and ? Kribiomyia Kieffer

TABLE I.-Single-spurred Genera Described by Kieffer in I92 I from African Species

Genus

\begin{tabular}{|c|c|}
\hline Kribiothauma & \\
\hline Kribiodosis & \\
\hline Kribiodorum & . \\
\hline Tripedilum & . \\
\hline Kribiocosmus & • \\
\hline Kribioxenus & 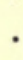 \\
\hline Kribiomimus & $\cdot$ \\
\hline Kribiocharis & • \\
\hline Kribionympha & . \\
\hline Kribiocallis & \\
\hline Kribiomyia & \\
\hline Kribiotima & \\
\hline Kribiophilus & \\
\hline Rosenia . & t \\
\hline Kribiopelma & • \\
\hline
\end{tabular}

Position in present Study

Valid genus of uncertain affinities.

Valid genus allied to Lauterborniella.

Synonym of Lauterborniella.

Synonym of Polypedilum.

Valid genus.

Not identified.

Synonym of Microtendipes.

Synonym of Polypedilum.

Synonym of Polypedilum.

Synonym of Stictochironomus.

Not identified.

Probably two names for the same genus (q.v.);

synonym of Polypedilum.

Synonym of Polypedilum subg. Pentapedilum.

? Synonym of Polypedilum subg. Pentapedilum.

\section{Genus POLYPEDILUM Kieffer}

Polypedilum Kieffer, I913, Bull. Soc. Hist. nat. Metz, 28 : I5.

Pentapedilum Kieffer, 1913, ibid. $28: 25$.

Chironomus subg. Polypedilum Edwards, 1929, Trans. ent. Soc. Lond. 77 : 401.

Pentapedilum subg. Pentapedilum Edwards, 1929, ibid. 77 : 376.

Antennae of male with I4 segments, of female with 6 segments; frontal tubercles only occasionally present. Pronotum moderately developed, usually not visible from above, mesonotum without a central hump or tubercle (see Stictochironomus) 
both acrostichal and dorso-central bristles well developed and long. Front tibial scale either triangular and sharply pointed or else oval and with a small but definite spur, rarely with a longer spur ; outer comb of posterior tibia and posterior comb of middle tibia each with a single spur which is usually quite long, the other comb of each leg is large and simple; combs not fused; pulvilli each split longitudinally into two narrow lobes, so that with the empodium there appear to be five processes below the tarsal claws (only visible in slide mounts). Wing membrane with or without macrotrichia and either unmarked or with well-formed dark clouds and spots ; squama with complete fringe ; $R_{2+3}$ ending not far beyond tip of $R_{1}$, posterior fork slightly or considerably beyond $\mathrm{r}-\mathrm{m}$. Eighth abdominal segment of male constricted basally so as to appear triangular; anal point well developed, appendage 2 usually with a long terminal hair, styles of variable shape.

In his I929 paper on the British species of the family, Edwards treated Polypedilum as a subgenus of Chironomus and Pentapedilum as a separate genus to include all the hairy-winged groups outside the Tanytarsini. In I93I (Dipt. Pat. S. Chile, 2:3I0) he revised his opinion about Pentapedilum, realizing that the included groups were not really closely allied and he restricted the name to the group treated as subg. Pentapedilum in his I929 work.

Species of Pentapedilum in this restricted sense are extremely similar to species of Polypedilum, differing only in the presence of macrotrichia on the wing membrane. As pointed out by Edwards this is not always a good character by any means, and the African species bear out this view, one species having hair at the extreme wing apex only. I do not agree with Edwards that both Polypedilum and Pentapedilum should be considered as equal subgenera of Chironomus but I prefer to follow Townes (I945, Amer. midl. Nat.34:36) and place both as subgenera of the genus Polypedilum. Townes's third subgenus Tripodura is discussed under the subgenus Polypedilum.

Polypedilum is one of the better defined genera of the family. In doubtful cases examination of the pulvilli and eighth segment of the male abdomen affords ready means of determining the genus. As I have previously pointed out, Edwards (I929) denied the presence of split pulvilli, but these can be seen in slide mounts under high magnification and have been figured by Townes (I945). It is a very abundant genus in Africa south of the Sahara.

\section{Key to Subgenera of Polypedilum}

Macrotrichia present on wing membrane at least at apex of cell $\mathrm{R}_{4+5}$; wings without dark markings . . . . . . . . . . . . Pentapedilum Kieffer Macrotrichia entirely absent from wing membrane; wings frequently with conspicuous dark markings

Polypedilum Kieffer

\section{Polypedilum Kieffer Subgenus Polypedilum sensu stricto}

Polypedilum Kieffer, 1913, Bull. Soc. Hist. nat. Metz, 28 : I5; Kieffer, I9г3, Voy. All. Jean. Afr. Or. Ins. Dipt. 1:21 ; Kieffer, 1918, Ann. Mus. nat. Hung. 16:65; Kieffer, I921, Ann. Soc. sci. Brux. 41 (I) : 97 (in part) ; Kieffer, 1922, Ann. Soc. ent. France, 91 : r9 ; Kieffer, 1925, Bull. Soc. R. ent. Égypte, 1924: 265; Goetghebuer, 1936, Rev. Zool. Bot. Afr. 28:480; Goetghebuer, 1937, in Lindner, Flieg. Pal. Reg. 3 (13c) : 56; Townes, 1945, Amer. midl. Nat 34: 36 ; Freeman, 1955, Explor. Parc Nat. Albert, Miss. G. F. de Witte, fasc. 83 : 25. 
Chironomus Kieffer, r9ı1, Trans. Linn. Soc. Lond. (Zool.) 14:35I (in part); Kieffer, r9r8, Ann. Mus. nat. Hung. 16:66 (in part).

Paratendipes Kieffer, 1913, Voy. All. Jean. Afr. Or. Ins. Dipt. 1:24 (not Kieffer, r9ı1, Bull. Soc. Hist. nat. Metz, $28: 4 \mathrm{I})$.

Tripedilum Kieffer, I921, Ann. Soc. sci. Brux. 40 (I) : 271 ; Kieffer, I921, Ann. Soc. ent. France, $90: 28$ and 47 (SYN. NOv.).

Kribiomimus Kieffer, I921, Ann. Soc. sci. Brux. 40 (I):271; Kieffer, I921, Ann. Soc. ent. France, $90: 29$ and 49 (in part).

Kribionympha Kieffer, I92I, Ann. Soc. sci. Brux. 40 (I):271 ; Kieffer, I921, Ann. Soc. ent France, $90: 29$; Kieffer, I922, ibid. $91: 7$ (sYN. Nov.).

Kribiotima Kieffer, I921, Ann. Soc. sci. Brux. 40 (I) : 274 (syn. nov.).

Pentapelma Kieffer, I92I, ibid. 41 (I) : 98 (? not Kieffer, I921, ibid. 40 (I) : 274 and I92 I, Ann. Soc. ent. France, $90: 33)$.

Kribiophilus Kieffer, I921, ibid. $90: 30$ and I922, ibid. 91:43; Kieffer, I921, Ann. Soc. sci. Brux. 41 (I) : 98 (SYN. NOv.).

Kribiocharis Kieffer, 1922, Ann. Soc. ent. France, 91 : I (in part).

Microtendipes Kieffer, 1922, ibid. $91: 8$ (not Kieffer, 1915, Broteria, Sér. Zool. 13 : 70).

Chironomus subg. Polypedilum Edwards, 1929, Trans. ent. Soc. Lond. $77: 401$.

Polypedilum subg. Tripodura Townes, 1945, Amer. midl. Nat. $34: 36$.

This, the typical subgenus, differs from Pentapedilum solely by the absence of macrotrichia on the wing membrane.

Kieffer appears to have depended almost entirely on the condition of the pulvilli for generic determination of species of Polypedilum and, because this is a most difficult character to see without special preparation, he seems often to have made mistakes. For instance, after examination of type specimens, I have found that he placed Polypedilum alticola in Polypedilum in I9I3, but that he redescribed it in I9I8, this time in Chironomus. Having realized this, it became possible to identify not only several of his species of Polypedilum which he had placed in the wrong genera, but also to place in synonymy the genera Tripedilum (type armatifrons monobasic) and Kribionympha (type declivis monobasic). Tripedilum armatifrons was described from two females with frontal tubercles and is the same species as he later described as Polypedilum longiforceps from the male; both fall as synonyms of $P$. fuscipenne. It is interesting to see that although he mentioned the prominent frontal tubercles in the former, he omitted them in the latter, but the figure of the male hypopygium renders longiforceps easily identifiable. Kribionympha declivis is a very similar species, the pulvilli are split and the eighth segment of the male abdomen is narrow basally.

I was in error in I955 in placing Kribiocharis as a synonym of Microtendipes; Kieffer's mention of the triangular eighth segment of the male abdomen makes it clear that the type species (K. filitarsis fixed by me in I955) is a species of Polypedilum similar to and probably identical with $P$. tenuitarsis.

Kieffer was rather confused in his use of the two genera Kribiotima and Kribiophilus. The former was described (Ann. Soc. sci. Brux. 40 (I):274) in a key, no included species were given and so far as I can discover, the genus was not mentioned by him in print again. In his I92I-23 series of papers (Ann. Soc. ent. France, 90-92) the place of Kribiotima in the key is taken by Kribiophilus, for which there are two described species neither being fixed as the type of the genus. There is in 
the British Museum a postcard written by Kieffer to W. L. Sclater on 5 th September, I923 on which he says that Kribiophilus (type pictipennis) is a subgenus of Kribiotima. Again in I92I (Ann. Soc. sci.Brux. 41 (I) : 98), he refers to Kribiophilus but this time as a subgenus of Polypedilum.

It seems probable that Kribiotima was an earlier name and Kribiophilus a later name for the same genus and that the latter is to be regarded as a synonym and not a subgenus of the former. I hereby fix $K$. pictipennis Kieffer, I922 as type of the genus Kribiophilus. Because this is a redescription of Polypedilum quinqueguttatum Kieffer, Kribiophilus automatically falls as a synonym of Polypedilum. There is no discernible difference between Kribiophilus and Kribiotima, both being separated from Polypedilum according to Kieffer by the greater width between the eyes, and so Kribiotima also falls as a synonym of Polypedilum.

Pentapelma was originally described by Kieffer in June I92I (Ann. Soc. sci. Brux. 40 (I) : 274) as a genus with hairy wings belonging to "Groupe Tanytarsus". No type was fixed but in a paper published on I4th December, I92I (Ann. Soc. ent. France, $90: 33$ ) he fixed zavreli Kieffer. However, two days before this, on I2th December, I92I another paper of his was published (Ann. Soc. sci. Brux. 41 (I) : 98) in which Pentapelma was used as a plain-winged subgenus of Polypedilum with integrum Kieffer as type of the subgenus. Later authors have followed this interpretation, but whichever is followed both appear to be synonyms, the division of Polypedilum on wing colour not being valid.

Kieffer (I922, Ann. soc. ent. France, $91: 8$ ) used Microtendipes for ten species with pointed or spurred scale to the anterior tibia, a character unknown in the species of that genus as it is understood now. Those of the ten that I have been able to identify are species of Polypedilum and it is likely that the remainder belong here as well, but as only three were described from males it is difficult to be certain. I am treating them as species of Polypedilum until there is evidence that they belong to other genera.

Townes (1945, Amer. midl. Nat. 34:36) erected the subgenus Tripodura for the group of species with lateral teeth to the anal point (" trifid ") and with appendage I broad. There seems to be too much variation and intergrading for this subdivision to be accorded subgeneric rank and I am accordingly regarding it as a synonym.

The genus cannot easily be subdivided into subgenera although quite well marked species groups can be seen. The division into those with plain wings and those with patterned wings is not valid because of the existence of species, such as tridens, with plain wings having their most obvious allies amongst species with strongly patterned wings.

Many of the species of Polypedilum are common and widespread, they are also subject to a good deal of variation. That this variation is infraspecific is fairly certain from study of species with distinctive features such as griseoguttatum or ramiferum. In each of these two species the male hypopygium is of an unusual form and the wing markings are also rather different from those of most other species. In griseoguttatum there is variation from locality to locality in the shape of the markings in cell $R_{5}$ and in the development of the lateral teeth at the base of the anal point as well as in the number of hairs on appendage 2. In ramiferum the 
male hypopygium shows some differences in the shape of the parts, but the main variation lies in leg colour and intensity of wing markings. A number of the species of Kieffer and Goetghebuer have been described from varieties of this type and by realizing the plastic nature of the wing markings of many species I have been able not only to arrive at a better understanding of the limits of a given species but also to synonymize many of the older names.

Seventy species have been described in Polypedilum from Africa south of the Sahara and from Egypt, but three from Egypt seem to be Palaearctic in distribution and have been omitted ; in addition Kieffer has described in other genera a number of species really belonging to Polypedilum. In particular, as mentioned above, he seems to have been confused between Polypedilum and Microtendipes in his I92I-23 papers. Of the 67 described in Polypedilum, 13 do not belong there and others are redescriptions of previously described species.

In the material at my disposal, I am able to recognize 36 species of which four are new. Into the 32 species that are not new, a very high proportion of the previously described species can be fitted either as valid species or as synonyms, but there still remain one species of Paratendipes, five of Polypedilum and five of Microtendipes described by Kieffer mostly from females which I am unable satisfactorily to place. These are as follows :

Polypedilum lumiense and Paratendipes tavetanus I9r3, Voy. All. Jean. Afr. Or. Ins. Dipt. 1:2I-22. The type series of these are in the Paris Museum, but being small plain winged females it is not possible to assign them to one of the species described below. Type locality of both KenYa : Taveta.

Polypedilum leucolabis I922, Ann. Soc. ent. France, $91: 22$. Described from a male with plain wings; the hypopygium is white, appendage I narrow and curved, appendage 2 bilobed at the extremity. Type locality French Cameroons; Kribi.

Polypedilum nymphella I922, ibid. $91: 26$. Described from a small female which was separated from other species mainly by being entirely whitish and is probably unrecognizable. Type lost, locality Kribi.

Polypedilum distans I922, ibid. 91:27. Again described from a pale female (length $2.5 \mathrm{~mm}$.) with plain wings, but as the scale of the anterior tibia is rounded it may not belong to this genus at all. Type lost, locality SudAN : Shambe.

Polypedilum pumilio I922, ibid. $91: 28$. The small male from which this was described (length $\mathrm{I} \cdot 5 \mathrm{~mm}$.) was separated from distans by the mouthparts equalling only half the height of the head; hypopygium simple, appendage I curved and narrow Type lost, locality Kribi.

Microtendipes magnipennis, pilosicornis, truncatus kribiensis and calcaratus I922, ibid. 91 : I2-I4. All were described from females from Kribi and were separated from each other by minor structural points ; they may well be females of species of the group of Polypedilum fuscipenne and longinervis. All the types are lost.

\section{Key to African Species of Polypedilum Subgenus Polypedilum}

I. Wings patterned, usually boldly marked with dark spots and clouds, in a few species markings faint but distinguishable in cell $R_{5}$ or at cross-vein and posterior fork . Wings without markings in any of the cells 
2. Wing markings very faint (Pl. I, figs. $c, k)$; occasional specimens of quinqueguttatum have very pale spots and can be recognized by the male hypopygium

Wing markings bold

3. Three faint spots in cell $\mathrm{R}_{5}$; anal point not trifid (Text-fig. $\mathrm{I}, b$ ) . Faint clouds in base only of cell $\mathrm{R}_{5}$ and over $\mathrm{Cu}$

4. Anal point trifid (Text-fig. 2,e) Anal point simple (Text-fig. $2, f$ )

5. Wings with a discrete dark spot in basal cell, basal to cross-vein (e.g. Pl. I, figs. $f, l$ ) Wings lacking a dark spot here although there may be general clouding

deletum Goetghebuer

6. Cell $\mathrm{R}_{5}$ with three spots of variable shape (Pl. I, figs. $l-o$ ) griseoguttatum Kieffer Cell $R_{5}$ with two spots only

7. Base of cell $\mathrm{R}_{5}$ clear (Pl. I, fig. $f$ ) Base of cell $\mathrm{R}_{5}$ with a dark spot (Pl. I, fig. $h$ )

8. Wing very dark or blackish with clear spots (Pl. I, fig. $r$ ) Wing much paler, pattern different .

9. Base of cell $\mathrm{R}_{5}$ with a large clear area (Pl. I, figs. $d-e$ ) Base of cell $R_{5}$ occupied by a dark spot

ro. Wing markings as in $\mathrm{Pl}$. I, fig. $d$, cross-vein clouded Wings with cross-vein clear (Pl. I, fig. $e$ )

- aegyptium Kieffer . subovatum sp. $\mathrm{n}$.

Io $a$. Anal point of male simple (Text-fig. I, $e$ ); tract in cell $\mathrm{M}_{2}$ entire (Pl. I, fig. $e$ )

Anal point trifid; tract broken into two spots

annulatipes Kieffer allansoni $\mathrm{sp} . \mathrm{n}$.

II. Basal third of cell $\mathrm{R}_{5}$ occupied by a large dark conspicuous mark (Pl. I, fig. $a$ ) ; a large dark species

The spot in this position much smaller

12. Abdominal segments with pale apical rings, wings as in Pl. I, figs. $p, q$. alticola Kieffer

Abdominal segments without pale rings

13. Legs with yellow and black markings on tibiae and tarsi ; wings as in Pl. I, fig. $p$; male styles with long plumose hairs (Text-fig. 3, a) .

. ramiferum Kieffer

Legs without these markings ; wings as in Pl. I, fig. $q$; style hairs simple, appendage I reduced (Text-fig. $3, b$ )

albosignatum Kieffer

I4 Wing length $2.5 \mathrm{~mm}$. or more, large dark species, wing pattern as in Pl. I, fig. $b$ ) ; male hypopygium similar to alticola (Text-fig. $\mathrm{I}, a) . \quad . \quad . \quad$. natalense Kieffer

Wing length $\mathrm{I} \cdot 5 \mathrm{~mm}$. or less, very small species .

15. Cell $\mathrm{R}_{5}$ with three dark markings (Pl. I, fig. $j$ ) ; male hypopygium as in Text-fig. $2, d$

Cell $\mathrm{R}_{5}$ with only two dark spots

pruina Freeman

I6. Wings with dark spots below apices of veins $\mathrm{M}_{1+2}$ and $\mathrm{M}_{3+4}$ (Pl. I, fig. $g$ ); anal point of male very fine (Text-fig. 2, $a$ ), not trilobed .

Wing markings without these spots (Pl. I, fig. $i$ ) ; anal point broad and with lateral spines making it appear trifid (Text-fig. 2,c) . . . . . . tropicum Kieffer

I7. Well-developed frontal tubercles present . . . . . . . . . . . . . $\quad$ I8

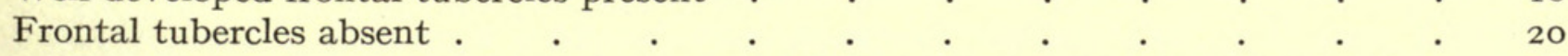

I8. L.R. more than 2 ; thorax mainly pale or reddish ; male front tarsi not bearded . I9 L.R. about I.I ; thorax black; male front tarsi bearded . . lobiferum Freeman

19. Scale of front tibia short and black, spur long and black; male styles long (Textfig. $3, d)$.

fuscipenne Kieffer

Scale of front tibia longer and yellow, spur very short and dark; male styles more or less oval (Text-fig. $3, e$ )

20. Eyes practically touching above; anterior tibiae black declivis Kieffer Eyes separated by at least the apical width of the narrow portion subconfluens Kieffer

2I. Thorax pale but with a strongly marked dark lateral stripe on the pleuron $2 \mathrm{I}$ If thorax pale then pleuron without obvious dark stripe 
22. Larger species, wing length $2-3 \mathrm{~mm}$., cross-vein long; appendage I of male hypopygium bilobed (Text-fig. $3, g$ )

longinervis Kieffer

Very small species, wing length $\mathrm{I} \cdot 6-8 \mathrm{~mm}$., cross-vein normal; appendage I not bilobed

laterale Goetghebuer

23. Segments $\mathrm{I}-5$ of abdomen yellow with a saddle-shaped black spot on segment 3 , thorax and segments $6-8$ black

- ephippium sp. n.

Abdomen not like this, if it is pale then there is no black spot on segment 3 only $\quad$. $\quad 24$

24. Thorax and abdomen black . . . . . 25

Thorax and abdomen at the most brown, usually paler $\quad . \quad$. $\quad$. $\quad . \quad 2 \quad 27$

25. Small species, wing length $\mathrm{I} \cdot 5 \mathrm{~mm}$., anal point trifid (Text-fig. 2, g) . tridens Freeman

Larger, wing length 2-3 mm., anal point simple .

26. Halteres black

Halteres pale .

27. Thorax yellowish and with a pair of circular black spots at enterior ends of lateral stripes

Thorax without these spots

28. Appendage I of male hypopygium broad (Text-fig. $4, d$ )

Appendage I narrow (Text-figs. $4, a, e, g$ ) .

29. Abdomen pale, sometimes with narrow dark rings at apices of segments

Abdomen dark with pale rings at apices of segments .

kibatiense Goetghebuer annulatum Freeman

3o. Halteres black

Halteres pale .

3I. A.R. of male I 6 , styles wider (Text-fig. $4, e$ )

A.R. only 0.5 , styles narrower (Text-fig. $4, g$ )

melanophilus Kieffer and glabripennis Kieffer

32. Front tibial scale with short spur; colour pale brown

Front tibial spur black and as long as the scale ; colour darker brown

vanderplanki Hinton

33. Appendage I of male hypopygium strongly curved and with a narrow apex (Text-

fig. $4, a)$

bifalcatum Kieffer

Appendage I similar to brunneicornis (Text-fig. 4,e) . . . dewulfi Goetghebuer

\section{Polypedilum (Polypedilum) alticola Kieffer}

Polypedilum alticola Kieffer, 1913, Voy. All. Jean. Afr. Or. Ins. Dipt. 1:22; Freeman, 1955, Explor. Parc Nat. Albert, Miss. de Witte 83: 26; Freeman, 1955, S. Afr. Animal Life. Uppsala, $2: 377$.

Chironomus ornatipennis Kieffer, 1918, Ann. Mus. nat. Hung. 16:68 (syn. Nov.).

A large dark species with strongly marked wings. It is readily recognized by the large dark spot which fills the basal quarter or third of cell $R_{5}$; male styles very bulky, hypopygium similar to natalense. It is a species found especially in mountainous regions but in South Africa there are specimens more or less intermediate between it and natalense suggesting that the two may only be forms of each other.

Male. Wing length 3-4.5 mm.

Head and mouthparts blackish, antennae brown, A.R. about I.5, frontal tubercles absent. Thorax blackish or dark brown, dorso-central and acrostichal bristles strongly developed and pale, lines of hairs and thoracic margins pruinose. Legs yellowish or brownish, femora may be darker, anterior tibia subequal to femur, L.R. about $I \cdot 4$, scale triangular and with tiny spur, tarsus not bearded. Wings 
(see Pl. I, fig. $a$ of female) strongly marked and clouded, although not as strongly as in the female; the most conspicuous spots are in cell $R_{5}$, the basal one occupying sometimes a third of the cell and usually at least a quarter, other markings more vague; some specimens from Cape Province and Natal, have the basal mark in cell $\mathrm{R}_{5}$ smaller than usual and the other markings more discrete, thus approaching the condition seen in natalense; halteres with black knobs and pale stems. Abdomen black, apices of segments or sometimes whole incisures pale; hypopygium (Textfig. I, $a$ ) with bulky styles, appendage I and anal point both narrow, exactly similar to natalense.

Female resembles male; wing markings more intense, abdomen may have more extensive pale markings, especially laterally.

I have seen cotypes of alticola in Muséum National d'Histoire Naturelle, Paris (type locality Kenya : nr. Fort Hall) and also the type male of ornatipennis which was in the Hungarian National Museum (Natal: New Hanover).

Distribution. Cape Province: 2 ô, Berg R., Assegaibos, ii.I953 (K. M. F. Scott). Natal: I ô, Kloof, ix.I926 (R. E. Turner); I ô, 5 오 Natal National Park, iii.I932 (A. Mackie); 6 ô, 2 ㅇ, Estcourt, ix.I953 (A. D. Harrison). TransvaAl : 5 ô, nr. Lydenburg, v.I95I (P. Brinck). S. Rhodesia : I ô, Umtali, iv. I929 (A. Cuthbertson). Angola: I + , Benguela (L. Massey). Tanganyika: I 우 Njombe, 6,000 ft., ii. I95I (W. Peters). Belgian Congo: I02 우, Parc. Nat. Albert (de Witte); I 오 V. Karissimbi, Nya Muzinga, i.I926 (H. Schouteden). Kenya : 4 ô, Kabete (R. H. Deakin) and 5 우․ xi.I9I3 (T. J. Anderson); 2 oै, Nairobi, v.I927 (Symes \& Hopkins) ; I 오 Solai Distr., Sonje V., ix. IgI9 (T. J. Anderson) ; II ô, Mt. Elgon, Heath Zone, I0,500-II,500 ft., ii.I935 (F.W. Edwards) ; I , Mt. Kinangop, Aberdare Range, 8,00o ft., x.I934 (F.W. Edwards). Eтнiopia : 2 ô, Bahrdar, x-xi.I952 (G. Covell) ; 2 ㅇ, Dessie, xii.35-i.36 (J.W. S. Macfie); I , Waldia, i.I936 (J.W.S. Macfie) ; I ô, I + , Alamata, iii.I936 (J.W. S. Macfie); I ô, Koram, iii.I936 (J.W.S. Macfie). Sudan : 5 ô, 48 우, W. Darfur, Jebel Murra, Killing, 7,000 ft., vi.I932 (M. Steele).

\section{Polypedilum (Polypedilum) natalense Kieffer}

Chironomus natalensis Kieffer, I918, Ann. Mus. nat. Hung. 16:67.

Polypedilum brevistilum Freeman, 1954, Proc. R. ent. Soc. Lond. (B) 23 : 178 (syn. Nov.).

Similar to alticola in general appearance and structure, wing length $2 \cdot 5-2 \cdot 75$ mm., thorax more generally pruinose, abdomen without pale rings at the incisures, but sometimes paler laterally; hypopygium similar to alticola. The main difference between the two lies in the wing markings which are much more restricted and discrete in natalense (Pl. I, fig. b). As stated under alticola there are specimens of that species with wing markings approaching those of natalense suggesting that the two may be forms of one species, but longer series and more distributional data are necessary before it is possible to decide this.

I have seen the holotype male of natalense which was in the Hungarian National Museum (type locality Natal: New Hanover). The holotype male of brevistilum is in the British Museum (CAPE Province : Berg River). 
Distribution. Apart from the holotypes and other specimens from the type localities of Cape Province, Natal and Belgian Congo: Elisabethville, I have seen: Transvaal: I 옹 Pongola R. Settlements, ix.I954 (A. D. Harrison); 2 ㅇ, Lydenburg, ix.I954 (A. D. Harrison). S. Rhodesia: I 옹 Salisbury, v. I956 (E. T. M. Reid). Nyasaland : I $\widehat{o}$, Langenburg (Füllerborn).

\section{Polypedilum (Polypedilum) deletum Goetghebuer}

Polypedilum deletum Goetghebuer, 1936, Rev. Zool. Bot. Afr. $28: 483$; Freeman, 1955, S. Afr. Animal Life. Uppsala, 2 : 377.

Polypedilum obsoletum Goetghebuer, 1936, Rev. Zool. Bot. Afv. $28: 488$; Freeman, 1955, Explor. Parc Nat. Albert, Miss. de Witte, $83: 27$ (syn. nov.).

Blackish or very dark brown, legs pale, halteres black, wings with three faint grey spots in cell $R_{5}$ and with veins more or less seamed with grey; male styles swollen, anal point and appendage I simple. Although the wing markings are much paler than in alticola, their positions are similar and the male genital structure also bears a resemblance.

Male. Wing length $2-3 \mathrm{~mm}$.

Head and mouthparts black or very dark brown, frontal tubercles absent, antennae brown, A.R. about 2. Thorax blackish or very dark brown, slightly pruinose, bristles dark, scutellum sometimes paler; pruinosity of hair lines and of stripes changeable. Legs yellow, femora sometimes darker, tarsal beard absent, L.R. $\mathrm{I} \cdot 75$, anterior tibial scale oval and with a short colourless spine. Wings (Pl. I, fig. c) practically hyaline but with faint grey spots in the base, near the middle and at the apex of cell $R_{5}$; veins, especially fork veins, more or less grey seamed or clouded. Halteres with black knobs. Abdomen black or dark brown, without pale bands; hypopygium (Text-fig. I, $b$ ) with styles swollen but less so than in alticola, anal point and appendage I narrow.

Female resembles male.

I have seen the holotypes of both species ; deletum is clearly the male (BELGIAN Congo: Vitshumbi) and obsoletum the female (UGAnda: Namasagali) of the same species; both are in Musée Royal du Congo Belge, Tervuren.

Distribution. Gold CoAst: 2 ㅇ, Red Volta, Nangodi, x.I954 (G. Crisp). Nigeria : 2 , Kankiya (B. McMillan). Uganda : 2 ô, Jinja, i. I956 (P. S. Corbet). Belgian Congo : series from Parc Nat. Albert and from Kivu ; $2 \hat{0}, 5$ 옹 Elisabethville, xii. 938 (H. J. Brédo). S. Rhodesia : 8 ô, Salisbury, v.I956 (E. T. M. Reid).

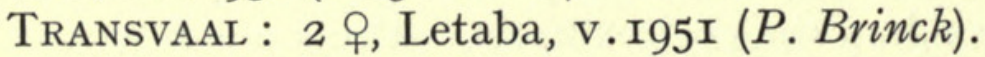

\section{Polypedilum (Polypedilum) fuscum Freeman}

Polypedilum fuscum Freeman, 1954, Proc. R. ent. Soc. Lond. (B) 23 : 177.

A medium-sized black species, very similar to deletum, from which it may be separated by the wing markings and possibly by the male genital structures. The wings have no distinct spots but the veins are seamed with grey and there is a grey longitudinal shadow just discernible in cell $R_{5}$ running the complete length of the 
cell just behind vein $\mathrm{R}_{5}$; halteres black. Male hypopygium (Text-fig. I, $c$ ) with styles more pointed than in deletum and with proportions of parts slightly different, but this may be variable. Whether this species and the following one are really distinct from deletum is not certain, but until more is known of the range of variability it is convenient to maintain them as separate species.
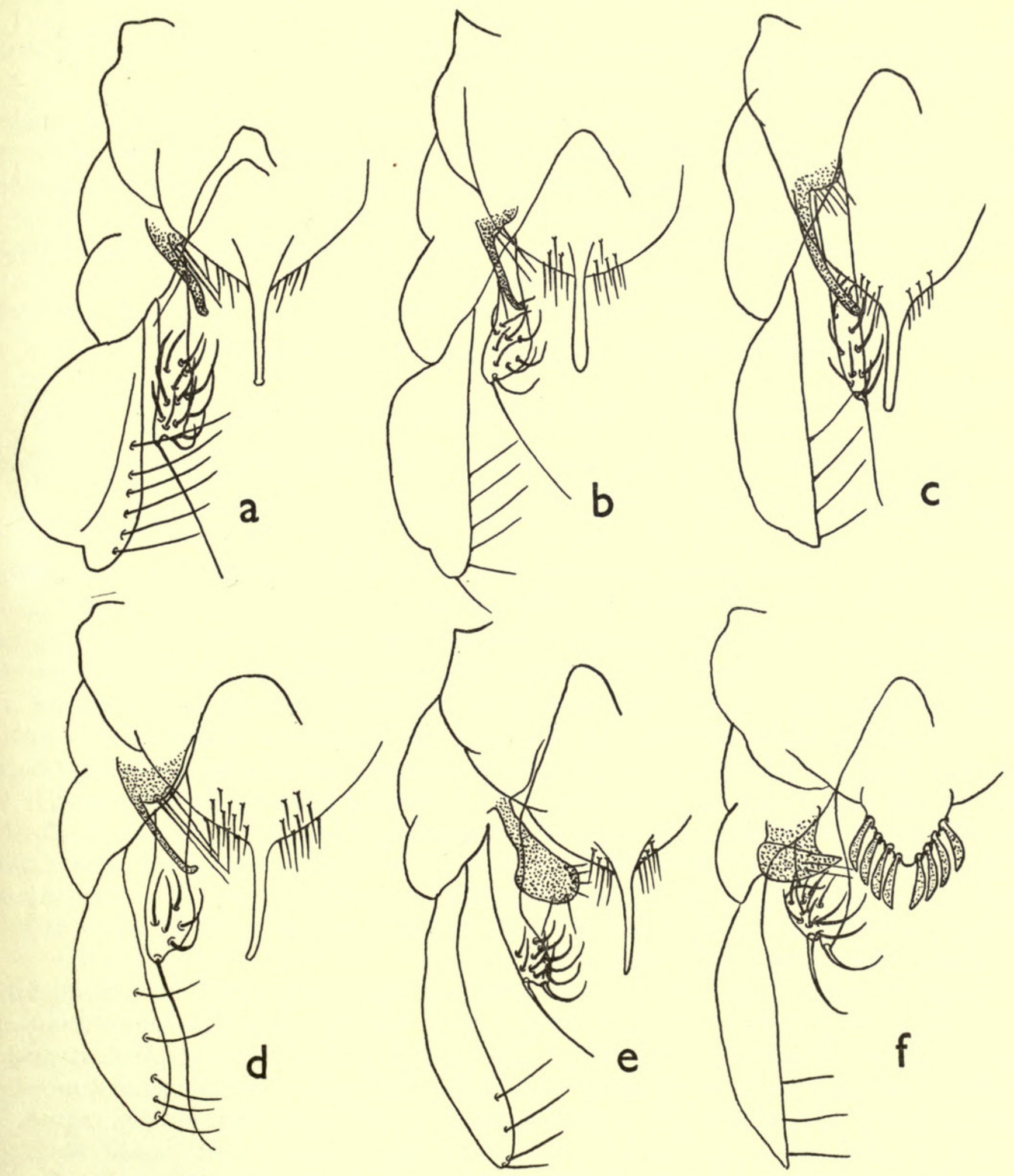

FIG. I. Male hypopygia of Polypedilum (Polypedilum). (a) P. alticola; (b) P. deletum; (c) P. fuscum; (d) P. tenuitarsis ; (e) P. annulatipes; $(f)$ P. abyssiniae. 
Holotype male in the British Museum (type locality CAPE Province: Hermanus Waterfall).

Distribution. Apart from the type series, I have seen: Transvaal: I 우, Nelspruit, ix.I954 (A. D. Harrison); I ô, Sabie-Pilgrim's Rest Road, ix.I954 (A. D. Harrison).

\section{Polypedilum (Polypedilum) incoloripenne Goetghebuer}

Polypedilum incoloripenne Goetghebuer, 1936, Rev. Zool. Bot. Afv. 28:486; Freeman, 1955, Explor. Parc Nat. Albert, Miss. de Witte, $83: 27$.

As with fuscum, this species is very similar to deletum in structure and general appearance. It may be distinguished from both by the absence of all wing markings and by the pale halteres; male hypopygium with styles more pointed as in fuscum and proportions more as in that species.

I have seen the holotype male in Musée Royal du Congo Belge, Tervuren (type locality Belgian Congo: Rutshuru).

Distribution. The only other specimens known to me are from Belgian Congo: Lac Magera (de Witte).

\section{Polypedilum (Polypedilum) tenuitarsis Kieffer}

Kribiomimus leucolabis Kieffer, I921, Ann. Soc. ent. France, 90 : 50 (not Polypedilum leucolabis Kieffer, I92I, Ann. Soc. sci. Brux. 41 (I) : 98) (syn. Nov).

? Kribiocharis filitarsis Kieffer, 1922, Ann. Soc. ent. France, 91 : 2.

Kribiocharis tenuitarsis Kieffer, I922, ibid. $91: 6$.

Polypedilum fenestratum Goetghebuer, 1936, Rev. Zool. Bot. Afr. 28:485; Freeman, I955,

S. Afr. Animal Life. Uppsala, $2: 376$ (syn. Nov.).

A small pale species with strongly marked wings; thorax yellowish with stripes hardly darker, pleura with a dark stripe, abdomen darker but apices of segments pale, wing markings more or less in form of two bands with an oval clear area at base of cell $R_{5}$ and another in fork cell, apex also darkened. Although the types are lost, Kieffer's descriptions of leucolabis and tenuitarsis leave no doubt that both are earlier descriptions of fenestratum; $K$. filitarsis is more doubtful, although it is certainly a Polypedilum because of the triangular eighth segment and closely resembles this species, and I prefer to leave it as a query synonym. The name leucolabis is preoccupied by a species published two days earlier; I prefer not to follow page precedence but to use the more certain name for the species.

Male. Wing length $\mathrm{I} \cdot 3-5 \mathrm{~mm}$.

Head yellowish, A.R. 2:5. Thorax yellowish, shoulders white, stripes slightly darker, pleura with a median dark stripe. Legs mainly yellowish, femora more or less darkened at apex, anterior tibia with sub-basal dark ring and dark at apex, other tibiae may be dark as well; scale with short spur; anterior tarsi missing but probably as in female, i.e. L.R. 2, segment I with apical third dark, segments 2-4 with apical half or more dark. Wings (Pl. I, fig. $d$ of female) with main marking as a broad band from apical half of $\mathrm{R}_{1}$ across posterior fork cell and apex of anal cell, leaving a pale spot in fork cell; a second, more poorly developed band reaches from 
cross-vein to middle of anal cell ; apical band extended in cell $\mathrm{M}_{2}$ both apically and basally sometimes more or less joined to basal band as shown in figure of female; apex of wing also with a small dark patch; base of cell $\mathrm{R}_{5}$ clear and forming a conspicuous pale spot. Halteres dark. Abdomen yellowish brown with variable dark markings, each segment broadly pale apically, styles pale; hypopygium (Text-fig. I, $d$ ) with narrow appendage I and anal point, appendage 2 with long apical hair.

Female resembles male but wings more strongly patterned.

The types of leucolabis, filitarsis and tenuitarsis are lost, all were from FRENCH CAmeroons: Kribi. I have seen the holotype female of fenestralis in Musée Royal du Congo Belge, Tervuren (Belgian Congo : Vitshumbi).

Distribution. Nigeria: i $q$, Zaria, xi.I956 (B. McMillan). Sudan: i $q$, Muklei, v.I953 (G. S. Rennie) ; series of 우 from Amadi, Yirol, Wau and Tonga, I952-54 (E. T. M. Reid. Belgian Congo: I ô, I +, Maka Lualaba, i. I939 (H. J. Brédo); I ô. Elisabethville, xii. I938 ( $H . J$. Brédo). TransvaAl: I +, Letaba, v.I95I (P. Brinck). The type localities are additional.

\section{Polypedilum (Polypedilum) annulatipes Kieffer}

Polypedilum annulatipes Kieffer, I921, Ann. Soc. sci. Brux. 41 (I) : roo; Kieffer, I922, Ann. Soc. ent. France, $91: 30$.

? Polypedilum octostictum Kieffer, I921, Ann. Soc. sci. Brux. 41 (I) : Ior ; Kieffer, I922, Ann. Soc. ent. France, $91: 39$.

Polypedilum octomaculatum Goetghebuer, 1934, Rev. Zool. Bot. Afr. 25 : I95; Goetghebuer, I936, ibid. $28: 488$ (sYN. Nov.).

A small dark species with wing pattern not unlike temuitarsis but the cross-vein and basal cells are quite clear and there is a discrete spot in the apical half of cell $\mathrm{R}_{5}$; male hypopygium with appendage I clubbed. P. annulatipes is easy to recognize from Kieffer's description and octomaculatum at any rate must fall as a synonym. The description of octostictum is not quite so certain, but the resemblance is strong and it probably is another synonym. The wing pattern resembles allansoni (see below) but the male hypopygium is quite different.

Male. Wing length $\mathrm{I} \cdot 5^{-\mathrm{I}} \cdot 8 \mathrm{~mm}$.

Head and mouthparts dark brown, antennae paler, A.R. about 2. Thorax dark brown or blackish and pruinose, pruinosity of hair lines and stripes changeable ; dorsocentral bristles pale and uniserial. Legs yellowish brown, the femora being the darkest part with tips blackish and with a subapical pale band which is progressively wider from front to back legs ; L.R. 2, anterior tarsus not bearded, scale triangular and with sharp point. Wings (Pl. I, fig. $e$ of female) with a broad band as shown and separate spots in cell $R_{5}$, anal cell and below posterior fork; there may be additional darkening at the apex of fork cell and the area of darkening in cell $\mathrm{M}_{2}$ may be more extended basally but it does not reach basal to cross-vein. Halteres pale. Abdomen black; hypopygium (Text-fig. I, e) with narrow styles, anal point elongate, appendage I club-shaped.

Female very similar to male; some specimens from Gold Coast have wing length only $\mathrm{I} \cdot 0 \mathrm{~mm}$.

ENTOM. 6, II. 
The holotype male of anmulatipes (locality Belgian Congo: Go) and holotype female of octosticum (French CAMERoons: Kribi) are both lost. I have seen the holotype male of octomaculatum in Musée Royal du Congo Belge, Tervuren (locality Belgian Congo: Kisantu).

Distribution. Gold CoAst : I3 우, Kete Krachi, x.I898 (Graf Zech). Nigeria : 2 ㅇ, Abuja, xii.I954 (R. W. Crosskey); I ô, Katsina, x.I956 (B. McMillan). Sudan : 2 o, Amadi, vii.I954 (E. T. M. Reid). Belgian Congo: I ô, Banana (H. Schouteden); I ㅇ, Elisabethville, xii.I938 (H. J. Brédo); holotype of octomaculatum, Kisantu. S. RHodesia: I ô, 5 o , Salisbury, v.I956 (E. T. M. Reid). Transvaal: 3 ô, Pongola R. Settlements, ix.I954 (A. D. Harrison). Natal: I , Weenen, x.I924, (H. P. Thomasset).

\section{Polypedilum (Polypedilum) abyssiniae Kieffer}

Polypedilum abyssiniae Kieffer, 1918, Ann. Mus. nat. Hung. 16: 65.

Polypedilum niveiforceps Kieffer, I921, Ann. Soc. sci. Brux. 41 (I) : Ior ; Kieffer, I922, Ann. Soc. ent. France, 91:4I (syn. Nov.); Freeman, 1955, Explor. Parc Nat. Albert, Miss. de Witte, $83: 26$.

Polypedilum novemguttatum Kieffer, I921, Ann. Soc. sci. Brux. 41 (I) : Ior ; Kieffer, I922, Ann. Soc. ent. France, $91: 42$ (syn. Nov.).

A small dark species with patterned wings ; there is a spot basal to the cross-vein as in longicrus and griseoguttatum but it may be distinguished from these by the clear base to cell $R_{5}$ and by the smaller spot behind the apex of $R_{4+5}$. Male anal point unusual, it is conical and with broad flattened spines each side. I was able to see the type of abyssiniae; the other two belong here judging from the wing pattern and the male genital structure of niveiforceps.

Male. Wing length $\mathrm{I} \cdot 5 \mathrm{~mm}$.

Head blackish, mouthparts brown, A.R. about I·4. Thorax very dark brown, prescutellar area quite strongly pruinose, lines of bristles also pruinose. Legs yellowish brown, apices of femora darkened; tibial scale oval and with a short spur, L.R. 2. Wings (Pl. I, fig. $f$ of female) with markings very similar to the female but not always as intense, spot at apex of fork cell sometimes almost absent; important features are the two markings in cell $R_{5}$ and the spot basal to cross-vein. Halteres pale. Abdomen black, styles pale; hypopygium (Text-fig. I, $f$ ) usually with broad conical anal point fringed with 4-5 flattened spines each side, but it may be more square than conical in some specimens ; appendage I with broad apex which is flattened, turned up and produced inwardly, appendage 2 also broad and with about I2 curved hairs at the apex; some specimens from L. Tanganyika have the hairs on appendage 2 greatly reduced, only $3-4$ being present.

Female resembles male, wing pattern usually more intense (Pl. I, fig. $f$ ).

I have seen a cotype female of abyssiniae which was in the Hungarian National Museum (locality Abyssinia: Lake Dembel); the type series of niveiforceps (SUdAN : Shambe) and of novemguttatum (SudAN: Mongola) are lost.

Distribution. Ethiopia: cotype female, Lake Dembel. Sudan: series taken at light on river steamer, Adok, Melut, Shambe, xi.I953 (E. T. M. Reid). Belgian Congo: 23 ô, 22 o, Parc National Albert (H. Damas); 5 ô, Kabimba 
(L. Tanganyika), viii.I953 (J. Verbeke). Tanganyika: 5 ऽૈ, 2 ㅇ, Kigoma, L. Tanganyika, viii. 956 (P. S. Corbet). TransvaAl: I $\hat{0}$, Hartebeestpoort Dam, iv. I957 (B. R. Allanson); I స̂, Kruger National Park, v.I957 (A. D. Harrison).

\section{Polypedilum (Polypedilum) quinqueguttatum Kieffer}

Polypedilum quinqueguttatum Kieffer, I92I, Ann. Soc. sci. Brux. 41 (I) : Ioo; Kieffer, I922, Ann. Soc. ent. France, $91: 32$.

Polypedilum septemguttatum Kieffer, I92I, Ann. Soc. sci. Brux. 41 (I) : Ioo; Kieffer, I922, Ann. Soc. ent. France, $91: 32$ (sYN. Nov.).

Polypedilum sexguttatum Kieffer, I921, Ann. Soc. sci. Brux. 41 (I) : 100; Kieffer, I922, Ann. Soc. ent. France, $91: 35$ (syn. Nov.).

Kribiophilus pictipennis Kieffer, I922, ibid. $91: 43$ (syn. Nov.).

Polypedilum niloticum Kieffer, 1925, Bull. Soc. R. ent. Égypte, 1924:27I (syn. nov.).

This and the next two species are small brown species very similar in general appearance and wing pattern but readily distinguished by the male hypopygium; in the present species the anal point is extremely narrow and set on a conical IXth tergite, also appendage 2 has about I2 curved hairs. Wings of all three species with well-formed spots at base of $\mathrm{M}_{1+2}$, in centre of cell $\mathrm{R}_{5}$, over $\mathrm{Cu}$ and in centre of anal cell; in quinqueguttatum there are also spots at the apices of both branches of $\mathrm{M}$ and no spot basal to the cross-vein. I have not seen the types of any of Kieffer's species but the descriptions, with characteristic wing pattern leave no doubt about their identity.

Male. Wing length $\mathrm{I} \cdot 3-\mathrm{I} \cdot 5 \mathrm{~mm}$.

Head and mouthparts brown, A.R. about I.I. Thorax brown or dark brown, with some pruinosity especially in the prescutellar area. Legs yellowish, femora darker basally; tibial scale oval and with very small spur, L.R. I.8. Wings (Pl. I, fig. $g$ of female) with six spots which are smaller than in longicrus and there is not one basal to cross-vein, sometimes spots rather faint. Halteres with brown or dark knobs. Abdomen black, styles pale. Hypopygium (Text-fig. 2, a) with characteristic narrow anal point set on conical IXth tergite; appendage I foot-shaped, appendage 2 with about $\mathrm{I} 2$ hairs.

Female resembles male.

The types of all species are lost, the first four were all described from FRENCH CAMEROONS: Kribi, with only sexguttatum being known in the male; niloticum was described from a male from EGYPT : Maadi.

Distribution. Nigeria: 2 ㅇ, Abuja, xii.r954 (R. W. Crosskey). Sudan : 3 ㅇ, Khartoum, x.I95I (D. J. Lewis) ; 6 ô, 2 오, Amadi, vi-vii.I954 (E. T. M. Reid). Natal: I ô, Tugela R., Ngobevu, iii. I954 and I ô, I +क, Jameson's Drift, iv. I954 $(W . D$. Oliff). With the type localities this species has a very wide distribution.

\section{Polypedilum (Polypedilum) longicrus Kieffer}

Polypedilum longicrus Kieffer, I92I, Ann.Soc. sci. Brux 41 (I) : Ior ; Kieffer, I922, Ann. Soc.ent. France, $91: 40$.

Polypedilum duodecimpustulatum Goetghebuer, 1936, Rev. Zool. Bot. Afr. $28: 484$ (syn. Nov.) ; Freeman, 1955, Explor. Parc Nat. Albert, Miss. de Witte, 93: 27 (not Freeman, 1955, S. Afr. Animal Life. Uppsala, 2: 377-see P. tropicum). 
A small species with patterned wings, differing from quinqueguttatum and tropicum only in the wing pattern and male hypopygium. Wings (Pl. I, fig. $h$ ) have some apical grey clouding around the margin, a spot basal to the cross-vein and a grey tract between $\mathrm{M}_{1+2}$ and $\mathrm{M}_{3+4}$, in addition to the four main spots which are present in all three species. Anal point of male (Text-fig. 2, $b$ ) short and stout and strongly bent downwards, IXth tergite broad, the whole appearance being more like tropicum than quinqueguttatum; appendage 2 carries about six curved hairs and appendage I is curved.

The identity of longicrus is quite certain from the original description although the type is lost (type locality Belgian Congo: Go) ; I have seen the holotype of I2-pustulatum in Musée Royal du Congo Belge, Tervuren and can confirm the synonymy (type locality BELGIAN CoNGo: Vitshumbi).

Distribution. Gold Coast: I ô, 2 ㅇ, Nangodi, x.I954 (G. Crisp). Sudan : numerous specimens, Rier, Khartoum, Wad Medani, Shambe, Wau (D. J. Lewis, S. Hirst, E. T. M. Reid). Uganda: Ið̊, Nimule, viii. Igir. Belgian Congo: 2 ô, Kamande (H. Damas) ; 3 ô, Elisabethville, iii.I939 (H. J. Brédo). The type localities are additional.

\section{Polypedilum (Polypedilum) tropicum Kieffer}

Polypedilum tropicum Kieffer, 1913, Voy. All. Jean. Afr. Or. Ins. Dipt. 1 : 2 I.

Polypedilum trilobatum Kieffer, I921, Ann. Soc. sci. Brux. 41 (I) : 100; Kieffer, 1922, Ann. Soc. ent. France, $91: 34$; Freeman, 1955, Explor. Parc Nat. Albert, Miss. de Witte, 83: 27 (syN. Nov.).

Polypedilum ? duodecimpustulatum Freeman, 1955, S. Afr. Animal Life. Uppsala, $2: 377$ (not Goetghebuer, 1936, Rev. Zool. Bot. Afr. $28: 484$ ).

This species, again, can only be distinguished from quinqueguttatum and longicrus by the wing markings (Pl. I, fig. $i$ ) and the male hypopygium (Text-fig. 2, $c$ ). Wings with four large spots and a slight grey tract between the branches of $\mathrm{M}$; no spot basal to cross-vein. Hypopygium with a three-lobed anal point, appendage 2 narrow and with only three, well spaced, hairs; appendage I slightly curved outwards.

I have seen the holotype female of tropicum in Muséum National d'Histoire Naturelle, Paris (type locality Kenya: Taveta); the male hypopygial structure agrees exactly with the figure given by Kieffer in his description of P. trilobatum, the type series of which is lost (type locality Sudan: Mongola).

Distribution. Nigeria: 4 을 Abuja, xii.I954 (R. W. Crosskey). Sudan : 2 ㅇ, Amadi and I ․ Juba, vi-vii.I954 (E. T. M. Reid). Belgian Congo: I ô, May-ya-Moto (de Witte). TransvaAl : I ô, Pongola Settlements, ix. I954 (A. D. Harrison) ; I +, Skukuza, v.I955 (A. D. Harrison). Basutoland : I , Makhake Mts. (P. Brinck). CAPE Province : 5 o, Tzitzikama Forest (P. Brinck).

\section{Polypedilum (Polypedilum) pruina Freeman}

Polypedilum pruina Freeman, 1954, Proc. R. ent. Soc. Lond. (B) 23 : 179; Freeman, I955, S. Afr. Animal Life. Uppsala, 2:376.

Very similar to the preceding three species but easily distinguished by the presence 
of three distinct spots in cell $\mathrm{R}_{\mathbf{4 + 5}}$ and by the male hypopygium which is more like that of aegyptium.

Male. Wing length $\mathrm{I} \cdot 3-\mathrm{I} \cdot 5 \mathrm{~mm}$.

Head, mouthparts and antennae brown, A.R. hardly more than I. Thorax dark brown and pruinose especially in prescutellar area, pruinosity changes on to stripes when direction of light changes. Legs yellowish, basal two-thirds of femora darker, anterior legs whitish and with tarsal segments 2-5 darker basally, L.R. about I.75, scale oval and with short spine at apex. Wings (Pl. I, fig. $j$ of female) with three spots in cell $R_{5}$, other spots very similar to those of quinqueguttatum, no spot basal to cross-vein; halteres with brown knobs. Abdomen blackish; hypopygium (Text-fig. 2, $d$ ) with anal point broad and downturned and with lateral teeth basally of variable length giving a trilobed appearance; appendage I with two long strong inwardly pointing spines and a curved apical one; appendage 2 with about 6-7 apical hairs.

Female resembles male.

Holotype male in the British Museum (type locality CAPE Province : Piquetberg).

Distribution. Cape Province: type locality; $7 \hat{\jmath}$, Upington, xi.I95o ( $P$. Brinck). Natal: I o, Weenen, x.I924 (H. P. Thomasset); I ô, Mooi River, Keate's Drift, iv.r954 (W. D. Oliff). Sudan: I ô, Amadi, vi-vii.I954 (E. T. M. Reid). Nigeria : I ô, Kankiya, xii.I956-i.I957 (B. McMillan).

\section{Polypedilum (Polypedilum) aegyptium Kieffer}

Polypedilum aegyptium Kieffer, I925, Bull. Soc. R. ent. Égypte, 1924 : 270 (Polypedilum iris on the figure-laps. cal.).

Polypedilum iris Goetghebuer, 1937, in Lindner, Flieg. Pal. Reg. 3 (13c) : 61 (in part).

Polypedilum aïrense Freeman, I956, Bull. I. F. A. N. 18 (A) : 96 (syn. nov.).

A small dark species, easily separated from all except the next by the faint wing markings ; separated from subovatum sp. $\mathrm{n}$. by the quite different male hypopygium.

Although the type series is lost, the species can be recognized from the description and figure of the male hypopygium which Kieffer unfortunately labelled as belonging to his previous species (iris). This is clearly an error because iris is described from the female only. Goetghebuer (I937) followed this error and redescribed iris with aegyptium hypopygium. I described aïrense before I had appreciated the identity of aegyptium, and it must fall as a synonym.

Male. Wing length $\mathrm{I} \cdot 4-\mathrm{I} \cdot 6 \mathrm{~mm}$.

Head, mouthparts and antennae brown, A.R. about I.2. Thorax dark brown and pruinose, shoulders slightly paler. Legs yellowish brown, tibial scale conical and with short spur, L.R. I·75. Wings (Pl. I, fig. $k$ of female) with a faint cloud at the base of cell $R_{5}$, more or less connected to a similar cloud in base of fork cell and apex of anal cell and with another cloud placed centrally in the anal cell; long veins sometimes faintly seamed with grey, cell $\mathrm{R}_{5}$ occasionally with a faint cloud at the apex. Halteres pale or with brownish knobs. Abdomen black; hypopygium (Text-fig. $2, e$ ) very similar to pruina but appendage I more angular and only one inner spine present, appendage 2 with more hairs. 
Female resembles male, tibiae may have dark apices.

Type series lost (locality EGYPT: Maadi). Holotype male of aïrense in Institut francais d'Afrique noire, Dakar (locality French West Africa : Niger, Aïr).

Distribution. Egypt: I $\hat{\sigma}$, Moascar, ii.I942 (J.W. S. Macfie). Sudan :

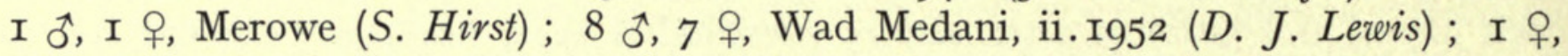
Rier, ii.I946 (D. J. Lewis). French West Africa: Niger, Aïr, type series of aïrense.

\section{Polypedilum (Polypedilum) subovatum sp. n.}

In colour, general structure and wing pattern, exactly similar to aegyptium but easily separated by the male genital structure. Anal point lacking lateral teeth (Text-fig. $2, f$ ), appendage I much broader and ovate with 6 long hairs, appendage 2 with about $\mathrm{I} 8$ curved hairs.

Female not known.

Holotype male, Cape Province: Berg River, Driefontein, I7.xii.54 (K. M. F. Scott) in the British Museum.

\section{Polypedilum (Polypedilum) tridens Freeman}

Polypedilum tridens Freeman, 1955, Explor. Parc Nat. Albert. Miss. de Witte, 83 : 28.

A wide-spread, small, dark species with plain wings and dark halteres; anal point of male trifid and whole hypopygium very similar to others with this character especially allansoni, but easily separated from them by the plain wings; the female is difficult to distinguish from other dark, plain-winged species although the dark halteres are sometimes helpful.

Male. Wing length $\mathrm{I} \cdot 5 \mathrm{~mm}$.

Head, mouthparts and antennae dark brown, A.R. about I.5. Thorax dark brown, paler on the shoulders, pruinose on shoulders and between stripes. Legs yellowish, tibial scale triangular and with a well-formed black spine at apex, L.R. 2 . Wings unmarked or veins very slightly seamed with grey; halteres with dark knobs. Abdomen blackish; hypopygium (Text-fig. 2, g) with anal point short, broad and arched and with a short lateral pointed lobe on each side ; appendage I short broad and pubescent with a larger spine projecting inwardly; appendage 2 with 8-9 curved hairs in two rows.

Female resembles male.

Holotype male in collection of Institut des Parcs nationaux du Congo Belge (type locality BELGIAN Congo: Rutshuru).

Distribution. Egypt : 6 ô, 3 우, Moascar, ii-iii.I942 (J.W.S. Macfie). SudAn : 7 ㅊ, 2 ㅇ, Shambe, Adok and Rumbek (E. T. M. Reid). Abyssinia: I to, 2 우, Waldia, i-ii. 1939 (J.W. S. Macfie). Nigeria : 5 ô, Zaria, xi.r956 (B. McMillan). French West Africa: I5 ô, 4 , Haute Volta, nr. Banfora, xii.I956 (J. Hamon). Uganda: I $\hat{\jmath}$, Jinja, i.I956 (P. S. Corbet). Belgian Congo: type series from

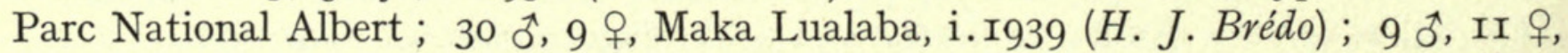
Elisabethville, xii.I938-iv.I939 (H. J. Brédo); I ô, Eala, i.I935 (J. Ghesquière). 
Transvaal: I ô, Blyde River, ix.I954 (A. D. Harrison). Natal: 5 ô, 3 q, Estcourt, ix.I953 (A. D. Harrison); I ô, Scottburgh, vii.I953 (K. M. F. Scott).

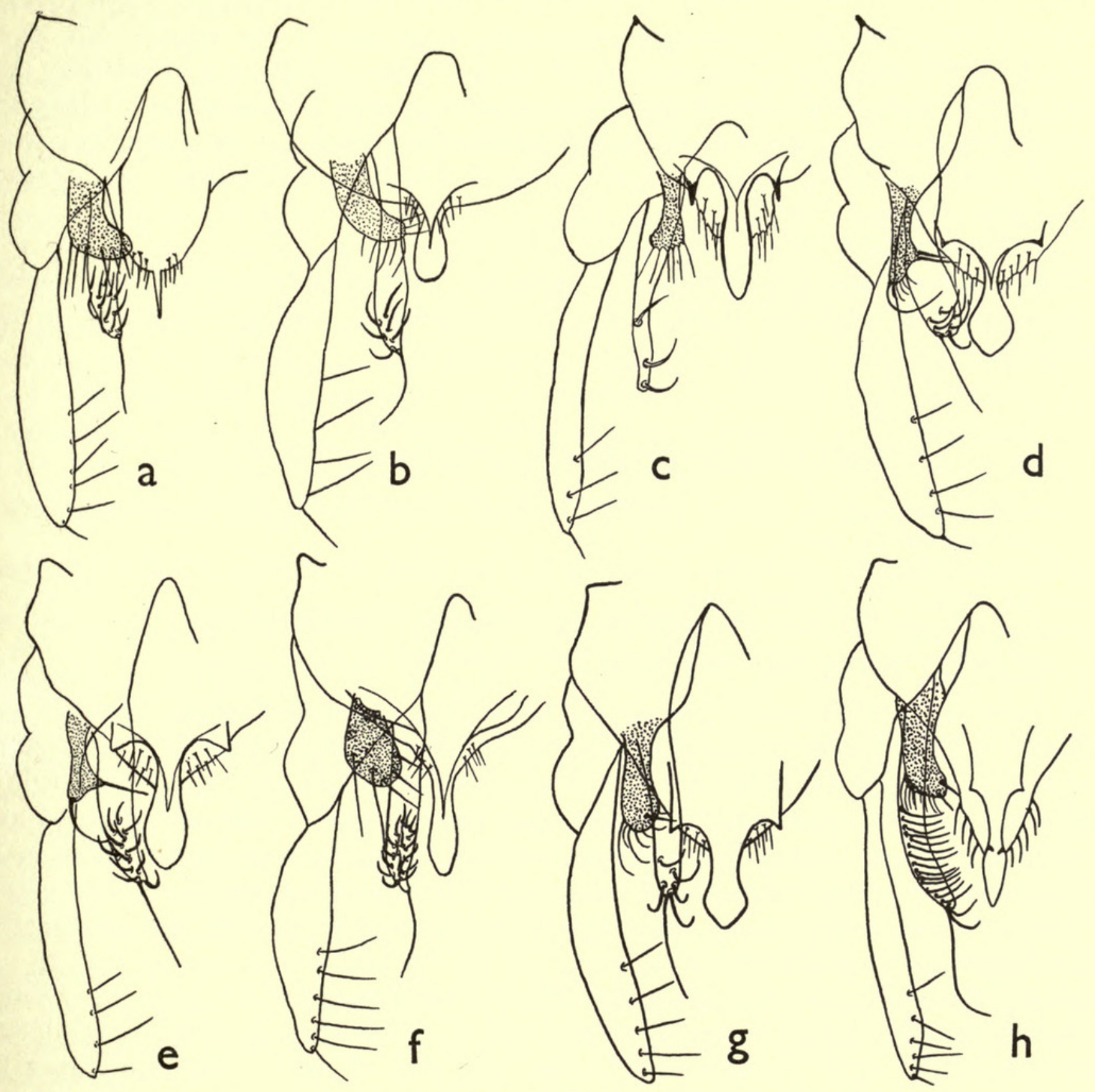

FIg. 2. Male hypopygia of Polypedilum (Polypedilum). (a) P. quinqueguttatum; (b) P. longicrus; (c) P. tropicum; (d) P. pruina; (e) P. aegyptium; (f) P. subovatum; (g) P.tridens; (h) P. griseoguttatum.

\section{Polypedilum (Polypedilum) allansoni sp. n.}

A small dark species with pruinose thorax, femora with subapical clear band, wings with dark spots ; the wing pattern is very similar to annulatipes but the grey tract in cell $\mathrm{M}_{2}$ is separated into two spots ; it is best separated from anmulatipes by the structure of the male hypopygium in which the anal point is trifid and is very similar to tridens.

Male. Wing length $\mathrm{I} \cdot 5 \mathrm{~mm}$. 
Head, mouthparts and pedicel dark brown, flagellum paler, A.R. about I. Thorax dark brown and pruinose, especially in the prescutellar area. Legs mainly pale brown, but femora darker and with a subapical pale band, L.R. I'75. Wings with pattern very similar to that of annulatipes ( $\mathrm{Pl}$. I, fig. e) but the tract in cell $\mathrm{M}_{2}$ is present as two separate spots, one slightly basal to the larger spot in cell $R_{5}$, the other slightly basal to the smaller spot in that cell ; apex of fork cell clear. Abdomen dark brown, styles yellowish. Male hypopygium hardly to be distinguished from that of tridens (Text-fig. 2, g), anal point almost identical, appendage I with rather fewer hairs.

Female not known.

Holotype male and 4 ô paratypes, TransvaAl : Blaauwbank River, near Sterkfontein caves, iv. I957 and I ô,iii.I957 (B. R. Allanson). All specimens are in the British Museum.

\section{Polypedilum (Polypedilum) griseoguttatum Kieffer}

Polypedilum griseoguttatum Kieffer, I921, Ann. Soc. sci. Brux. 41 (I) : Ioo ; Kieffer, I922, Ann. Soc. ent. France, $91: 36$.

Polypedilum hievoglyphicum Kieffer, I921, Ann. Soc. sci. Brux. 41 (I) : Ior ; Kieffer, I922, Ann. Soc. ent. France, $91: 38$ (syn. Nov.).

Polypedilum decem-maculatum Goetghebuer, I934, Rev. Zool. Bot. Afr. 25 : I95 (syn. Nov.). Polypedilum van-bemmeli Kruseman, 1949, Bijdr. Dierk. 28: 254 (syn. Nov.).

A small- to medium-sized dark species with strongly marked wings; thorax and abdomen with pruinosity, wing markings of variable intensity but include three dark markings of variable shape in cell $\mathrm{R}_{5}$ and a spot basal to cross-vein ; male hypopygium with IXth tergite drawn out, anal point more or less trifid. The only type I have been able to see is that of decem-maculatum, but the wing markings and the male hypopygium are so distinctive that I have no hesitation in giving the above synonymy.

Male. Wing length $\mathrm{I} \cdot 5-2 \cdot 5 \mathrm{~mm}$., specimens from Sudan and Egypt are smaller than those from further south.

Head dark brown, mouthparts and antennae paler brown, A.R. about 2. Thorax dark brown, lines of bristles paler, whole mesonotum pruinose, pruinosity of stripes and prescutellar area changeable with the direction of light; scutellum may be yellowish. Legs with all femora brown on basal three-quarters or more, apex yellow ; front and posterior tibiae yellow, middle tibiae brown; tarsi yellow, anterior basitarsus completely yellow, all other segments with basal quarter or more brown; L.R. varying from $\mathrm{I} \cdot 5-2 \cdot 0$, scale of anterior tibiae triangular and with a well-developed sharp spur. Wings (Pl. I, figs. l-o of females) strongly marked with a complicated pattern ; there is a spot basal to cross-vein and cell $R_{5}$ always has three markings but these vary in shape in different localities, the two apical ones are usually more diffuse but they may be discrete. Abdomen blackish, hypopygium partially yellow, each segment either pruinose on apical half or with pruinose band divided into two separate spots ; hypopygium (Text-fig. $2, h$ ) with characteristic conical IXth tergite; anal point with lateral teeth of variable size, apex curved downwards and arched, sometimes with side notches as shown; appendage I stout and with two 
small inner spines, appendage 2 may have the curved hairs in a single row or they may be grouped nearer the apex; styles elongate.

Female similar to male.

The type series of griseoguttatum (French CAMERoons: Kribi) and of hieroglyphicum (SUDAN: Shambe) are lost; I have seen the holotype male of decemmaculatum in Musée Royal du Congo Belge, Tervuren (Belgian Congo: Kisantu) ; the holotype male of van-bemmeli is in the Zoological Museum, Amsterdam (EGYPT : Suez Canal).

Distribution. Egypt : $3 \hat{\sigma}$, I 9 , Suez Canal, x. I934 (F. W. Edwards). Sudan :

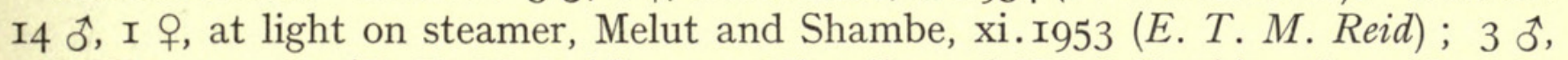
I + , Wau, x.I952 (E.T.M. Reid) ; 2 ô, Rier, ii.I946 (D.J. Lewis). Gold Coast : I , Nangodi, x.I954 (G. Crisp). French Cameroons: i + , Douala (J. Rageau).

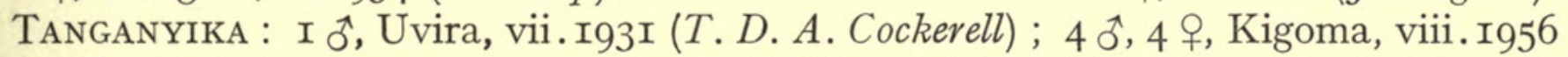
(P. S. Corbet). Belgian Congo: I $\hat{\jmath}$, Kasenyi (L. Albert) and Kabimba (L. Tanganyika), viii.I953 (J. Verbeke); 6 sิ. Sabe, xii.I953; 4 ㅇ, Elisabethville, xii. I938 (H.J. Brédo). N. Rhodesia : I ô, Luangwa River, viii. I930 (S. A. Neave). MADAGASCAR: I + , Tananarive, v.I956 (J. Hamon).

\section{Polypedilum (Polypedilum) ramiferum Kieffer}

Polypedilum ramiferum Kieffer, I921, Ann. Soc. sci. Brux. 41 (I) : 98 ; Kieffer, 1922, Ann. Soc. ent. France, $91: 24$.

Polypedilum brevipecten Kieffer, I92 I, Ann. Soc. sci. Brux. 41 (I) : 99 ; Kieffer, I922, Ann. Soc. ent. France, $91: 27$ (SYN. Nov.).

Wings either faintly clouded or with well-formed clouds; legs marked with black and yellow, abdomen with tergite 5 and sometimes 4 and 6 pale, styles of male hypopygium with long plumose hairs. Very similar to the next species from which it can be separated by the male hypopygium and the less intense leg and wing markings. The descriptions given by Kieffer and his figures of the male leave no doubt that both of his species are the same and are correctly identified as this one, even though he considered the wings to be plain; the wing markings are often difficult to see in spirit material.

Male. Wing length $2-3 \mathrm{~mm}$.

Head, mouthparts and antennae brown, A.R. about I. Thorax brown and rather shining though with some pruinosity in certain lights; dorso-central bristles bior triserial, long and brown. Legs dark brown or blackish, femora with a darker subapical ring; base and apex of tibiae and of tarsal segments yellow ; middle and posterior tibiae usually with an additional broad yellow central band which may eliminate the sub-basal dark area so that the basal half or more of the tibia is yellow ; L.R. about I.75; tibial scale triangular and with a curved spur at the apex. Wings (Pl. I, fig. $p$ of female) with pattern either faint or well developed, not unlike albosignatum; halteres yellow or brown. Abdomen brown, each segment with pale posterior band; at least segment 5 and often either 4 or 6 as well, pale and with pale hair. Hypopygium (Text-fig. 3,a) quite unlike any other African species known 
to me because the hairs along the inner margin of the style are very long and plumose ; anal point long and narrow, appendage I broad basally, sharply contracted and bent at the middle, apical half narrow and straight, appendage 2 long.

Female resembles male, wing markings usually more definite.

Types of both species lost (both were described from males from FrencH Cameroons: Kribi).

Distribution. Sudan : 5 ô, Khartoum, xi.I95I (D. J. Lewis) ; i 우, Amadi, vi-vii.I954 (E. T. M. Reid). Nigeria : I 오․ Minna, xii.I954 (R. W. Crosskey). Uganda: I2 0 , 3 + Jinja, x. I954 (P. S. Corbet). Belgian Congo: I ô, Kusenyi (L. Albert), ii.I953 (J. Verbeke); 20 ơ, Albertville, viii.I953 (J. Verbeke). The type locality is additional.

\section{Polypedilum (Polypedilum) albosignatum Kieffer}

Polypedilum albosignatum Kieffer, 1925, Bull. Soc. R. ent. Égypte, $1924: 268$.

Polypedilum iris Kieffer, 1925, ibid. 1924 : 269 ; Goetghebuer, 1937, in Lindner, Flieg. Pal. Reg. 3 (I3c) : 6I (in part) (sYN. Nov.).

Wing markings and general appearance similar to ramiferum, differing in detail and intensity, segment 5 of abdomen brown, male hypopygium quite different, anal point short and thick, appendage I reduced. Kieffer separated his two species because albosignatum had only one spot in the anal cell whereas iris had two; but he stated that the wing base of the former was subhyaline which suggests that the spot was really there. However, whether such a spot is there or not is immaterial in species with these nebulous markings and I am regarding his two species as synonyms. As mentioned under aegyptium, Kieffer labelled the figure of aegyptium as "iris" in error and Goetghebuer followed this mistake.

Male. Wing length $\mathrm{I} \cdot 5-2 \cdot 0 \mathrm{~mm}$.

Head, mouthparts and antennae brown, A.R. about I·4. Thorax brown, scarcely shining and with slight pruinosity, dorso-central bristles more or less uniserial, long and brown. Legs yellowish brown, femora darker on basal half and dark at apex, tibiae vaguely darkened basally and apically, tarsi without dark markings ; L.R. 2 ; tibial scale triangular and with short spur. Wings (Pl. I, fig. $q$ of female) with pattern not unlike ramiferum, not very intense, pale areas more confined; halteres brown. Abdomen brown, each segment with a pale apical ring, segment 5 dark; hypopygium (Text-fig. $3, b$ ) with short stout anal point, appendage I short and with 3 long hairs at the apex, appendage 2 narrow and with only $4-6$ hairs at the apex, style hairs not plumose.

Female similar to male, wing markings more intense.

Type series of both species lost, both were described from females from EGYPT : Maadi.

Distribution. Sudan: 2 ô, 3 우, Khartoum, i.I923 (S. Hirst); 8 ô, 3 ㅇ, Khartoum, x. I95I (D. J. Lewis); I ô, 3 ㅇ, Liednum nr. Wau, iii-iv. I955 (E. T. M. Reid). Uganda : 25 ô, Kagera R., iv. I955 (P. S. Corbet). The type locality gives it a distribution overlapping into the Palaearctic Region. 


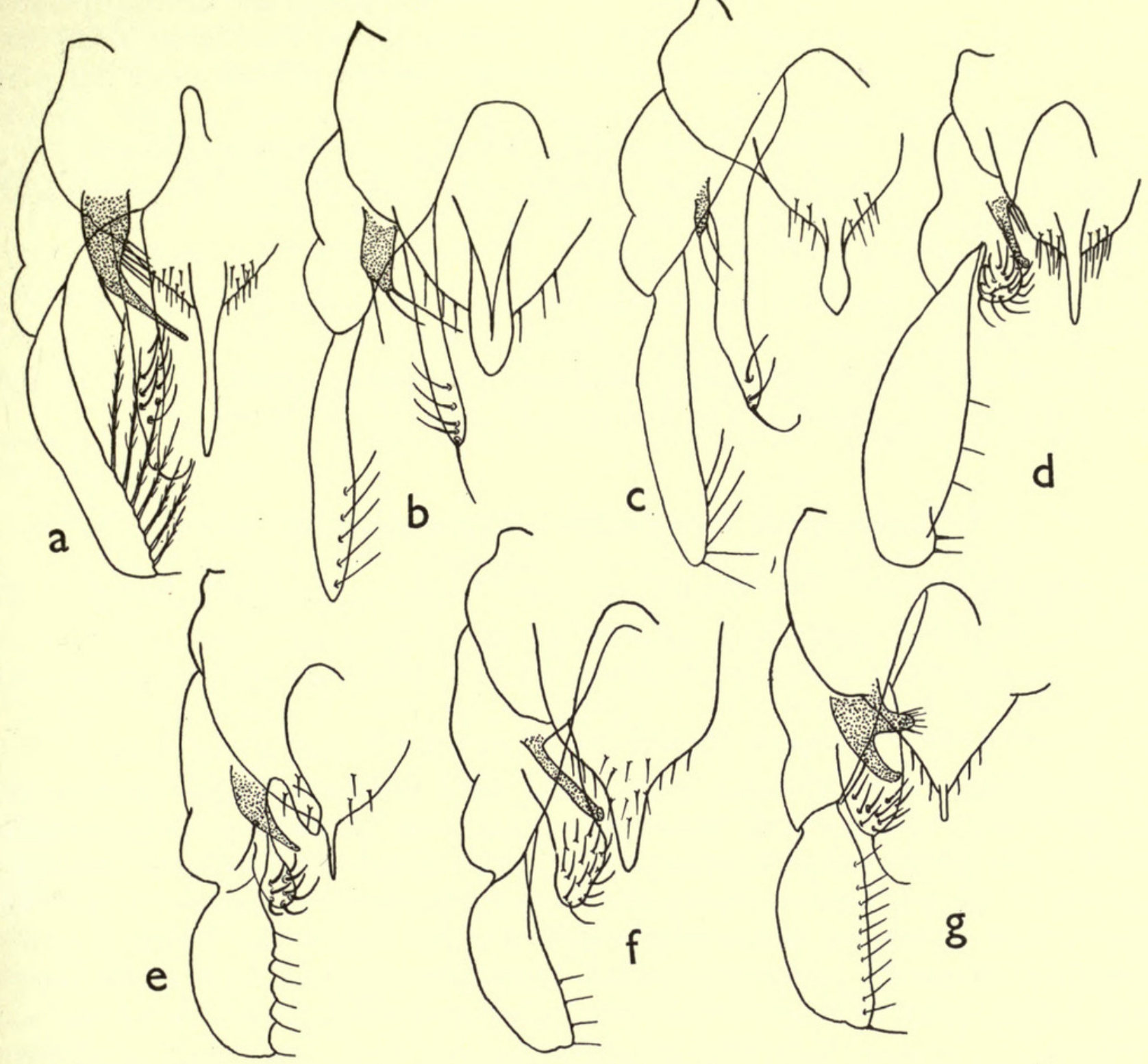

FIg. 3. Male hypopygia of Polypedilum (Polypedilum). (a) P. ramiferum;

(b) P. albosignatum; (c) P. alboguttatum; (d) P. fuscipenne; (e) P. declivis;

(f) P. lobiferum; (g) P. longinervis.

\section{Polypedilum (Polypedilum) alboguttatum Kieffer}

Polypedilum alboguttatum Kieffer, I92I, Ann. Soc. sci. Brux. 41 (I) : 99; Kieffer, I922, Ann. Soc. ent. France, $91: 29$.

Wings black or very dark brown with IO-II small clear spots, legs mainly black, tarsi marked with yellow. Hypopygium of similar type to albosignatum, but the wing markings are much more intense and make the species readily recognizable.

Male. Wing length $\mathrm{r} \cdot 5 \mathrm{~mm}$.

Head, mouthparts and antennae brown, A.R. I.5. Thorax mottled pale brown, strongly pruinose on shoulders and prescutellar area, dorso-central bristles uniserial, postnotum blackish. Legs with femora and tibiae black, femora with a broad pale band in basal half, knees with a spot of yellow, tarsi much paler, segments 
marked with brown on basal halves; L.R. $2 \cdot 2$, scale triangular, sharply pointed. Wings (Pl. I, fig. $r$ of female) blackish or very dark brown with Io-II small clear spots; main pattern not unlike albosignatum but details and intensity different; halteres with black knobs. Abdomen black, each segment with a pale pruinose band apically, styles whitish ; hypopygium (Text-fig. 3,c) of same general form as albosignatum but appendage $\mathrm{I}$ more reduced, appendage 2 with fewer apical hairs, anal point broad and strongly bent downwards.

Female similar to male, cerci yellow.

Type series lost, described from 6 females from Sudan : Shambe.

Distribution. Sudan: 2 б, I7 ㅇ, Melut, xi.r953 (E. T. M. Reid); I ô, 2 ㅇ, Liednum nr. Wau, iii-iv.I955 (E. T. M. Reid). UGANDA : 2 우 L. Albert, iii.r954 (P. S. Corbet) ; 2 o, Albert Nile at Pakwach, iv.I956 (P. S. Corbet).

\section{Polypedilum (Polypedilum) fuscipenne Kieffer}

Polypedilum fuscipenne Kieffer, I921, Ann. Soc. sci. Brux. 41 (I) : 98 ; Kieffer, I922, Ann. Soc. ent. France, $91: 22$.

Tripedilum armatifrons Kieffer, I92I, Ann. Soc. ent. France, $90: 47$ (SYN. Nov.)

Polypedilum longiforceps Kieffer, I921, Ann. Soc. sci. Brux. 41 (I) : 98 ; Kieffer, I922, Ann. Soc. ent. France, $91: 23$ (sYn. Nov.).

Microtendipes longiventris Kieffer, I922, ibid. 91 : I5 (syn. Nov.).

Reddish with black antennal plumes and dark abdomen, thorax shining and sometimes with variable dark markings, especially in the female; frons produced into two lobes each bearing a small frontal tubercle ; wings without distinct markings; male styles large and long, anal point short, coxites produced ventrally. The frontal tubercles and general colour characters make it quite certain that I have identified armatifrons correctly; fuscipenne seems to have been described from a dark female, whilst longiforceps and longiventris can be recognized from the figures of the male hypopygia. The name fuscipenne was published two days earlier than armatifrons.

Male. Wing length $2 \cdot 3-3 \cdot 0 \mathrm{~mm}$.

Head reddish yellow, mouthparts darker, antennae with blackish plumes and reddish pedicel, A.R. about 2.75 ; frons with two conical lobes carrying the small frontal tubercles at their extremities. Thorax shining reddish yellow, sometimes with indications of a dark lateral pleural stripe, stripes rather more reddish than remainder of thorax, postnotum more or less dark. Legs yellow, apices of anterior femora and tibiae and of tarsal segments darkened, tarsus not bearded, L.R. $2 \cdot 3$; scale triangular and carrying a strong black spine as long as the scale itself. Wings without distinct markings but slightly darker or yellowish along costal margin; halteres blackish or brown. Abdomen blackish and shining, each segment may have a variable amount of browner colouring in basal half; hypopygium (Text-fig. 3, d) with long stout styles and short anal point, appendages both small, 2 without long apical hair, inner margins of coxites produced ventrally and fringed to resemble a third appendage (not shown in the figure).

Female resembles male, but darker; head may be brown, thoracic stripes partially or completely black, wings more strongly tinted and abdomen often quite black. 
Type series of all four species lost; armatifrons was described from females and longiventris from males from FrenCH CAMEROONS: Kribi ; fuscipennis from a female from SudAN: Shambe and longiforceps from males from SudAN: Mongola and Shambe.

Distribution. Sudan: I2 ô, 7 ㅇ, Yirol, iii-vii.I954 (E. T. M. Reid); 3 ô, Waụ, iii-iv.r955 (E. T. M. Reid). Gold Coast : 3 ô, 7 우, Nangodi, x. 9954 (G. Crisp). Nyasaland: 3 ふै, Karonga, SW. shores L. Nyasa, vii. I9io (S. A. Neave). Belgian Congo: 7 우, Maka Lualaba, i.I939 (H. J. Brédo); 8 옹 Elisabethville, ii. $\operatorname{I939}$ (H. J. Brédo).

\section{Polypedilum (Polypedilum) declivis Kieffer}

Kribionympha declivis Kieffer, I922, Ann. Soc. ent. France, 91 : 7 ; Freeman, 1957, Mém. Inst. Sci. nat. belg. 8 : 198.

Thorax yellowish and with a central dark stripe; head and abdomen blackish, legs yellow, scale triangular, wings unmarked, male hypopygium with short styles and three well-formed appendages. The presence of frontal tubercles separates this species from all except fuscipenne and lobiferum; from these it may be separated as shown in the key and by the male hypopygium.

Male. Wing length $2 \cdot 3 \mathrm{~mm}$. (one specimen).

Head, mouthparts and antennae brown, frontal tubercles present but do not appear to be raised on conical lobes, A.R. about 2.2. Thorax pale yellowish, the single specimen available to me has a central brown line along the line of the acrostichal bristles, broadening posteriorly and also postnotum and sternopleuron brown. Legs yellow, scale yellow and triangular, its spur short and dark, L.R. $2 \cdot 6$, tarsi not bearded. Wings unmarked and pale, halteres brownish. Abdomen black; hypopygium (Text-fig. 3,e) with oval styles, narrow anal point and three appendages, the lower pair corresponding to the coxite extensions of fuscipenne but better formed.

Female not known.

Holotype male lost, type locality French Cameroons : Kribi.

Distribution. The only specimen known to me is from Belgian Congo: I ô, Albertville, viii.I953 (J. Verbeke).

\section{Polypedilum (Polypedilum) lobiferum Freeman}

Polypedilum lobiferum Freeman, 1954, Proc. R. ent. Soc. Lond. (B) $23: 22$.

Chironomus sp. de Meillon, I937, S. Afr. med. Journ. 1937 : 658-66o.

Blackish with some grey dusting, frontal tubercles present, palpi short, A.R. about 3 , wings plain, male front tarsi with long beard, L.R. I.I, anal point stout and hairy. Shows some structural resemblance to fuscipenne but easily separated by the more general dark colour, the lower L.R. and in the male by the bearded front tarsi and stout anal point.

Male. Wing length $3.5 \mathrm{~mm}$. 
Head, mouthparts and antennae dark, pedicel black, A.R. about 3, well developed frontal tubercles present, more or less raised on conical lobes, palpi short. Thorax completely black and dull, covered with grey pruinosity; acrostichal bristles small and poorly developed, dorso-centrals longer and irregularly biserial, all bristles pale. Legs brown, knees slightly darker, L.R. I.I, scale white and with a short black spur, anterior tarsus with long beard. Wings milky, without dark markings, halteres brown. Abdomen blackish brown, more shining than thorax; hypopygium (Text-fig. 3, $f$ ) with stout hairy anal point, appendage I narrow, down-curved at apex, appendage 2 without long apical hair, styles blunt.

Female similar to male.

Holotype male in the British Museum, type locality CAPE Province: Bergvliet.

Distribution. Known only from CAPE Province : type series from Bergvliet and Mossel Bay; 3 ㅅ․ 3 오, Port Elizabeth, viii.I934 and further series vi.I957 (B. de Meillon). De Meillon (I937) reported that this species bred in enormous numbers in an artificial lake at Port Elizabeth and caused considerable nuisance in the town. He achieved control by raising the salinity.

\section{Polypedilum (Polypedilum) longinervis Kieffer}

Microtendipes longinervis Kieffer, 1922, Ann. Soc. ent. France, 91 : 10.

Microtendipes tenuimanus Kieffer, I922, ibid. 91 : II (sYN. Nov.).

Microtendipes pallidinervis Kieffer, I922, ibid. 91 : I5 (SYN. NOv.).

Thorax reddish yellow, with a darker lateral stripe on the pleuron, abdomen dark brown, wings and legs unmarked, cross-vein unusually long, appendage I of male hypopygium bilobed. This is another species resembling fuscipenne but it is readily distinguished by the absence of frontal tubercles, by the plain legs and by the male hypopygium.

Male. Wing length $2-3 \mathrm{~mm}$.

Head and mouthparts yellowish brown, antennae with dark plumes, A.R. $2 \cdot 75$, eyes well separated, frontal tubercles absent. Thorax reddish yellow, shoulders whiter, pleura with a horizontal dark stripe, postnotum brown, dorso-central bristles pale and uniserial. Legs yellow, apices of anterior femur and tibia vaguely darkened, scale triangular and with short spur, L.R. 2.5, anterior tibia hardly more than twothirds length of femur, tarsus not bearded. Wings plain, cross-vein unusually long, more or less horizontal, halteres blackish. Abdomen dark brown; hypopygium (Text-fig. 3, g) with conical IXth tergite carrying a short, narrow anal point, styles stout, appendage I bilobed, appendage 2 short and with a longer hair at the apex.

Female resembles male, though thoracic stripes are partially darkened in some specimens.

All the type material is lost, all three were described from French CAMERoons : Kribi. It is not clear from the original description whether the female described by Kieffer as longinervis really belongs to this species or not; it is however, quite certain that the male described as longinervis and the female as temuimanus are the opposite sexes of the same species, whilst the male placed in pallidinervis also appears to be the same. 
Distribution. Belgian Congo: 2 ô, I 올. Eala, iv-v. I936 (J. Ghesquière) ; I $\delta^{\hat{D}}$, Equateur, Flandria $(R \cdot P$. Hulstaert $) ; 4 \hat{0}, 9$ ㅇ, Elisabethville, xii. I938-iv. I939 $(H . J . B r e ́ d o)$. The type locality is additional.

\section{Polypedilum (Polypedilum) subconfluens Kieffer}

Microtendipes subconfluens Kieffer, I922, Ann. Soc. ent. France, 91 : 9.

This species was described by Kieffer from a single female which is now lost; I have a second female which has tarsi and wings broken and for this reason I am not absolutely certain of the genus. However, it bears a resemblance to fuscipenne and so I am placing it here until more material of both sexes becomes available; it certainly does not belong to Microtendipes as now defined. Thorax yellow, with black markings anteriorly and around the wing bases; eyes almost touching on the vertex; anterior tibia black, scale with a sharp spur.

Female. Length 3-4 mm.

Head dark brown, palpi yellow and rather long, antennae with 6 segments, apical segment two and half times as long as fifth; eyes large, the narrow upper portions wider than usual and almost meeting on the vertex. Thorax mainly yellowish and shining but with blackish markings anteriorly, around wing bases including part of lateral stripes and on postnotum; dorso-central bristles short, pale and uniserial. Legs yellow, anterior tibiae completely and anterior femora partially black, scale triangular and with sharp spur, anterior tibia hardly three-quarters length of femur which appears rather long; combs of other legs partially fused, spur short. Wings plain, unmarked; halteres yellow. Abdomen dark brown, yellowish on segments I and 7-9 in the single specimen available to me.

Holotype female lost, locality not given in the original description.

Distribution. Nigeria: I , Abuja, xii.I954 (R. W. Crosskey).

\section{Polypedilum (Polypedilum) bifalcatum Kieffer}

Polypedilum bifalcatum Kieffer, I92 I, Ann. Soc. sci. Brux. 41 (I) : 99 ; Kieffer, I922, Ann. Soc. ent. France, 91 : 26.

Thorax brown or pale brown with variable darker markings, abdomen blackish or dark brown. Very similar to a number of other plain-winged species and only to be recognized with certainty by the structure of the male hypopygium, especially by the bent and tapered appendage $I$.

Male. Wing length $\mathrm{I} \cdot 5 \mathrm{~mm}$.

Head and mouthparts brown, pedicel often paler, antennae brown, A.R. about I.6. Thorax brown, often pale brown and with darker markings along the hair lines and on the pleura, dorso-central bristles uniserial. Legs brownish, anterior pair darker, L.R. about $\mathrm{I} \cdot 8$, scale oval and with a short spur. Wings unmarked, halteres yellow. Abdomen dark brown or blackish; hypopygium (Text-fig. 4, a) with appendage I strongly developed, bent and tapered near the middle to a narrow apex which is directed transversely, styles rather wide.

Female similar to male in colour. 
Holotype male lost, type locality Sudan : Shambe.

Distribution. Sudan: long series of both sexes at light, Yirol, vi-vii and xii.I954 (E. T. M. Reid). Nigeria: 2 ô, Kankiya, vii-x.I956 (B. McMillan). Belgian Congo: long series of both sexes at light, Elisabethville, iv. I939 and Maka Lualaba, i.I939 (H. J. Brédo).

\section{Polypedilum (Polypedilum) laterale Goetghebuer}

Polypedilum laterale Goetghebuer, 1936, Rev. Zool. Bot. Afr. $28: 487$.

? Kribiophilus calcaratus Kieffer, 1922, Ann. Soc. ent. France, 91 : 44.

Mesothorax yellowish, prescutellar area or part of it and a horizontal pleural stripe blackish, abdomen black, legs yellow, L.R. $2 \cdot 5-3 \cdot 0$, wings unmarked, appendage I of male hypopygium curved and pointed. Separated from other plain-winged species by the hypopygial structure and the thorax colour. From the description and figure it seems likely that $K$. calcaratus is an earlier description of this species; it certainly belongs to Polypedilum because the VIIIth tergite of the male is narrow basally ; the colour is rather darker, but more material may show that it is variable in this respect.

Male. Wing length $\mathrm{I} \cdot 6-\mathrm{I} \cdot 8 \mathrm{~mm}$.

Head yellow, mouthparts brown, antennae dark, A.R. about I 8 , dorsal narrow portion of the eyes rather narrower than is usual. Thorax mainly yellowish; pleura with a broad horizontal black stripe, postnotum and scutellum partially black ; further black markings present in prescutellar area either as a central triangular mark extending forwards as a line along line of acrostichal bristles, or as a more vague area which may be extended along lines of dorso-central bristles. Legs yellow and unmarked, though the anterior knees and tibiae may sometimes be darker; anterior tibia short, hardly more than half length of femur, L.R. $2 \cdot 5-3 \cdot 0$, scale narrow and pointed. Wings unmarked, halteres with black knobs. Abdomen blackish; hypopygium (Text-fig. 4, b) with anal point at apex of conical extension of IXth tergite, appendage I curved and pointed, appendage 2 somewhat reduced, styles blunt.

Female resembles male.

I have seen the holotype male of laterale in Musée Royal du Congo Belge, Tervuren ; the type of calcaratus is lost (type locality French CAMERoons : Kribi).

Distribution. SUdAN: I 옹 Amadi and I 우, Yirol, vi-vii.I953 (E. T. M. Reid). French West Africa, Haute Volta : I $\delta^{\star}, 2$ 우, nr. Bobo Dioulasso, ix. 1956 (J. Hamon). Belgian Congo: holotype male and two other males, Chambi, escarp. Kabasha; I ô, Ituri, Kasenyi, ii.I953 (J. Verbeke). N. Rhodesia: I $\hat{0}$, Lower Luangwa River, ix. IgIo (S. A. Neave). Natal: I $\hat{0}$, Tugela River, Drakensburg, ix.I953 (A. D. Harrison).

\section{Polypedilum (Polypedilum) ephippium sp. n.}

Thorax dark brown, wings plain, segments I-5 of abdomen yellow, segment 3 with a black mark; male appendage I stout basally and bent ; easily distinguished from bifalcatum and others with bent appendage I by the abdominal pattern. 
Male. Wing length $2 \mathrm{~mm}$.

Head and mouthparts brownish yellow, antennae pale, A.R. I·75. Thorax dark brown and slightly pruinose, scutellum paler. Legs yellow and unmarked, anterior tibia three-quarters length of femur, scale oval and with a short spur at apex,

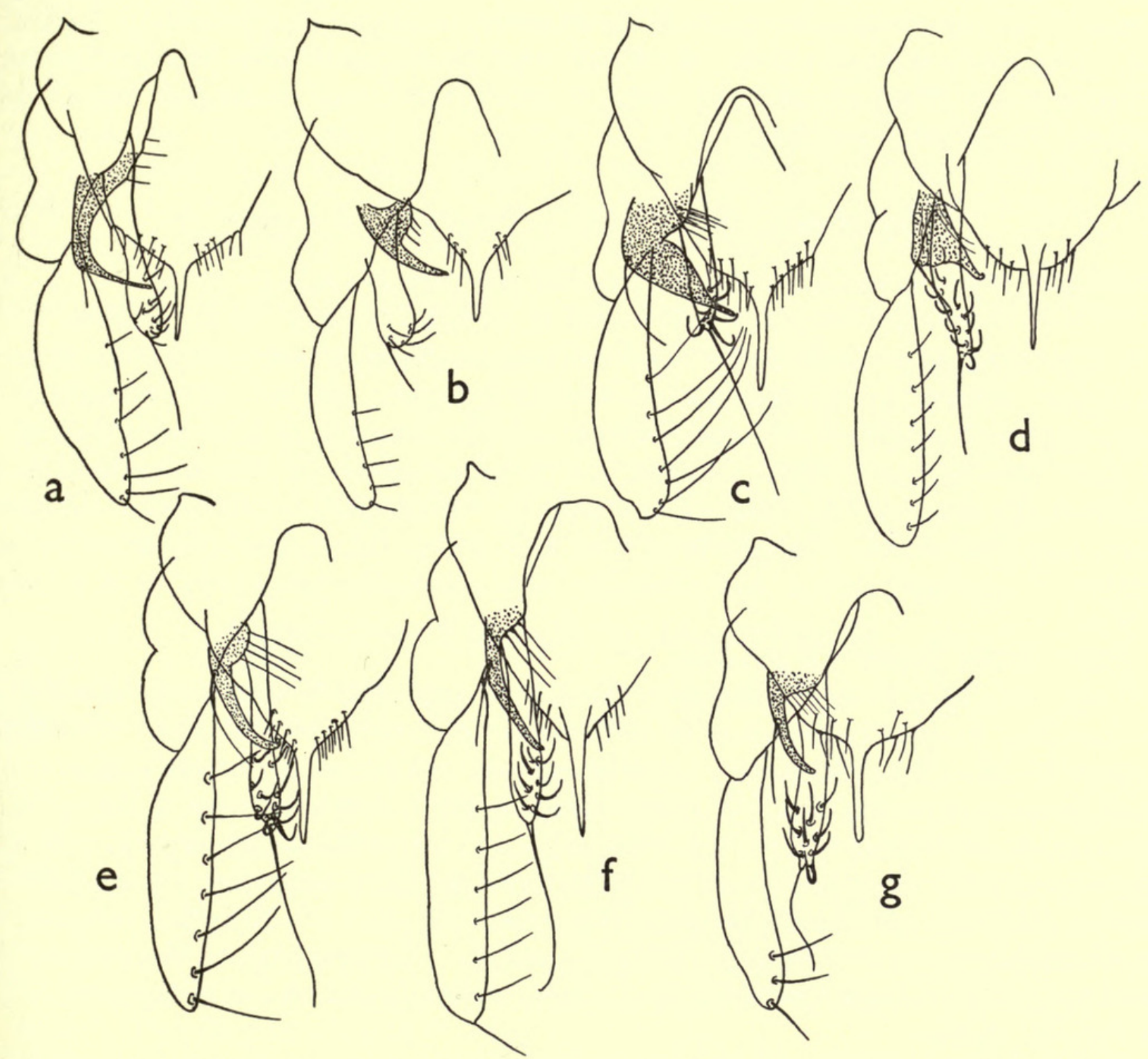

FIg. 4. Male hypopygia of Polypedilum (Polypedilum). (a) P. bifalcatum;

(b) P. laterale; (c) P. ephippium; (d) P. annulatum; (e) P. brunneicornis;

(f) P. bipustulatum; (g) P. melanophilus.

anterior tarsi all broken, spur of posterior tibia long and slender. Wings unmarked, halteres yellow. Abdomen with segments I-5 whitish yellow, segment 3 with a central saddle-shaped black mark, occasionally incisures are darker, segments 6-8 black, styles pale. Hypopygium (Text-fig. 4, c) variable; in the holotype from which figure is drawn, appendage I stout and bent near the middle, tapering to a narrow apex; in other specimens the narrow portion commences at the bend and 
in still others the whole appendage is shorter; appendage 2 narrow, apical hair long, styles with long inner hairs.

Female not known.

Holotype male and paratype I 9 , S. Rhodesia : Salisbury, ii-iii.I956 (E. T. M. Reid) ; further paratypes, same locality and collector, I $\hat{\sigma}, \mathrm{ix}-\mathrm{x} . \mathrm{I} 954$ and $3 \hat{\delta}$, iv. I956. Belgian Congo: I đ̃, Elisabethville, ii. I939 (H. J. Brédo). Sudan: I ô, Mvolo, vi-vii.I954 (E. T. M. Reid). All specimens in the British Museum except for the Elisabethville one which has been returned to Institut Royal des Sciences Naturelles, Bruxelles.

\section{Polypedilum (Polypedilum) kibatiense Goetghebuer}

Polypedilum kibatiense Goetghebuer, 1936, Rev. Zool. Bot. Afr. $28: 487$.

Polypedilum stilatum Freeman, 1955, Explor. Parc nat. Albert Miss. de Witte, 83 : 29 (syn. Nov.).

Wings unmarked, body colour usually pale, sometimes with darker markings on thorax, halteres and at apices of abdominal segments. Most easily distinguished from other species except annulatum by the broader appendage I of the male hypopygium with its narrow beak; separated from annulatum by the absence of pale bands at the apices of the abdominal segments. Examination of the type of kibatiense has shown that stilatum is a synonym. The Palaearctic species convictus Walker is extremely similar and kibatiense may eventually prove only to be a form of this.

Male. Wing length $\mathrm{I} \cdot 6-2 \cdot 0 \mathrm{~mm}$.

Head, mouthparts and antennae yellowish or yellowish brown, A.R. about I.5. Thorax may be pale yellowish with stripes hardly darker and shoulders whitish or it may be of a browner tinge; postnotum and a horizontal pleural stripe often blackish or dark brown, but both may be pale in the palest specimens. Legs yellow or brownish, unmarked; L.R. I.8, scale oval, spur scarcely distinguishable. Wings quite unmarked, halteres normally dark, but specimens with the knobs pale do occur. Abdomen usually plain greenish or yellowish, but in some specimens there are narrow dark rings at the apices of the segments. Hypopygium not distinguishable from that of annulatum (Text-fig. 4, $d$ ), appendage I broad and with an inner beak of variable shape.

Female not always recognizable with certainty as it is very similar to females of other pale species; where associated females are available they are very similar to the male.

I have seen the holotype male of kibatiense in Musée Royal du Congo Belge, Tervuren, type locality Belgian Congo: N. Kivu. The holotype of stilatum is in the collections of the Institut des Parcs nationaux du Congo Belge, type locality Belgian Congo: Rutshuru.

Distribution. Sudan: I $\widehat{\delta}$, I 9 , Yirol, xii.r954 (E. T. M. Reid). Uganda: I $\hat{\jmath}$, L. Victoria $(W . W$. Macdonald $)$. Belgian Congo: $8 \hat{\jmath}, 20$ 우, Maka Lualaba, i.I939 (H. J. Brédo); I ô, Elisabethville, iii.I939 (H. J. Brédo). S. Rhodesia : 2 б, Mt. Chironda (C. F. M. Swynnerton); I đ, Salisbury, iv. I956 (E.T.M. Reid). Natal: I $\widehat{\jmath}$, Mooi River, Kamberg Game Reserve, ix.I953 (A. D. Harrison). 


\section{Polypedilum (Polypedilum) annulatum Freeman}

Polypedilum annulatum Freeman, 1954, Proc. R. ent. Soc. Lond. (B) $23: 22$.

This species is only doubtfully distinct from kibatiense. The main point of difference lies in the colour, which is considerably darker, most specimens being dark brown, but it is quite usual for the thorax to be paler than the abdomen. The abdomen is ringed, each segment having a pale or pruinose apical band occupying about one-third of the segment. The halteres are always pale, but the thorax may have an indication of a darker pleural stripe. Male hypopygium (Text-fig. 4, $d$ drawn from holotype) of same form as kibatiense, but quite variable and appendage I may be much broader with the "beak" placed centrally. It is not possible to define the species on the exact shape of appendage I because so many variations exist, although in all of them the base is broad and the apex beak-like.

Holotype male in the British Museum, type locality CAPE Province : Kirstenbosch.

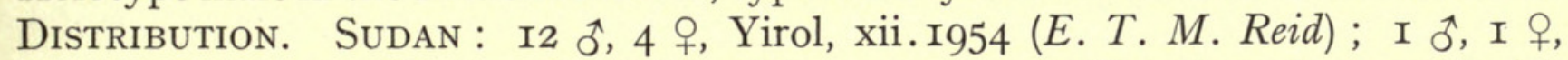
Amadi, vi-vii.r954 (E. T. M. Reid). Nigeria: 2 oै, Kankiya, ix-x. I956 (B. McMillan). SÉnÉGAL: I $\widehat{\jmath}, \mathrm{nr}$. Dakar, ii.I954 (J. Hamon). Belgian Congo: II $\hat{o}$, I o, Elisabethville, xii. I938 (H. J. Brédo). CAPE Province : I ô, I q, Wellington, xi.I955 (K.M.F.Scott) ; I đै, Berg River, xii.I952 (K. M. F. Scott).

\section{Polypedilum (Polypedilum) brunneicornis Kieffer}

Chironomus brunneicornis Kieffer, I9I I, Trans. Linn. Soc. Lond. (Zool.) $14: 352$.

Chironomus pandani Kieffer, I9I I, ibid. 14 : 356 (sYN. Nov.).

A small yellowish brown species without conspicuous markings on body or wings ; A.R. I·6, L.R. 2 or nearly so, halteres dark, posterior tibial spur long and straight, male hypopygium of simple type, appendage I narrow and curved. It is not easy to distinguish this species from other similar ones, but the antennal and hypopygial proportions differ from those of melanophilus whilst dewulfi and vanderplankei are darker and have pale halteres. From examination of the type series it appears that Kieffer described the female under the name brunneicornis and the male as pandani.

Male. Wing length $\mathrm{r} \cdot 8 \mathrm{~mm}$.

Head, mouthparts and antennae yellowish, A.R. I.6. Thorax with whitish yellow background; stripes, sternopleuron and postnotum reddish or brownish yellow. Legs uniformly yellowish, L.R. 2 or nearly so, scale more or less triangular and with very small spur, spurs of posterior legs rather long and straight. Wings unmarked, halteres with dark knobs. Abdomen yellowish green, unmarked; hypopygium (Text-fig. 4, e) simple; anal point well formed, appendage I narrow and curved, appendage 2 with long apical bristle, style of medium width, inner bristles long.

Female similar to male in colour.

C. brunneicornis was described from four female cotypes from Seychelles: Mahé, two of which are in the British Museum ; I have labelled one of these lectotype. Kieffer described pandani from eight males from the same locality, four are in 
the British Museum and I have again labelled one as lectotype. No other specimens are known.

\section{Polypedilum (Polypedilum) melanophilus Kieffer}

Chironomus melanophilus Kieffer, I9II, Trans. Linn. Soc. Lond. (Zool.) 14 : 355.

Chironomus limnocharis Kieffer, I9II, ibid. 14: 357 (sYN. Nov.).

Chironomus nocticolor Kieffer, I9II, , ibid. $14: 357$ (SYN. Nov.).

Polypedilum brunneum Freeman, 1954, Proc. R. ent. Soc. Lond. (B) 23 : 178 (syn. Nov.).

Superficially this species resembles brunneicornis but it differs as follows : size smaller (wing length $\mathrm{I} .5 \mathrm{~mm}$.), colour darker, being brown rather than yellow, A.R. only $0 \cdot 5$, styles of male hypopygium narrow (Text-fig. $4, g$ ) and with a much less complete row of hairs, appendage I smaller, apical hair of appendage 2 shorter. It is quite possible that this is only a smaller form of brunneicornis but it is preferable to keep them separate until there is more information on the limits of the species in the genus.

C. melanophilus was described from a single female from Seychelles: Mahé, in the British Museum. There are four cotypes males of limnocharis, two being in the British Museum, one of which I have marked as lectotype, type locality Seychelles: Mahé. C. nocticolor was described from two female lectotypes from the same locality, both are in the Cambridge University Museum and I have marked one as lectotype. There is no real difference, other than sex, between any of these three species and they seem to be indistinguishable from material which I described as brunneum (type locality CAPE PROVINCE: Hermanus Waterfall)-type series in the British Museum. I have seen no other material which I can definitely associate with this species.

\section{Polypedilum (Polypedilum) glabripennis Kieffer}

Tanytarsus glabripennis Kieffer, I9I I, Trans. Linn. Soc. Lond. (Zool.) 14 : 359.

It is not clear why Kieffer placed this tiny species in Tanytarsus as he states that the wings are bare, that the cross-vein is oblique and that there are only two hypopygial appendages. The species was described from both sexes but only a single female remains which I now fix as lectotype. It seems to belong to Polypedilum, although the pulvilli are not very large and is probably close to melanophilus. It is small and yellow and has $R_{4+5}$ curved and rather widely separated from $R_{1}$. The following description is based on the original supplemented from the lectotype.

Wing length of female $\mathrm{r} \cdot \mathrm{O} \mathrm{mm}$.

Yellowish in colour, thoracic markings reddish. Male antennae said to be I2segmented, A.R. not known, of female 6-segmented. Legs yellow, L.R. 2, posterior tibial combs with a single strong spur, combs separate, no tarsal beard. Wings bare, $R_{4+5}$ with well-developed hairs, curved and unusually widely separated from $R_{1}$; $R_{2+3}$ ending practically in contact with $R_{1}$, posterior fork distal to cross-vein which is oblique, squama with at least a partial fringe; halteres dark. Judging from the figure, male hypopygium very similar to that of melanophilus.

Lectotype female in the British Museum; type locality Seychelles: Mahé. No other specimens are known. 


\section{Polypedilum (Polypedilum) dewulfi Goetghebuer}

Polypedilum dewulfi Goetghebuer, 1936, Rev. Zool. Bot. Afr. $28: 484$.

Polypedilum scotti Freeman, 1954, Proc. R. ent. Soc. Lond. (B) 23 : 2 I ; Freeman, 1955, Explor.

Parc nat. Albert, Miss. de Witte, 83 : 26 (syn. Nov.).

This species is very similar indeed to brunneicornis and has identical hypopygial structure (Text-fig. 4, e), except that in some specimens-described as scotti-the styles are rather wider. In size it tends to be larger, wing length as much as $2 \cdot 3$ $\mathrm{mm}$., and the colour is browner, but the halteres are pale; in most specimens the posterior tibial spur is shorter and not as conspicuous as in brunneicornis. Further material from Seychelles may show whether the two species are really to be considered distinct.

I have seen the male holotype of dewulfi in Musée Royal du Congo Belge, Tervuren (type locality BeLGIAN Congo : Rutshuru) and find that scotti cannot be maintained as a distinct species. The holotype of the latter is in the British Museum (locality CAPE Province: Wellington).

Distribution. Sudan : 5 ô, Khartoum, x.I95I (D. J. Lewis) ; 2 ô, Shambe, xi.I953 (E. T. M. Reid). Nigeria: 2 ô, Kankiya, x.I956 (B. McMillan). Belgian Congo: long series from Parc National Albert; 3 ot, Eala, ix. I936 (J. Ghesquière); 7 ô, Elisabethville, xii.I938-iii.I939 (H. J. Brédo). Natal: 3 oै, 6 o , Weenen, iii.I924 (H. P. Thomasset) ; 5 ô, Natal National Park, v. I954 (W. D. Oliff). Cape Province : long series from Berg River (K. M. F. Scott).

\section{Polypedilum (Polypedilum) vanderplanki Hinton}

Polypedilum vanderplanki Hinton, I951, Proc. Zool. Soc. Lond. 121 : 378.

In general structure this species is indistinguishable from brunneicornis and deroulfi, the male hypopygium is also identical. However, the colour is a much darker brown on both thorax and abdomen, whilst the legs are whitish yellow; the halteres are pale. In addition the front tibial scale carries a long black spur as long as the scale itself. The female is very similar to the cotype females of Paratendipes tavetanus which I have seen in the Muséum National d'Histoire Naturelle, Paris (see at head of subgenus), but with the difficulties of comparing and distinguishing female specimens, especially when one lot is in spirit, I prefer not to synonymize them at this stage.

Holotype male in the British Museum (locality Nigeria: Anara, 20 miles SE. of Kadua).

The type series were bred from larvae found in mud in holes in rock and have been shown by Hinton to be capable of withstanding drying for 18 months, they can be alternately dried and re-activated in water a number of times and they can tolerate temperatures of $4 \mathrm{I}^{\circ} \mathrm{C}$. No other specimens which can reliably be identified as belonging to this species are known to me. 


\section{Polypedilum (Polypedilum) bipustulatum sp. n.}

Colour uniformly yellowish except for two dark rounded spots, one on each side of the middle of the mesonotum at the anterior ends of the lateral stripes; halteres and often postnotum also, dark; male styles long and of even width, appendage I narrow. Very similar to dewenlfi but the colour pattern seems sufficient to separate it.

Male. Wing length $\mathrm{I} \cdot 8-2 \cdot 6 \mathrm{~mm}$.

Head and mouthparts yellow, antennae may be more brownish, A.R. about I.8. Thorax yellowish or reddish yellow, anterior ends of lateral stripes dark brown or blackish, together forming a pair of dark rounded spots near the middle of the mesonotum, postnotum also darker in many specimens but not always as dark as the spots. Legs yellow, L.R. I.5, scale triangular and sharp at the apex. Wings unmarked, halteres with black knobs. Abdomen yellow or greenish and without darker markings; hypopygium (Text-fig. $4, f$ ) very similar to dewulfi but appendage I very narrow and styles appear longer and of more uniform width.

Female similar to male in pattern, but thoracic stripes may be brownish.

Holotype male SudAN: Amadi, vi-vii.I954 (E. T. M. Reid). Paratypes: SudAN: I ㅎ, 2 우, Adok, Shambe and Melut, xi.I953 (E. T. M. Reid) ; I ô. Juba, vi-vii.I954 (E. T. M. Reid). Nigeria: 2 ㅇ, Abuja, xii.I954 (R. W. Crosskey);

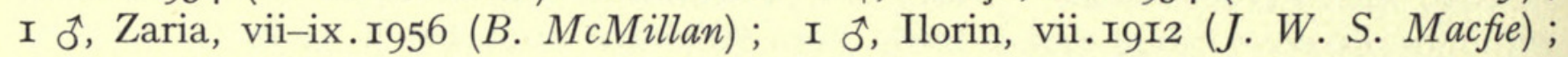
I + , Onitsha (T. J. Anderson). Belgian Congo: I2 ô, 6 o, Maka Lualaba, i. I939 (H. J. Brédo); I ô, Musosa, xi.I939 (H. J. Brédo); 6 ô. 3 우, Elisabethville (H. J. Brédo) ; 2 ô, Eala (J. Ghesquière). Holotype and I8 paratypes in the British Museum, remainder of series returned to Institut Royal des Sciences Naturelles de Belgique.

\section{Polypedilum Kieffer Subgenus Pentapedilum Kieffer}

Pentapedilum Kieffer, 1913, Bull. Soc. Hist. nat. Metz, 28:25; Kieffer, 1923, Ann. Soc. ent. France, 92: 166; Goetghebuer, 1938, in Lindner, Flieg. Pal. Reg. 3 (г3c): 77 ; Freeman, 1954, Proc. R. ent. Soc. Lond (B) 23:22; Freeman, 1955, Explor. Parc Nat. Albert, Miss. de Witte, $83: 30$.

Tanytarsus Kieffer, 1913, Voy. All. Jean. Afr. Or. Ins. Dipt. $1: 24$ (in part).

Rosenia Kieffer, I921, Ann. Soc. sci. Brux. 40 (I) : 275; Kieffer, 1921, Ann. Soc. ent. France, $90: 34$; Kieffer, I923, ibid. $92: 167$ (syn. Nov.).

? Kribiopelma Kieffer, I92 I, ibid. $90: 34$; Kieffer, I923, ibid. 92 : 168.

Pentapedilum subg. Pentapedilum Edwards, 1929, Trans, ent. Soc. Lond. $77: 376$.

Chironomus subg. Pentapedilum Edwards, I931, Dipt. Pat. S. Chile, $2: 3$ ro.

Polypedilum subg. Pentapedilum Townes, 1945, Amer. midl. Nat. 34 : 6r.

This subgenus differs from the typical subgenus only by the presence of macrotrichia on the wing membrane, at least at the apex. I have seen specimens of eight species which I am able to key and describe. In addition Kieffer has described three other species with hair on the wing membrane, two certainly and one doubtfully falling into this subgenus and on which I am giving the following notes.

Pentapedilum kribiense Kieffer, I923, Ann. Soc. ent. France, 92: I66. Described from a yellowish female $\mathrm{I} \cdot 8 \mathrm{~mm}$. long from French Cameroons : Kribi, type probably lost. It is not possible to identify this from the description beyond the genus. 
Rosenia pallida Kieffer, I923, Ibid. 92 : I67. Genus monotypic; described from a whitish male from Kribi, I.5 mm. long. He mentions that the cross-vein is oblique, anterior tibia spurred, segment 8 narrow basally and hypopygium with two appendages. This causes Rosenia to fall as a synonym of Pentapedilum. The species is impossible to identify with certainty but it may be an earlier description of micra sp. n.

Kribiopelma albida Kieffer, I923, ibid. 92: I68. Genus monotypic; described from a whitish female, length $\mathrm{I} \cdot 5 \mathrm{~mm}$. from Kribi. It is impossible to do more than query this as a species of Pentapedilum. It is unlikely to be Tanytarsus because the cross-vein is oblique, but genera and species of these groups based on females alone which are now lost are virtually impossible to determine satisfactorily.

\section{Key to African Species of Polypedilum Subgenus Pentapedilum}

(Based on male characters)

I. Macrotrichia of wing membrane confined to apices of cells $R_{4+5}$ and $M_{1+2}$, none in posterior fork cell

Macrotrichia more numerous, present at least at apex of fork cell

2. Anal lobe of wing absent (Text-fig. 5, $a$ ), halteres black

Anal lobe well developed (Text-fig. 5, b), halteres yellow

3. Abdomen with broad dark bands at bases of segments

If bands are present then they are narrow and apical .

4. A very small species, wing length $0 \cdot 8-\mathrm{I} \cdot 0 \mathrm{~mm}$., wings cuneiform (Text-fig. $5, d$ ), anal point simple

. micra sp. n.

Wing length at least $\mathrm{I} \cdot 75 \mathrm{~mm}$., wings not cuneiform or else anal point with lateral teeth causing it to appear trifid

5. Anal point of male trifid, not unlike Polypedilum (Polypedilum) tridens (Text-fig. 2, g)

Anal point without lateral teeth

kijabensis nom. nov.

6. Macrotrichia reduced, only present at apex and with $3^{-5}$ in fork cell

Macrotrichia present over most of surface, numerous in fork cell .

7. Anal point narrow, as in calvescens (Text-fig. 5,e), appendage I normal.

hamoni sp. n.

wittei Freeman

Anal point very broad, appendage I reduced (Text-fig. $5, f$ )

anale Freeman

\section{Polypedilum (Pentapedilum) ruandae Freeman}

Pentapedilum ruandae Freeman, 1955, Explor. Parc Nat. Albert, Miss. de Witte, 83 : 30.

Dark brown or blackish, abdomen plain; male distinguished from other African species by reduction of macrotrichia on wing membrane, present only on apical half, none present in fork cell ; female with macrotrichia in all cells, but sparsely and only as a single line in base of basal cell, it is darker than wittei.

Male. Wing length $2.75 \mathrm{~mm}$.

Head, mouthparts and palpi dark brown or blackish, A.R. about I·75. Thorax dark brown or blackish with some pruinosity, scutellum may be pale. Legs uniformly dark brown, anterior tibial scale triangular, spur well formed, L.R. about $\mathrm{I} \cdot 4$. Wings unmarked, macrotrichia present only on apical half, confined to cell $\mathrm{R}_{5}$ and apex of cell $\mathrm{M}_{2}$, absent from fork cell and anal cell ; anal region 
reduced so that wing narrows evenly to the base (Text-fig. 5, a). Halteres black. Abdomen black with some pruinosity; hypopygium of a simple type similar to that of calvescens (Text-fig. 5,e).

Female differs from male in the broader wings with denser macrotrichia which are to be found over most of the wing surface posterior to the radius, but only as a single line in the basal half of the basal cell ; macrotrichia not as dense as in anale.

Holotype male in collection of Institut Royal des Parcs nationaux du Congo Belge.

Distribution. Belgian Congo : type series of $282 \hat{\jmath}, 68$ ㅇ, Ruanda, L. Ngando, 8,000 ft., iii. I935. Cape Province: I ô, 2 ㅇ, Vlei, Cecilia's Drift, ix.I955 (K. M. F. Scott).

\section{Polypedilum (Pentapedilum) calvescens sp. $\mathrm{n}$.}

This species is very similar to a small ruandae in appearance and structure, wing length $2 \cdot 0 \mathrm{~mm}$., but it differs by having yellow legs and halteres, by the enlarged anal area of the male wing (Text-fig. $5, b$ ) and by the reduction of the macrotrichia to a small patch at the extreme apices of cells $\mathrm{R}_{5}$ and $\mathrm{M}_{2}$; male hypopygium of simple type (Text-fig. $5, e$ ). In the female, macrotrichia are present on the membrane of the apical half of cells $\mathrm{R}_{5}, \mathrm{M}_{2}$ and of the posterior fork cell and also around the margin of the apical half of the anal cell.

Holotype male and paratype I ô, Cape Province: Berg River, French Hoek, iii-iv.I955 (K. M. F. Scott), both in the British Museum.

\section{Polypedilum (Pentapedilum) vittatum sp. n.}

Yellowish brown or brown, thoracic markings darker brown, abdominal segments with broad dark bands basally ; wings with anal area moderately developed, macrotrichia more uniform than in calvescens, halteres black. Easily distinguished from other species in the male by the broad bands on the abdominal segments, female almost indistinguishable from wittei.

Male. Wing length $2-3 \mathrm{~mm}$.

Head and antennae brown or yellowish brown, A.R. I·7-2·0, palpi darker. Thorax brown or yellowish brown, stripes, postnotum and parts of pleura dark brown. Legs yellowish, L.R. I.5, tibial scale rounded and with a small inconspicuous spine. Wings (Text-fig. $5, c$ ) with anal lobe moderately developed, macrotrichia evenly but not densely distributed over most of wing, absent from bases of fork cell, anal and basal cells; halteres with black knobs. Abdomen yellowish, segments 2-6 with basal halves or more brown; hypopygium very similar to calvescens anal point perhaps narrower, appendage 2 with a few more hairs.

Female with rather denser macrotrichia, abdomen indistinctly banded, not easy to distinguish from wittei.

Holotype male and paratypes Io ô, 3 ․, S. Rhodesia: Salisbury, iv-v. I956 (E. T. M. Reid). Further paratypes: Uganda: I ô, I + , Kilembe, Ruwenzori Kange, xii.I934-i.I935 (F.W. Edwards); I ₹ै, Muko, Kigezi Province, xii.I934 (E. G. Gibbins). All specimens are in the British Museum. 


\section{Polypedilum (Pentapedilum) wittei Freeman}

Pentapedilum wittei Freeman, 1955, Explor. Parc Nat. Albert, Miss. de Witte, 83 : 30.

A pale yellowish or reddish species, easily distinguished from others by the narrow dark bands at the apices of the abdominal segments and the narrow anal point. These bands were not mentioned in the original description, but closer inspection of the holotype, which is not a very good specimen, reveals their presence.
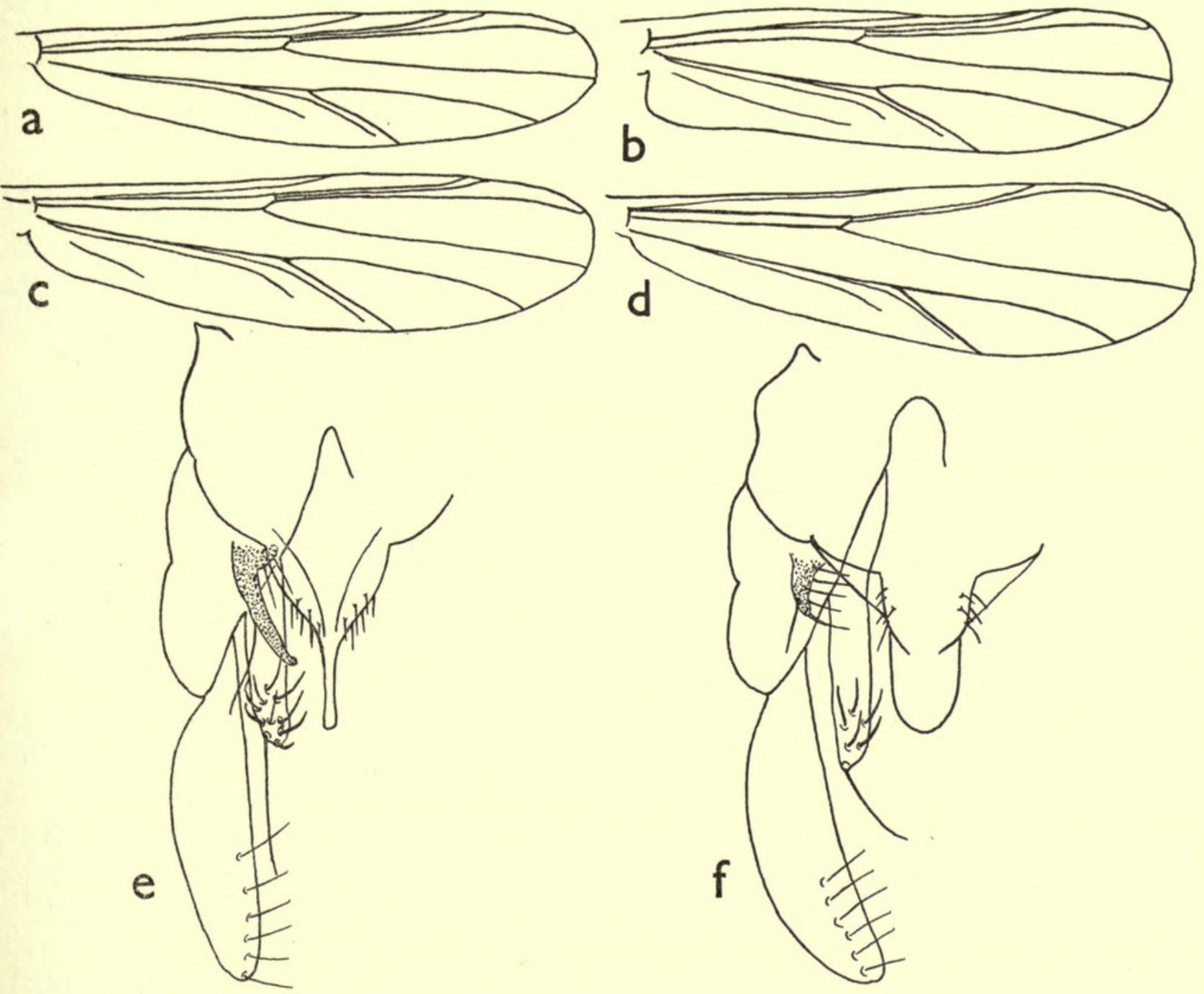

FIG. 5. Wings and hypopygia of males of Polypedilum (Pentapedilum). (a) P. ruandae;

(b) P. calvescens; (c) P. vittatum; (d) P. micra; (e) P. calvescens; (f) P. anale.

Male. Wing length $\mathrm{I} \cdot 75^{-2} \cdot \mathrm{o} \mathrm{mm}$.

Head, mouthparts and antennae yellowish, A.R. 2.0. Thorax yellowish brown with darker brown markings on parts of the pleura and sometimes on the stripes as well. Legs yellowish, without markings, L.R. 2·0, tibial scale with well-formed spur. Wings plain, macrotrichia fairly evenly distributed over most of the wing surface, anal lobe moderate and similar to vittatum; halteres black. Abdomen yellowish, segments I-6 narrowly dark at apices or at the incisures ; hypopygium similar to calvescens, as in vittatum the anal point is possibly finer. 
Female very similar to male, abdomen without markings, rather paler than in female of vittatum.

Holotype male in collection of Institut des Parcs nationaux du Congo Belge (type locality Belgian Congo: Kivu, Kalondo).

Distribution. French West Africa, Haute Volta: 8 $\hat{\jmath}$, Leri $\mathrm{nr}$. Tougan, xi.r954 (J. Hamon). Nigeria : I ô, Katsina, x.I956 (B. McMillan). Sudan : II +, Amadi, vi-vii.I954 and 5 o , 9 ㅇ, nr. Wau, iii.I955 (E. T. M. Reid). Belgian Congo : I3 ô, 22 ㅇ, Maka Lualaba, i.I939 and $9{ }^{\star}, 47$ , Elisabethville (H. J. Brédo), type locality additional. TransvaAl: I $\hat{\delta}$, Kruger National Park, Pretoriuskop and I + , Olifants River, Loskop Dam, v.I955 (A. D. Harrison).

\section{Polypedilum (Pentapedilum) hamoni sp. n.}

Thorax with brown markings, postnotum blackish, halteres with black knobs, abdomen clear green; macrotrichia confined to apex of wings; hypopygium of simple type, anal angle of wing as in wittei. The main features distinguishing this species from wittei are the plain green abdomen and the greatly reduced macrotrichia, the former feature also distinguishes it from ruandae.

Male.-Wing length $2.5 \mathrm{~mm}$.

Head, mouthparts and antennae brown, A.R. 2:5. Thorax yellowish, mesonotal stripes and sternopleuron brown, lateral stripes especially dark, postnotum blackish. Legs yellowish brown, unmarked, L.R. 2·3. Wings with anal angle as in vittatum and wittei; macrotrichia present as a central band in apical half of cell $\mathrm{R}_{\mathbf{4 + 5}}$, as a patch at the extreme apex of cell $\mathrm{M}_{2}$ and as a group of 3-5 at extreme apex of fork cell; halteres with black knobs. Abdomen clear green, without dark markings; male hypopygium of simple type, not unlike that of calvescens sp. $\mathrm{n}$.

Females taken at the same time as the males have macrotrichia more evenly distributed over the apical half and around the anal margin; colour very similar to males.

Holotype male and I3 $\hat{\delta}, 4$ ㅇ paratypes, Belgian Congo: Bukavu, R. Mufuli, 2,400 metres, v.I957 (J. Hamon). Holotype in collection of Office de la Recherche scientifique Outre Mer, Bondy, France; seven paratypes in British Museum.

\section{Polypedilum (Pentapedilum) micra sp. n.}

Distinguished from other African species by its very small size, pale colour and low antennal ratio; wings cuneiform, $R_{2+3}$ indistinguishable, wing membrane evenly covered with macrotrichia, abdomen plain.

Male. Wing length $0 \cdot 8-\mathrm{I} \cdot 0 \mathrm{~mm}$.

Head, mouthparts and antennae yellow, A.R. hardly more than $0 \cdot 6$. Thorax yellowish, stripes brownish, pleura with horizontal dark band. Legs pale and unmarked, tibial scale sharply triangular, L.R. about 2. Wings unmarked, broad apically and more or less cuneiform with reduced anal area (Text-fig. $5, d$ ), $\mathrm{R}_{4+5}$ close to $R_{1}$ and obliterating $R_{2+3}$, posterior fork more distal to cross-vein than in other 
species, macrotrichia evenly distributed; halteres with black knobs. Abdomen plain yellowish; hypopygium similar to calvescens.

Female similar to male.

Holotype male and paratypes 3 o, 3 ㅇ, SudAN: Wunatong, nr. Wau, iii.I955 (E. T. M. Reid). Further paratypes, SudAN : I ô, Amadi, vi-vii.r954 (E. T. M. Reid). Gold CoAst : 4 ô, 2 ㅇ, Kete Krachi, x.I898 (Graf Zech). French West Africa, Haute Volta: I $\delta^{\star}$, Tangrela, nr. Banfora, xii.I956 (J. Hamon). Four paratypes returned to Museum der Universität, Berlin, one to Institut d'Enseignement et de Recherches Tropicales, Bondy, France, holotype and remainder of series in the British Museum.

\section{Polypedilum (Pentapedilum) anale Freeman}

Pentapedilum anale Freeman, 1954, Proc. R. ent. Soc. Lond. (B) 23 : 22 ; Freeman, 1955, S. Afr. Animal Life. Uppsala, $2: 376$.

Typical South African specimens are dark in colour with thorax almost black, but specimens from further north are paler and similar to wittei with darker bands at the abdominal incisures; A.R. I.3, wings with anal lobe reduced and evenly clothed with macrotrichia. Distinguished from all other African species by the broad anal point of the male.

Male. Wing length $\mathrm{I} \cdot 75^{-2} \cdot 0 \mathrm{~mm}$.

Head, mouthparts and antennae black in southern specimens, paler in some northern specimens, A.R. I·3. Thorax in southern specimens blackish and rather shining but it may be brown or paler with reddish stripes in other material. Legs brown or yellowish brown, L.R. I.5-I·75, tibial scale with sharp spur. Wings with anal lobe moderately reduced, similar to vittatum, evenly clothed with macrotrichia, halteres black. Abdomen either very dark and with a greenish tinge or brown and slightly darkened at the incisures; hypopygium (Text-fig. $5, f$ ) with broad and down-turned anal point, appendage I reduced, with long hairs and formed into a narrow spine apically, appendage 2 with few hairs.

Female similar to male, wing macrotrichia rather denser, as usual in this sex.

Holotype male in the British Museum (type locality CAPE Province: Palmiet River, Elgin).

Distribution. Cape Province: type series from Elgin, Muizenberg Mt., Wellington, Bergvliet, Kirstenboch and French Hoek; additional specimens from Cape Peninsular, Tzitzikama Forest and Assegaibos (P. Brinck). Basutoland: Nazareth (P. Brinck). SW. Africa: Kaokoveldt (P. Brinck). TransvaAl: 4 ô, 3 ㅇ, Olifantsvlei, nr. Johannesburg, viii.I954 and 4 ㅅ․, 3 우, Klipspruit, nr. Witbank, iv-v.I956 (A. D. Harrison). S. RhodESIA : 5 ô, 4 + , Salisbury, iv. I956 (E. T. M. Reid). Belgian Congo: I ô, Elisabethville, ii. I939 (J. H. Brédo). Uganda : I ô, I q, Kampala, xi.I929 (G. L. R. Hancock). French West Africa, Haute Volta: I $\hat{\sigma}$, nr. Bobo Dioulasso, xi.I956 (J. Hamon).

Mr. Harrison tells me that in the Transvaal this species is found in streams heavily polluted with industrial effluent containing sulphuric acid strong enough to taste. 


\section{Polypedilum (Pentapedilum) kijabensis nom. nov.}

Tanytarsus alticola Kieffer, 1913, Voy. All. Jean. Afr. Or. Ins. Dipt. 1:25 (not Polypedilum alticola Kieffer, I913, ibid. 1:22-see above).

I have seen the type male of this species and can confirm that it belongs to this genus and not to Tanytarsus, no other specimens are known. It is dark brown, $2.5 \mathrm{~mm}$. long and can be separated from other species of the genus by the anal point of the male which resembles that of Polypedilum (Polypedilum) tridens in having a tooth each side near the base. The name alticola is preoccupied when the species is transferred to Polypedilum.

Holotype male in Muséum National d'Histoire Naturelle, Paris, type locality Kenya : Kijabe, Kikuyu Escarpment.

\section{Genus STICTOCHIRONOMUS Kieffer}

Stictochironomus Kieffer, I919, Ent. Mitteil. 8:44; Freeman, 1955, Explor. Parc Nat. Albert, Miss. de Witte, $83: 24$

Kribiocallis Kieffer, 1921, Ann. Soc. sci.Brux. 40 (1) : 271 ; Kieffer, 1922, Ann. Soc. ent. France,

91 : I6 (sYN. Nov.).

Chironomus subg. Stictochironomus Edwards, 1929, Trans. ent. Soc. Lond. $77: 400$.

Tanytarsus subg. Stictochironomus Townes, 1945, Amer. midl. Nat. 34 : 77.

Antennae of male with I4 segments, of female with 6 segments ; frontal tubercles absent. Pronotum rather more reduced than in Polypedilum but better developed than in Microtendipes; mesonotum often with a small central tubercle or slight hump; dorso-central bristles long and usually uniserial, acrostichals small but usually in a complete double row, occasionally completely absent, not reduced to an anterior group as in Microtendipes. Anterior tibia with an oval scale not armed with a spur ; combs of other tibiae fused and with a single spur on each pair ; pulvilli not split, usually rather small. Wing membrane without macrotrichia, with or without dark markings; squama with complete fringe ; $\mathrm{R}_{2+3}$ distinct and ending well beyond tip of $R_{1}$, posterior fork either at same level as or beyond cross-vein. Eighth abdominal tergite of male not contracted basally, styles often rather narrow, appendage I curved, appendage 2 with or without long apical hair.

In general appearance, the species of this genus approach those of Polypedilum but they cannot be included in that genus because of the more reduced and unsplit pulvilli, the absence of a spur on the anterior tibial scale and by the square shape of the VIIIth tergite of the male. The genus is perhaps to be regarded as an intermediate stage between Polypedilum and Microtendipes.

Townes (I945) suggested an interesting alteration in relationships by placing this genus along with Endochironomus and Tanytarsus (= Pentapedilum subg. Phaenopsectra of Edwards, I929) as subgenera of a single genus, which took the oldest name, Tanytarsus, following the type fixation of Coquillett, I9Io (see also below, under the genus Tanytarsus). Although this change in relationships may eventually prove correct, I am not sufficiently certain to adopt it and I prefer for the present to consider Stictochironomus as closer to Polypedilum and Microtendipes than to 
any other genera. I have not been able to find any forked bristles at the apex of the styles of the African species similar to those seen by Townes in the North American species.

Of the six species known to me from Africa south of the Sahara, festivus and natalensis are quite typical and have ringed legs and a central thoracic tubercle; caffrarius, puripennis and fusiformis resemble each other but are not very typical of the genus, whilst bisignatus in appearance is more like a species of Microtendipes. However, all show the main generic characters and it is convenient to consider them as all belonging to the one genus.

\section{Key to the African Species of Stictochironomus}

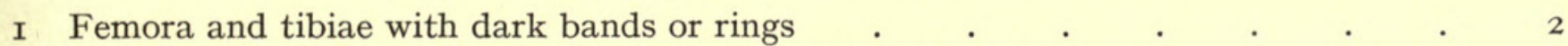

Legs lacking dark bands although knees may be darkened . $\quad$. $\quad$. $\quad$. $\quad$. 4

2. Wings with a dark cloud over cross-vein and no other markings . . natalensis sp. n.

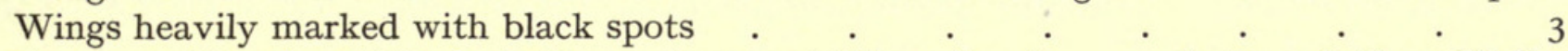

3. Large marking in cell $\mathrm{R}_{5}$ including a clear spot (Pl. 2, fig. a) . festivus festivus Kieffer No clear spot in this marking (Pl. 2, fig. b) . . . festivus imperforatus subs. $\mathrm{n}$.

4. Wings with two broad tansverse dark marking (Pl. 2, fig. $e$ ); knees darkened

Wings either spotted or seamed, knees plain

bisignatus Kieffer

5. Wings with pattern of spots (Pl. 2, fig. c) ; mesonotum with conspicuous silvery pruinosity on lateral stripes . $\quad . \quad$. $\quad . \quad . \quad . \quad . \quad$. caffrarius Kieffer

Wings seamed with grey (Pl. 2, fig. $d$ ) ; mesonotal pruinosity not in form of two conspicuous stripes .

6. Wing length 3-4 mm., thoracic pruinosity less strong and more in form of spots

Wing length $\mathrm{I} \cdot 5^{-2} \cdot \mathrm{O} \mathrm{mm}$., pruinosity stronger and more uniform .

puripennis Kieffer . fusiformis Kieffer

\section{Stictochironomus festivus festivus Kieffer}

Stictochironomus festivus Kieffer, I92I, Ann. Soc. ent. France, 90 : 54.

Kribiocallis stictoptera Kieffer, I922, ibid. 91 : I7 (sYn. NOv.).

Thorax black, mottled with pruinosity; legs white, heavily ringed with black; wings with distinctive black markings, in the typical subspecies the large spot in cell $R_{4+5}$ includes a clear spot ; abdomen of male greenish yellow on 4 basal segments. The colour and pattern make this species easily distinguishable from all other African ones and enable both of Kieffer's species to be readily recognized and easily synonymized.

Male. Wing length $2-2.5 \mathrm{~mm}$.

Head, antennae and mouthparts black, plumes brown, A.R. about 2.5. Thorax black or very dark brown, conspicuously mottled with pruinose spots, central tubercle distinct. Legs white, strongly marked with black rings ; anterior femur with basal and apical thirds black, central third white with a black ring, other femora with basal third and apical fifth black, central pale part including two dark rings; all tibiae with base and apex broadly black, intervening portion with two narrow black rings ; anterior basitarsus with apex and two intermediate rings black, other basitarsi with apex and a single central ring black; second segment of anterior tarsus 
with a broad central band and broad apical band black, other segments of this and other legs with apices broadly black; L.R. I.5, tarsi thinly bearded. Wings (Pl. 2, fig. $a$ of female) with black markings similar to female, the large mark in cell $\mathrm{R}_{4+5}$ reaches to apex of $\mathrm{R}_{1}$ and includes a pale spot; halteres pale. Abdomen with segments I-4 yellowish green, remainder dark, styles pale, all segments pruinose on apical halves. Hypopygium (Text-fig. 6, a) with long anal point and narrow coxites, appendage I curved and with a long subapical hair, 2 with a long apical hair.

Female, resembles male, antennae rather short, abdomen less clear yellow on basal segments ; one wing of a Gold Coast specimen has the clear spot in the main marking more or less occluded but the markings are not reduced as in the South African subspecies.

I have not seen the types which are probably lost ; festivus was described from both sexes from SudAN: Shambe, stictoptera from a female from French Cameroons: Kribi.

Distribution. Sudan: 2 ô, 5 우, Khartoum, i.I923 (S. Hirst) ; 3 ô, I 우, Khartoum, ii.I952 (D. J. Lewis) ; 6 ô, 3 ㅇ, Wad Medani, ii.I952 (D. J. Lewis); I ㅇ, Tonga, xi.r953 (E. T. M. Reid) ; 2 ô, Liednum nr. Wau, ii-iv.I955 (E. T. M. Reid). Gold Coast : 2 ㅇ, Nangodi, x. 1954 (G. Crisp). Transvaal: I ðૈ, Pongola Settlements, ix.I954 (A.D. Harrison).

\section{Stictochironomus festivus imperforatus subsp. $\mathrm{n}$.}

This is extremely similar to the typical subspecies in colour and structure but differs in two points of pattern : first, the anterior basitarsus lacks the basal intermediate dark ring and sometimes also the more apical intermediate dark ring as well ; secondly, the large spot in cell $\mathrm{R}_{4+5}$ does not include a pale spot (Pl. 2, fig. $b$ ), it and the one behind it in cell $\mathrm{M}_{1+2}$ are distinctly smaller than in the typical subspecies.

These differences seem to warrant at least subspecific separation, but further material from other localities may show either that it is only a local variety or else that a distinct species is present. It is possibly a colder water form, but the specimens from Nelspruit and Letsitele taken in conjunction with the specimen of the typical subspecies from the Pongola Settlements give an overlap about which more information is needed.

Holotype male, Natal: Mooi River, Keate's Drift, ix.I953 (A. D. Harrison).

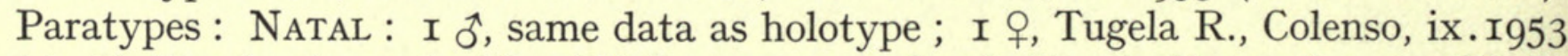
(A. D. Harrison) ; I ô, Albert Falls, x.I953 and 2 우, Tugela R., x-xi.I953 (W.D. Oliff) ; I 우, Mooi R., Keate's Drift, x.I954 (W. D. Oliff); 7 우, Weenen, iii.I924, I , viii.I924, 2 ㅇ, x.I924 (H. P. Thomasset). TRANSVAal: I ô, Nelspruit, iii. I930 (B. de Meillon) ; I ㅇ, Letsitele Valley, iii.I932 (B. de Meillon). All specimens are in the British Museum.

\section{Stictochironomus natalensis $\mathrm{sp} . \mathrm{n}$.}

Thorax more or less mottled, legs with broad but not conspicuous rings, wings with a dark cloud over cross-vein, abdomen of male brown, each segment paler 
and pruinose at its apex. In general appearance not unlike the Palaearctic species $S$. histrio Fabricius, but it may be distinguished by the different arrangement of the leg bands especially the femoral ones.

Male. Wing length $4 \mathrm{~mm}$.

Head, mouthparts and antennae brown, A.R. 2.4. Thorax dark brown, more or less mottled with pruinosity and pruinose between the stripes and around the shoulders; pruinosity not as conspicuous as in festivus, central tubercle present. Legs yellowish, each femur with three broad brown bands, one at the base, one near the middle and one at the apex ; all tibiae with basal third and apex dark, middle and

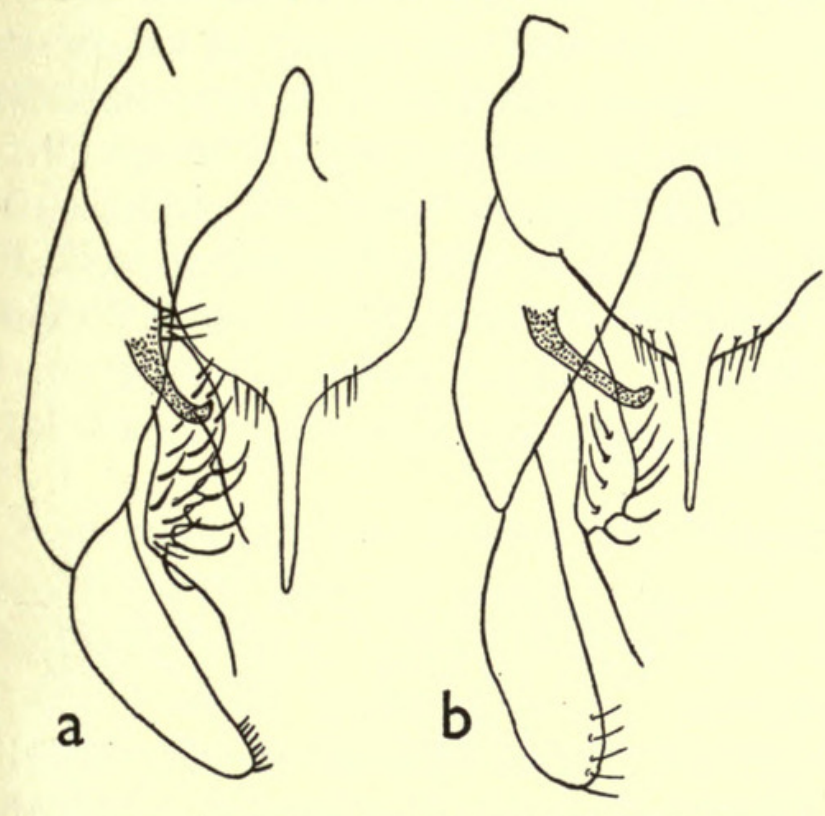

FIG. 6. Male hypopygia of Stictochironomus.

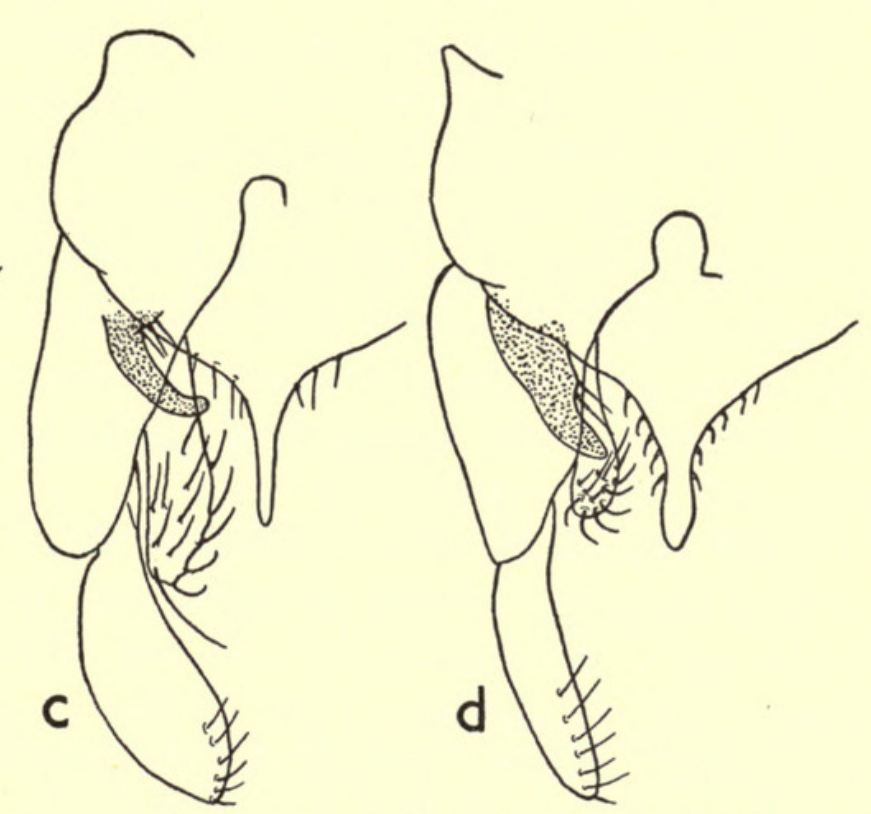

(a) S. festivus festivus; (b) S. caffrarius ;

(c) S. puripennis; (d) S. bisignatus.

posterior tibiae with an additional broad brown band near the middle; all tarsal segments dark at apex, anterior basitarsus with faint central brown band; L.R. about I.I, slight tarsal beard present. Wings unmarked except for a round grey cloud over cross-vein and adjacent veins. Abdomen brown, each segment paler towards the apex, especially laterally, apices of segments pruinose; hypopygium broken.

Female not known.

Holotype male, Natal: Estcourt, ix-x.I8g6 (G. A. K. Marshall) in the British Museum.

\section{Stictochironomus caffrarius Kieffer}

Polypedilum caffrarium Kieffer, I921, Ann. Soc. sci. Brux. 41 (I) : 97 ; Freeman, 1955, Explor. Parc. Nat. Albert, Miss. de Witte, $83: 25$; Freeman, 1955, S. Afr. Animal Life. Uppsala, 2: 377 .

Kribiocharis albipes Kieffer, I922, Ann. Soc. ent. France, $91: 4$.

Polypedilum nilophilus Kieffer, I922, ibid. 91 : 33 (syn. Nov.).

Polypedilum pluriguttatum Kieffer, I922, ibid. 91 : 34 (syn. Nov.).

Polypedilum dampfi Kieffer, 1925, Bull. Soc. R. ent. Égypte, I924: 272 (syn. Nov.).

Polypedilum anuke Kieffer, r935, ibid. 1924 : 275 (syn. Nov.). 
This species is easily recognized by its unringed legs, dark thorax with distinctive pruinose lateral stripes and wings with three or four spots in cell $\mathrm{R}_{4+5}$; there is no central thoracic tubercle and in some ways it is not a typical species of the genus, but it is not sufficiently atypical to warrant the erection of a new genus. I have seen the type of only caffrarius but the wing pattern makes the other species which I have placed in synonymy easily recognizable. It is a wide-spread species and is especially abundant along the Nile.

Male. Wing length $2-2.5 \mathrm{~mm}$.

Head, antennae and mouthparts brown or dark brown, A.R. 2.75. Thorax dark brown or blackish, whole surface slightly pruinose but lateral stripes conspicuously so, especially if examined from behind when they stand out as two broad silvery bands. Legs yellowish white, femora usually darker or brown on basal two-thirds; L.R. I·3, tarsi not bearded, pulvilli practically absent. Wings (Pl. 2 fig. $c$ of female) with pattern of grey spots; cell $\mathrm{R}_{4+5}$ normally with three spots but the apical one may be divided to give four; spots at each angle of fork cell also characteristic; halteres yellowish white. Abdomen dark brown or blackish, sometimes paler laterally especially near the base; hypopygium (Text-fig. 6, $b$ ) with long anal point, appendage I bent near base and apex, appendage 2 with long apical hair, style rounded at tip.

Female similar to male in colour and pattern.

I have seen the cotypes of caffrarium in the South African Museum (type locality TransvaAl: Kaapmuiden); all the other type series are lost. Kieffer described albipes and nilophilus from SUdAN: Shambe; pluriguttatum from FRENCH Cameroons : Kribi ; dampfi and anuke from EGYPT : Cairo and Maadi respectively.

Distribution. Egypt: I ô, Suez Canal, x.I934 (F. W. Edwards). Sudan : numerous specimens from Khartoum and Wad Medani (S. Hirst and D. J. Lewis). Abyssinia: 3 ô. Sagan-Omo, Elolo, viii.I939 (E. Zavattari). Nigeria: I2 ô, Kankiya, x.I956-i.I957 (B. McMillan). BELGIAN Congo: series from Vitshumbi, Kasenyi and Albertville (de Witte and Verbeke) ; 2 ㅇ, Musosa and $2 \hat{\sigma}$, Maka Lualaba (H. J. Brédo). S. Rhodesia : I ô, Salisbury, v.r956 (E. T. M. Reid). Natal: I $q$, Weenen, iii.I924 (H. P. Thomasset). The type localities are additional to these.

\section{Stictochironomus puripennis Kieffer}

Polypedilum puripenne Kieffer, I921, Ann. Soc. sci. Brux. 41 (I) : 97.

Stictochironomus albipes Freeman, 1954, Proc. R. ent. Soc. Lond. (B) $23: 21$.

Stictochironomus puripenne Freeman, 1955, S. Afr. Animal Life. Uppsala, 2 : 378.

A dark brown species with mottled thorax and grey seamed wings, legs not ringed, not unlike caffrarius in general appearance but easily distinguished by plainer wings and absence of strong pruinosity on lateral stripes; most similar to fusiformis but in that species the thorax is more strongly pruinose, and the size smaller.

Male. Wing length 3-4 $\mathrm{mm}$.

Head, mouthparts and antennae dark brown or blackish, A.R. about 2.5. Thorax dark brown or blackish with pruinose mottling and with lines of pruinosity between the stripes, central tubercle present. Legs whitish, femora brown except at apex, 
L.R. I·3, front tarsi with thin beard, pulvilli very small. Wings whitish, veins seamed with grey and with a short grey mark at the apex of cell $\mathrm{R}_{4+5}$ as in fusiformis ; halteres white. Abdomen black, sometimes paler at the base laterally. Hypopygium (Text-fig. $6, c$ ) with appendage I curved, appendage 2 lacking long apical hair, style more or less oval.

Female resembles male.

I have seen the holotype of puripenne which is in the South African Museum (type locality TransvaAl: Kaapmuiden); the holotype male of albipes is in the British Museum (type locality AByssinia: Waldia).

Distribution. Nigeria : I ô, I ㅇ, Zaria, xi. 956 (B. McMillan). Abyssinia : holotype $\hat{\sigma}$ of albipes, Waldia. S. RHODESIA: I $\hat{\sigma}$, I 우, paratypes of albipes, Melsetter ; I ㅇ, Salisbury, iv.I956 (E.T. M. Reid). NATAL: 5 ô, 4 우 and 3 ô, 4 ㅇ, paratypes of albipes, Weenen. CAPE Province : I , paratype of albipes,

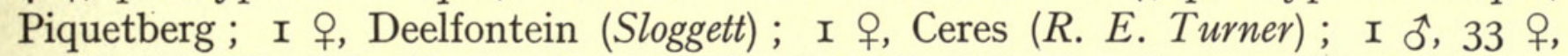
Ladismith $(P$. Brinck); 2 ô, 22 + , Rhodes $(P$. Brinck). Orange Free State: I 우, Zastron (P. Brinck). S. W. Africa : 2 ㅇ, Kaokoveld (P. Brinck).

\section{Stictochironomus fusiformis Kieffer}

Polypedilum fusiforme Kieffer, I921, Ann. Soc. sci. Brux. 41 (I) : 99 ; Kieffer, 1922, Ann. Soc. ent. France, 91 : 30.

Stictochironomus puripenne Freeman, 1957, Mém. Inst. Sci. nat. belg. 8 : I97 (not Kieffer, I921, Ann. Soc. sci. Brux. 41 (I) : 97).

This species is similar to puripennis in colour and structure, although appendage I of the male hypopygium is possibly shorter, but it differs in size (wing length $\mathrm{I} \cdot 5-2.0 \mathrm{~mm}$.) and in the thorax being more uniformly and strongly pruinose; wing pattern (Pl. 2, fig. d) similar to puripennis but perhaps stronger. As a name is available for it, I am retaining it as a distinct species, although it may eventually prove only to be a small form of puripennis.

The holotype female is lost (type locality Sudan: Mongola) but the description leaves no doubt over its identity.

Distribution. Nigeria: I9 ô, 3 o , Kankiya, x.I956 (B. McMillan). Sudan : 5 ô, I ㅇ, Liednum nr. Wau, iii-iv. I955 (E. T. M. Reid). Belgian Congo: 3 s, Albertville, viii. $\operatorname{I953}(J$. Verbeke).

\section{Stictochironomus bisignatus Kieffer}

Chironomus bisignatus Kieffer, 1918, Ann. Mus. nat. Hung. $16: 67$.

Thorax with bluish white pruinosity, legs pale, knees blackish, wings with two broad transverse bands, abdomen yellow, segments I-5 black apically. This is a distinctively coloured and easily recognized species, not very typical of the genus. However, the size of the prothorax, absence of anterior tibial spur and fused posterior combs, suggest that it is best placed here. I have been able to borrow the type and can confirm the identification.

Male. Wing length $2-2 \cdot 5 \mathrm{~mm}$.

ENTOM. 6, II. 
Head brown, palpi darker, pedicel reddish, A.R. about I.5. Thorax reddish brown, postnotum and pleura darker, whole thorax pruinose, pruinosity with a brilliant bluish tinge on shoulders and centrally on the pleura; acrostichal bristles completely absent, central tubercle not developed. Legs yellow, knees and apices of tibiae blackened, L.R. I.75, tarsal beard absent, tibial scale quite large but rounded, pulvilli large. Wings (Pl. 2, fig. $e$ of female) with conspicuous pattern formed of two broad transverse dark bands, usually more or less joined along $\mathrm{M}_{3+4}$ by a fainter grey shadow; halteres dark brown or blackish. Abdomen yellow with dark bands at apices of segments I-5, sometimes encroaching on to bases of succeeding segments, segments 6-9 dark, styles pale. Hypopygium (Text-fig. 6, $d$ ) with narrow styles, appendage I broad, appendage 2 small, anal point stout and fringed with stout bristles as shown.

Female resembles male, abdomen not so clearly marked, antennae probably 6-segmented.

I have seen the holotype male which was in the Hungarian National Museum (type locality Natal: Sarnia).

Distribution. Cape Province: I 9 , Ceres, iv.rg25 (R. E. Turner). Natal: I ㅇ, Kloof, ix. I926 (R. E. Turner). S. Rhodesia : I + , Salisbury, iv. I956 (E.T.M. Reid). Tanganyika: I $\hat{\sigma}$, Njombe, xi.r947 (W. Peters). Belgian Congo: 6 ô, 2 o , Elisabethville, ii.1938, iv.1938 and xii.1938 (H. J. Brédo). Kenya: I ठ̃, Ruiru, vi.I932 (H. C. James).

\section{Genus MICROTENDIPES Kieffer}

Microtendipes Kieffer, I915, Broteria, Sér. Zool. 13 : 70 ; Edwards, 1929, Trans. ent. Soc. Lond. 77 : 396 ; Townes, 1945, Amer. midl. Nat. 34 : 22 ; Freeman, 1955, Explor. Parc Nat. Albert, Miss. de Witte, 83 : 31 (not Kieffer, 1922, Ann. Soc. ent. France, 91 : 8-see Polypedilum). Kribiomimus Kieffer, I921, Ann. Soc. sci.Brux. 40 (I) : 27I ; Kieffer, I921, Ann. Soc. ent. France, $90: 49$ (sYN. Nov.).

Kribiocharis Kieffer, I921, Ann. Soc. ent. France, $90: 29$ (in part).

Hulstaertiella Goetghebuer, 1936, Rev. Zool. Bot. Afr. $28: 456$.

Antennae of male with I4 segments, of female with either 6 or 7 ; frontal tubercles absent. Pronotum reduced, divided in the middle and overhung by mesonotum, much as in Stenochironomus; mesonotum without central tubercle; dorso-central bristles present as a clear row, but acrostichals reduced to a group at the apex of the mesonotal cone. Anterior tibia more or less truncate at the apex, scale not produced at all and no spur present ; combs of other tibiae separate, one spur on each pair ; pulvilli present but often small, not divided longitudinally; anterior femur of male sometimes with a tuft of bristles near the apex pointing towards the base. Wing membrane without macrotrichia, with or without dark markings; squama with complete fringe ; $R_{2+3}$ lying very close to $R_{1}$ apically and often almost indistinguishable from it at the tip, posterior fork either below or slightly beyond cross-vein Male with VIIIth abdominal tergite not contracted basally, styles more or less oval, appendage I curved, 2 without long apical hair.

Microtendipes can easily be recognized by the reduced prothorax and acrostichal bristles, approximation of $R_{1}$ and $R_{2+3}$, presence of only one tibial spur and reduced 
tibial scale. Although superficially resembling Stenochironomus, these characters combined with the quite different male hypopygium render it readily distinguishable.

As explained in I955, I have emended the definition given by Edwards (I929) so as to include African species with patterned wings and 6-segmented female antennae. This causes Hulstaertiella to be a synonym. Kribiocharis (type $K$. filitarsis fixed by Freeman, I955) included five species belonging to at least three genera and possibly more. I have been able to recognize three of these with certainty another with less certainty, and the last one not at all, but I have given a description of it below, taken from the original. Kribiomimus falls as a synonym because the type species, $K$. bifasciatus Kieffer, is a species of Microtendipes. Of the other species placed in Kribiomimus by Kieffer in I92I, one is probably another species of Microtendipes, another falls into Polypedilum and the last seems best placed in Lauterborniella.

Kieffer used the genus Microtendipes in his I92I-22 papers in Ann. Soc. ent. France for ten species with the scale of the anterior tibia pointed or apically setiform. Those that I have been able to recognize are all species of Polypedilum and it is probable that the others belong there too, because of the shape of the scale: they certainly cannot be admitted to Microtendipes as used now. These species are all treated under Polypedilum.

\section{Key to the African Species of Microtendipes}

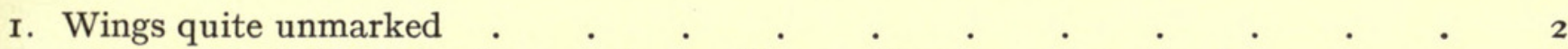

Wings with distinct clouds or spots or with a median transverse cloud . . . . 3

2. Anterior femur only narrowly dark at apex, in male without group of basally directed bristles; thorax green with reddish stripes ; basal halves or more of abdominal segments 2-5 dark . . . . . . . . . . lamprogaster Kieffer

Anterior femur with at least apical third dark, in male group of basally directed bristles present; thorax mainly or entirely black; abdomen of male with segments I-5 unmarked greenish yellow . . . . . . satchelli Freeman

3. Wing markings in form of a faint transverse cloud or with apical half faintly clouded (Pl. 2, fig. $f$ ) . . . . . . . . . . . umbrosus Freeman

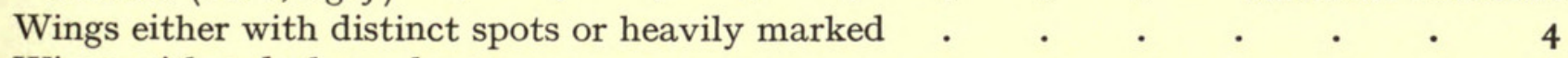

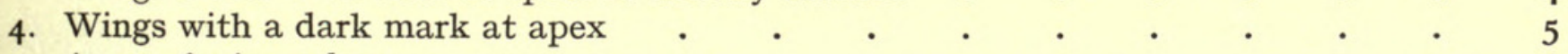

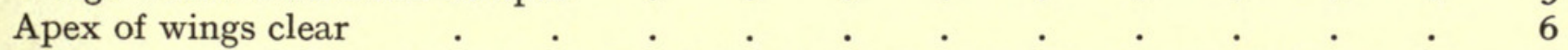

5. Wing pattern in form of numerous small rounded spots (Pl. 2, figs. $i, j$ ) exact arrangement variable . $. \quad . \quad . \quad . \quad . \quad . \quad . \quad$ lentiginosus Freeman

Wing pattern not like this, formed of few discrete spots as in Pl. 2, fig. $g$

6. Wings with seven spots (Pl. 2, fig. h), two being in posterior fork cell . taitae Kieffer

Wing pattern more extensive and not in form of discrete spots $\begin{array}{lllll} & \text {. } & \text {. } & & \\ 7\end{array}$

7. Femora with dark central ring, knees and apices of other segments dark; cell $\mathrm{R}_{4+5}$ either with the basal two-thirds dark or with a pale area in the middle of this dark cloud; pale spot in anal cell well basal to posterior fork (Pl. 2, figs. $k, l$ )

bifasciatus Kieffer

Legs unmarked

8. Wings with a single transverse band which spreads out posteriorly in anal and fork cells. . . . . . . . . . luteipes Kieffer

Wings with two transverse bands connected by a grey tract in cell $\mathrm{M}_{1+2}$

flavipes Kieffer 


\section{Microtendipes lamprogaster Kieffer}

Chironomus (Tendipes) lamprogaster Kieffer, I914, Ann. S. Afr. Mus. 10: 266.

Microtendipes lamprogaster Kieffer, 1923, Ann. Soc. sci. Brux. 42 (I) : 387; Freeman, 1955, S. Afr. Animal Life. Uppsala, $2: 378$.

Wings unmarked, thorax with reddish stripes, knees of anterior legs dark, abdomen with basal dark markings on segments 2-5. It is most like satchelli and umbrosus, but can be distinguished from the former as shown in the key and from the latter by the plain wings and black marked abdomen.

Male. Wing length $3 \cdot 25-3.5 \mathrm{~mm}$.

Head greenish, palpi brown, pedicel reddish, A.R. about $2 \cdot 4$, frontal tubercles absent. Thorax yellowish green, stripes reddish brown and separate, postnotum and sternopleuron dark brown. Legs yellowish green, knees and apices of tibiae darkened, anterior femur with about one-sixth darkened, tibia with basal quarter dark, femur lacking basally directed patch of bristles, L.R. barely I, anterior tarsus not bearded. Wings quite unmarked, venation normal, halteres pale. Abdomen greenish, segment I with obscure brown markings, 2-4 with a dark basal ring occupying about one-third of segment, usually extended in the mid-line almost to the posterior border, segment 5 similar but less well marked, 6-9 more completely dark. Hypopygium (Text-fig. 7, a) not differing from other species of the genus.

Female similar to male but abdominal markings less well developed; antennae more or less 7 -segmented, segments 2 and 3 being only indistinctly separated.

I have been able to borrow cotypes from the South African Museum (type locality Cape Town).

Distribution. Known only from CaPe Province. Berg River, French Hoek,

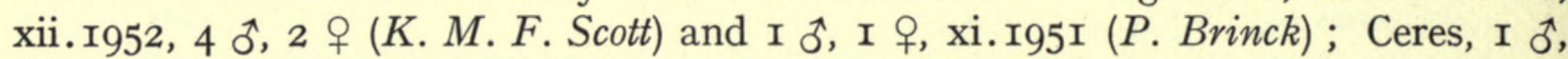
xi. 1920 (R. E. Turner).

\section{Microtendipes satchelli Freeman}

Microtendipes satchelli Freeman, 1955, S. Afr. Animal Life. Uppsala, $2: 379$.

Easily distinguished from other African species by the colour, closest to lamprogaster but separated by the wider dark apex of the anterior femur, darker thorax and pale unmarked basal abdominal segments ; male with patch of basally directed bristles on anterior femur. This and lamprogaster are the only two African species known to me with plain wings.

Male. Wing length $3.5 \mathrm{~mm}$.

Head reddish yellow or brown, face paler, palpi darker, antennae reddish, pedicel may be dark, plumes whitish at the apex, A.R. $2 \cdot 5-3 \cdot 0$. Thorax with mesonotal stripes brown or black and more or less fused across, shoulders may be greenish, prescutellar area sometimes paler and pruinose; scutellum, postnotum and pleura dark brown; specimens from Elisabethville have the thorax almost entirely black. Legs yellowish green except for apical third or half of anterior femur and basal third and apex of anterior tibia which are blackish, other knees with traces of darkening; L.R. about $\mathrm{I} \cdot 2$, anterior femur with a subapical patch of setae directed 
towards the base. Wings quite unmarked, halteres yellow. Abdomen with segments I-5 yellowish green and unmarked, remainder dark; hypopygium similar to lamprogaster.

Female not unlike male in colour and pattern but thoracic stripes separate, cuticle between yellowish brown; abdomen less obviously pale on basal 5 segments, antennae more or less 7 -segmented.
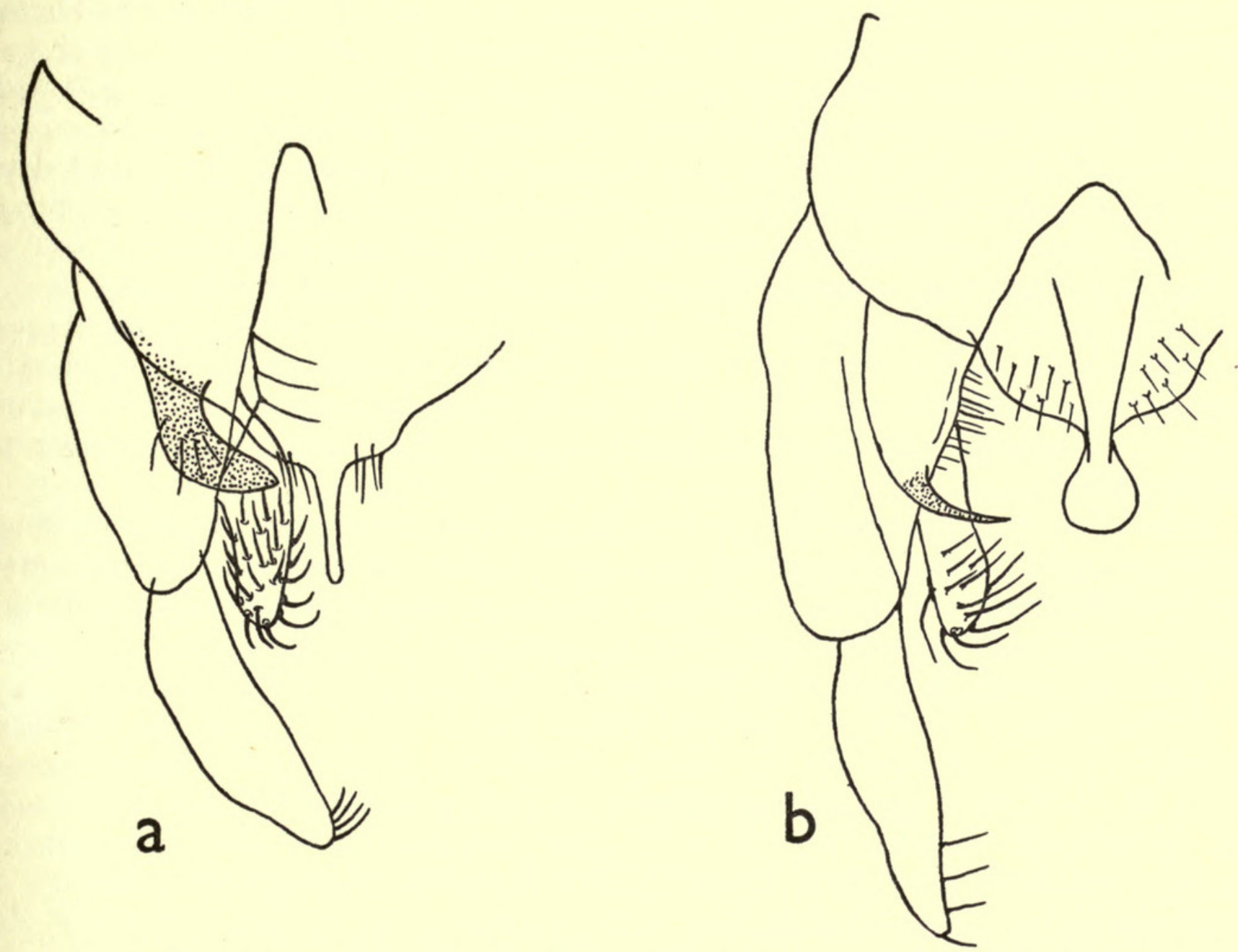

Fig. 7. Male hypopygia of Microtendipes and Kribiocosmus. (a) M. lamprogaster; (b) K. ornatipes.

Holotype male in the British Museum.

Distribution. CAPE Province : holotype male and I ô paratype, Transkei, Mt. Currie, Kokstad, iii. I953 (G. H. Satchell). Basutoland : 2 ऽ, Maseru, Lancer's Gap, iii.r95I (P. Brinck). Belgian Congo: I2 ô, 5 ㅇ, Elisabethville, iii. I939 (H. J. Brédo).

\section{Microtendipes umbrosus Freeman}

Microtendipes umbrosus Freeman, 1955, Explor. Parc Nat. Albert, Miss. de Witte, 83 : 32, Freeman, 1955, S. Afr. Animal Life. Uppsala, $2: 378$.

A medium-sized yellowish brown species with darker markings on thorax, especially on lateral stripes; female antennae more or less 7 -segmented; legs with knees 
dark and a dark ring near the middle of the anterior femur; wings with a median transverse dark band or shade ; abdomen pale on segments I-5 or pale with narrow dark rings. Distinguished from species with similar body markings such as satchelli by the wing markings and the anterior femoral ring.

Male. Wing length $2 \cdot 5-3 \cdot 75 \mathrm{~mm}$.

Head yellowish brown, mouthparts dark; antennal pedicel reddish, plumes paler towards apex, A.R. 2-2*3. Thorax with pale shoulders which may be almost whitish; stripes brown, lateral ones usually darker brown, stripes more or less fused across thorax, postnotum and sternopleuron dark brown. Legs yellowish white, all knees and apices of tibiae dark ; anterior knees more broadly darkened so that basal third or more of tibia may be black; anterior femur with broad dark ring distal to the middle, other femora with traces of a similar ring; anterior tarsal segments dark at extreme apices ; anterior femur with patch of setae directed basally, L.R. I·2. Wings with a central dark shade or band (Pl. 2, fig. $f$ of female), hardly extending basal to posterior fork but sometimes extending in cell $\mathrm{R}_{4+5}$ towards apex so that a good deal of apical half appears shaded; halteres pale. Abdomen with segments I-5 unmarked yellowish white in most specimens, occasionally with narrow dark rings at apices of segments, apical segments dark, hypopygium similar to lamprogaster.

Female essentially similar to male but darker in colour and wing and leg markings more extensive ; ring on posterior femora more distinct, that of anterior femur may be partially joined to apical darkening; abdomen not always distinctly paler on basal 5 segments ; antennae more or less 7 -segmented.

Holotype female in the British Museum.

Distribution. Kenya: holotype female and I $\hat{0}$, I + paratype, Nyanza, Lumbwa Distr., xii.IgII (C. M. Dotts). Sudan: I $\hat{0}, 4$ 우 Jebel Marra, 6,0008,000 ft., v-vi.r932 ( $M$. Steele). Nigeria: 8 ふో, 4 ㅇ, Kankiya, xii.r956-i.I957 (B. McMillan). Belgian Congo: 7 , Parc National Albert, Riv. Bishakishaki, iv.I934 (de Witte) ; 4 oิ, 3 o, Elisabethville, xi.I938-iii.I939 (H. J. Brédo) ; I ô, Lwiro-Bukavu, v.I957 (J.Hamon). S. Rhodesia: I ô, Mt. Chironda (C. F. M. Swynnerton); I 옹 Salisbury, ii-iii.I956 (E. T. M. Reid). TransvaAl: I 우 Waterval, Lydenburg, iv. I955 (A. D. Harrison). S. W. Africa : I6 đ̊, 4 o, Kaokoveld, Anabib (P. Brinck).

\section{Microtendipes albus Goetghebuer}

Polypedilum album Goetghebuer, 1936, Rev. Zool. Bot. Afv. $28: 482$.

Microtendipes rutshuruensis Freeman, 1955, Explor. Parc Nat. Albert, Miss. de Witt, 83 : 34 ; Freeman, 1955, S. Afr. Animal Life. Uppsala, 2: 378 (syn. Nov.).

A pale species with distinctively patterned wings, the cloud at the apex distinguishing it from other African species except filitarsus and lentiginosus ; it is separated from the former by the presence of dark markings at the apices of tibiae and tarsal segments and from the latter by the quite different wing pattern. I have examined Goetghebuer's type and find it to be the same species as rutshuruensis. He omitted the apical wing cloud from his figure although it is quite distinct on the specimen 
and his placing of the species in Polypedilum is wrong as it shows all the generic characters of Microtendipes.

Male. Wing length $2 \cdot 5-3 \cdot 0 \mathrm{~mm}$.

Head, mouthparts and antennae reddish yellow, plumes whitish, A.R. about 2. Thorax with whitish yellow pruinose background; stripes, especially lateral ones, postnotum and sternopleuron brown or dark brown. Legs whitish, anterior knees broadly black, middle and posterior knees less strongly marked, more brownish or with a ring above and below; anterior femur with a central dark band which may be greatly reduced; apices of all tibiae dark, apices of all tarsal segments broadly dark; basitarsus without the central dark ring seen in the female but examination of more material may show that it usually is present; L.R. I.3, anterior femur with basally-directed patch of setae poorly developed. Wings similarly patterned to the female (Pl. 2, fig. g) ; apex clouded and with four more clouds as shown; halteres pale. Abdomen yellowish white, incisures may be narrowly darkened, hypopygium as in lamprogaster.

Female. Wing length $2-3.5 \mathrm{~mm}$.

Very similar to male in pattern, thorax may be considerably paler, legs have an additional dark band in centre of basitarsus ; antennae with 6 segments.

Holotype male of album in Musée Royal du Congo Belge, Tervuren, of rutshuruensis in the British Museum (both from BELGIAN Congo : Rutshuru).

Distribution. Belgian Congo: type specimens from Rutshuru: i 우 Elisabethville, ii. $\operatorname{I939}(H . J$. Brédo) ; 2 오, Lwiro-Bukavu, v.I957 (J. Hamon). TANGANYIKA: 2 o, Njombe, viii-ix. I95I ( $W$. Peters). NATAL: I oै, Weenen, viii. I924 (H. P. Thomasset) ; 4 ㅇ, Royal Natal National Park, iv. I95I (P. Brinck).

\section{Microtendipes lentiginosus Freeman}

Microtendipes lentiginosus Freeman, 1955, Explor. Parc Nat. Upemba, 35 : 100.

In general structure and in the colour of body and legs this species is extremely similar to albus, differing only in the presence of a central dark band on the femora of all legs and in the absence of a central basitarsal ring; its size is smaller (wing length $2 \mathrm{~mm}$. for all specimens). The main point of difference between it and all other species is the peculiar wing pattern (Pl. 2, figs. $i, j$ ) which is composed of numerous small rounded dark spots with blotches at the cross-vein, posterior fork and apex. The detailed number and arrangement of the spots differ not only from specimen to specimen but also on both sides of the same specimen; fig. $i$ of the holotype illustrates a paler specimen, the paratype in fig. $j$ is a commoner pattern but darker; more heavily patterned ones do occur.

Holotype female is in the collection of the Institut des Parcs nationaux du Congo Belge.

Distribution. Kenya: i ㅇ paratype, Kavirondo, ix. Igir (C. N. Woodhouse). Belgian Congo: holotype female, Parc national de l'Upemba, x.I947 (de Witte); 2 ô, 2 우, Elisabethville, xii. I938 and iv. I939 (H. J. Brédo). NATAL : I ㅇ, Bergville, xii. 1954 ( $W . D$. Oliff). 


\section{Microtendipes taitae Kieffer}

Chironomus taitae Kieffer, I913, Voy. All. Jean. Afr. Or. Ins. Dipt. 1 : 15.

Polypedilum (?) annulaticrus Kieffer, 1922, Ann. Soc. ent. France, 91 : 3 I (syn. nov.).

Thorax with brown stripes, abdomen of male yellow with dark incisures, legs dark at the knees and apices of tibiae and with a central dark band on the anterior femur ; easily distinguished from all other African species by the wing pattern which is formed of seven spots, two being in the posterior fork cell.

I have examined the series of cotypes of taitae and can confirm the identity of the species but the type of anmulaticrus is lost. It cannot belong to Polypedilum because the eighth segment of the male abdomen is not contracted basally; the presence of two spots in the posterior fork cell makes it reasonably certain that it is a redescription of taitae.

Male. Wing length $3 \cdot 25-3 \cdot 75 \mathrm{~mm}$.

Head and pedicel yellowish brown, mouthparts blackish, A.R. 2.5. Thorax greenish brown; stripes, postnotum and sternopleuron reddish or dark brown, shoulders and prescutellar area pruinose. Legs greenish or yellowish brown, broadly darkened at the knees, anterior femur with a broad dark ring beyond the middle, other femora sometimes with this ring or sometimes with the basal half darkened; tibiae and tarsal segments dark at apices; front femur with poorly developed patch of setae directed basally, L.R. I·3. Wings (Pl. 2, fig. $h$ of female) with well-developed pattern of seven spots, outer three more or less in a line across wing, posterior fork cell containing two; exact extent of each spot variable to a limited extent, the larger one in cell $\mathrm{R}_{4+5}$ sometimes appearing double, the one behind it in cell $\mathrm{M}_{1+2}$ occasionally absent; halteres pale. Abdomen with segments I-5 yellowish white, incisures narrowly dark, apical segments more or less darkened; hypopygium similar to lamprogaster.

Female similar to male in colour and pattern, antennae with 6 segments.

Cotypes of taitae are in Muséum National d'Histoire Naturelle, Paris (type locality KenYa : Taita) ; type of annulaticrus lost (type locality French CAMERoons: Kribi).

Distribution. Gold Coast: i o , Nangodi, x.I954 (G. Crisp). Kenya : I $\widehat{0}$, I ㅇ, Nairobi, v. IgII (T. J. Anderson). Belgian Congo: I $\hat{0}$, Kalunga, x.I925 (J. Schwetz) ; 7 ô, 9 ㅇ, Elisabethville, ii-iii.I939 (H. J. Brédo); I ㅇ, Elisabethville, ii.I934 (C. Seydl). N. Rhodesia : I o, Chilanga, ix.I9I3 (R. C. Wood $)$. S. Rhodesia: I ô, Chirinda Forest, xi.r93o (A. Cuthbertson); I +, Salisbury, ii-iii. I956 (E. T. M. Reid). NATAL : I + Kloof, ix.I926 (R. E. Turner); 2 ô, Rosetta, ix.I953 (A. D. Harrison).

\section{Microtendipes bifasciatus Kieffer}

Kribiomimus bifasciatus Kieffer, I921, Ann. Soc. ent. France, 90 : 5 I.

Kribiocharis annulaticrus Kieffer, 1922, ibid. $91: 5$ (sYN. Nov.).

Kribiocallis fasciatipennis Kieffer, I922, ibid. 91 : I6 (syn. Nov.).

Hulstaevtiella caloptera Goetghebuer, 1936, Rev. Zool. Bot. Afr. $28: 45^{6}$ (syn. Nov.).

Polypedilum bicinctum Goetghebuer, 1936, ibid. $28: 483$ (syn. Nov.). 
Wings heavily marked with two dark bands which are connected to a greater or lesser extent, apex clear and there are clear spots in fork and anal cells ; legs dark at knees, at apices of tibiae and tarsal segments and with a central dark femoral ring; thorax with white pruinosity, abdomen of male pale, each segment with a dark ring basally. The wing markings, although variable in intensity, make this species easily recognizable. Although I have not seen the types, Kieffer's three species agree very well with my specimens. I have seen both of Goetghebuer's types and find that bicinctum was described from a pale male and caloptera from a dark female.

Male. Wing length $2 \cdot 5-3 \cdot 0 \mathrm{~mm}$.

Head yellowish or brown, mouthparts brown, pedicel yellow, plumes white, at least apically, A.R. about 3. Thorax yellowish brown with white pruinosity on shoulders, between stripes and in prescutellar area. Legs yellowish white, knees broadly darkened, apices of tibiae and of tarsal segments dark, femora with a broad brown ring just beyond the middle; anterior femora without the basally directed hair patch, L.R. I.5. Wings heavily patterned as shown in Pl. 2, fig. $k$ of female ; markings can be considered as formed of two dark bands one at level of apex of $R_{1}$, the other bounded basally by cross-vein $\mathrm{r}-\mathrm{m}$; the two bands are more or less distinctly connected centrally leaving an oval clear area in cell $\mathrm{R}_{4+5}$; the outer band tends to creep along vein $\mathrm{M}_{1+2}$ and there is another clear spot between the bands in the fork cell ; basal band expands in anal cell which contains another dark basal spot, the area between the two is clear and more or less circular. Abdomen yellowish, each segment narrowly darkened basally; hypopygium similar to lamprogaster.

Female resembles male but wing pattern more intense; grey area connecting the two bands may cover cell $R_{4+5}$ as well as $\mathrm{M}_{1+2}$ so that there appears to be only one broad and more or less continuous band relieved only by the spot in the fork cell ; these two extremes of intensity are shown in Pl. 2, figs. $k, l$; antennae probably 6 -segmented.

Type series of all three of Kieffer's species lost, type locality of all, FrENCH Cameroons: Kribi, bifasciatus was based on males, the other two on females. The types of Goetghebuer's species are in Musée Royal du Congo Belge, Tervuren.

Distribution. Sierra Leone: I ô, Njala, viii.r93o (E. Hargreaves). TanGanyika: 2 옹 Njombe, ii. I952 (W. Peters). Belgian Congo : I $\hat{0}, 3$ 우, Stanleyville (Mouchet) ; I ㅇ, Eala, v.I935 (J. Ghesquière); I ㅇ, Elisabethville, xii. I938 (H. J. Brédo); holotype male of bicinctum, Stanleyville, holotype female of caloptera, Flandria.

\section{? Microtendipes flavipes Kieffer}

Kribiomimus flavipes Kieffer, I92I, Ann. Soc. ent. France, $90: 52$.

I have seen no specimens which agree with the description of this species. It probably belongs to Microtendipes because it is said by Kieffer to resemble bifasciatus of which it may be a teneral specimen. The main difference lies in the absence of dark markings on the legs which are completely yellow. The wing markings resemble those of bifasciatus with the two transverse bands joined by a grey band in cell $\mathrm{M}_{1+2}$, hypopygium as in bifasciatus. Length 4-5 $\mathrm{mm}$. 
Known only from the holotype male which is lost, type locality FrencH Cameroons : Kribi.

\section{Microtendipes luteipes Kieffer}

Kribiocharis luteipes Kieffer, 1922, Ann. Soc. ent. France, $91: 3$.

I have seen no specimens agreeing with the original description, but from the produced thorax, the figure of the male hypopygium and the square shape of the eighth segment of the male abdomen it probably belongs to this genus. It differs from all other species except flavipes by the unmarked pale legs; it may be separated from flavipes by the presence of a single transverse dark band on the wing. The following description is taken from the original.

Length of male $3.8-4 \mathrm{~mm}$., of female $3-3.5 \mathrm{~mm}$.

Clear yellow. Male antennae brownish, A.R. I·5, female antennae with 6 segments. Thorax prolonged above head, concolorous in female, but stripes, postnotum and sternopleuron yellow in male; halteres white. Wings with fork cell and cell between the stem of the fork and the anal vein grey to the posterior border except for two clear spots on the border, the distal in the fork cell against $\mathrm{Cu}$, the other at the extremity of the anal cell; the other grey spots are : two confluent, together forming a transverse band going from $\mathrm{R}_{4+5}$ to $\mathrm{M}_{1+2}$ opposite the extremity of $\mathrm{Cu}$ and a grey tract on the proximal third of $\mathrm{M}_{1+2}$. Legs entirely yellow, anterior femur equal to tibia, tarsi not bearded, L.R. more than I, pulvilli short; tibial scale rounded and transverse. Male abdomen yellowish white, incisures darker, VIIIth tergite square ; hypopygium, from the figure, very similar to lamprogaster. One female is mentioned with the whole of cell $R_{4+5}$ grey, though paler in colour than the spots.

Known only from the type series now lost, type locality French CAMERoons : Kribi.

\section{Genus KRIBIOCOSMUS Kieffer}

Kribiocosmus Kieffer, I921, Ann. Soc. sci. Brux. 40 (I) : 271; Kieffer, 1921, Ann. Soc. ent. France, $90: 48$.

Eyes rather widely separated above, narrow portion hardly longer than wide, frontal tubercles absent, palpi well developed and thick, clothed with more bristly hairs than is usual, A.R. of the only known species about $0 \cdot 6$, female antennae not known. Prothorax reaching nearly to front of mesonotum, but not visible from above, dorso-central and acrostichal bristles both well developed. Anterior tibial scale triangular and with a narrow slightly curved spur at the apex as long as the scale itself ; combs of other tibiae fused, each pair with a single short spur ; pulvilli not visible with a binocular microscope. Wings clouded, $\mathrm{R}_{2+3}$ ending midway between $R_{1}$ and $R_{4+5}$, posterior fork below cross-vein, squama fringed. Male abdomen with eighth segment not constricted at the base ; two hypopygial appendages present, coxite and style narrow.

This genus was described by Kieffer to include the only known species $K$. ornatipes Kieffer which is automatically the type species of the genus. In general appearance 
and in the structure of the front tibial spur it resembles Lauterborniella but the combs on the other tibiae are more like those of Stictochironomus. These characters combined with the virtual absence of pulvilli are sufficient to separate it from all other described genera.

\section{Kribiocosmus ornatipes Kieffer}

Kribiocosmus ornatipes Kieffer, I92I, Ann. Soc. ent. France, $90: 48$.

Mesonotum with strongly developed pruinosity along the hair lines, legs dark but tarsi banded with yellow, wings distinctively clouded, anal point of male broadened at tip.

Male. Wing length $2 \mathrm{~mm}$.

Head yellowish-brown, palpi darker, antennae with reddish pedicel, flagellum with segments I-4 whitish, plumes rather sparse, A.R. only o.6. Thorax brown and with a pair of broad and conspicuous silvery pruinose stripes along lines of dorso-central bristles from anterior to posterior margins of mesonotum; line of acrostichal bristles less obviously pruinose. Legs brown with yellow markings; coxae, bases of femora, knees of posterior four legs pale; anterior basitarsus pale with dark apex, second and third segments narrowly pale basally, 4 and 5 completely dark; L.R. I.75, tarsal beard absent ; basitarsus of other legs with a broad median pale band, segments 2 and 3 broadly pale basally, remainder dark. Wings ( $\mathrm{Pl}$. 2, fig. $m$ ) clouded, cell $\mathrm{R}_{4+5}$ with clouds basally, beyond the centre and at the apex, fork cell with a central cloud, anal cell with two; halteres yellow. Abdomen dark brown. Hypopygium (Text-fig. $7, b$ ) quite characteristic ; anal point downturned and broadened at the apex, appendage I narrow and sharply pointed, appearing as a continuation of a curved ridge on the coxite, appendage 2 short and without long apical hair, styles narrow and contracted apically.

Female. So far as can be seen from the only, rather damaged, specimen available, similar to male; antennae broken.

I have not seen the holotype male which is probably lost (type locality FrENCH Cameroons : Kribi) but it can easily be identified from Kieffer's description and figure.

Distribution. Gold Coast: I $\hat{\jmath}$, Koforidua, vii. Igig (F. H. Storey) ; 2 ô, I 9 , Bolgatanga, xi. I954 (G. Crisp). French West Africa, Soudan : I ơ, Bamako, xi.I953 (J. Hamon). Belgian Congo: I ô, Stanleyville, viii. I928 (A. Collart).

\section{Genus LAUTERBORNIELLA Bause}

Lauterborniella Bause, I9I4, Arch. Hydrobiol. Suppl. 2: I20; Kieffer, I921, Ann. Soc. ent. France, $90: 28$; Townes, 1945, Amer. midl. Nat. 34 : 19.

Zavreliella Kieffer, 1920, Bull. Soc. ent. France, $1919: 334$.

Kribiodorum Kieffer, I92I, Ann. Soc. sci. Brux. 40 (I):270; Kieffer, I921, Ann. Soc. ent. France, $90: 46$.

Chironomus subg. Lauterborniella Edwards, I929, Trans. ent. Soc. Lond. $77: 404$.

Male antenna with I3 or I4 segments, the last two often indistinctly separated, female with 6-7 segments; frontal tubercles absent. Pronotum reduced and not 
visible from above. Anterior tibia usually with a short sharp spur or triangular pointed scale ; combs of posterior tibiae separate, the smaller with a spur which may be long and strong; pulvilli well developed. Wings with $\mathrm{R}_{2+3}$ ending beyond tip of $R_{1}$, squama bare. Eighth segment of male abdomen not contracted basally, usually two hypopygial appendages, but in one species $2 a$ is present as well.

The four African species which I am placing in this genus are probably not all very closely allied to one another; pulchra is closely allied to a North American species and fuscoguttata may be a synonym of a European species. These two and longiventris would belong to the subgenus Zavreliella, but following Townes (I945) I prefer not to recognize this as a distinct subgenus.

\section{Key to African Species of Lauterborniella}

I. Legs completely yellow, without dark markings; wings with two grey transverse bands (Pl. 2, fig. $q$ )

Legs with dark markings, especially at apices of anterior femora .

2. Wing pattern as in Pl. 2, fig. $n$; fork cell with three dark spots

Wing pattern not so obviously in for of

3. Wing with clear areas forming two bands (Pl. 2, fig. o)

Clear areas not like this (P1. 2, fig. $p$ ) - pallidipes Kieffer fuscoguttata Kieffer less clear

pulchra Kieffer longiventris Goetghebuer

\section{Lauterborniella fuscoguttata Kieffer}

Polypedilum fuscoguttatum Kieffer, 1922, Ann. Soc. ent. France, 91 : 37.

Blackish or dark brown, pruinose, wings heavily marked with eleven or twelve spots, fork cell with three spots. Legs pale, tarsi banded, abdomen with basal tuberosities on each segment dorsally, especially obvious in the male.

This species is easily recognized by the wing pattern, banded tarsi and abdominal tuberosities. It is doubtfully distinct from the parthenogenetic European species L. marmorata van der Wulp, but I am maintaining the separation until such time as males are known of the latter or until more is known of their biology. The North American species $L$. varipennis Coquillett may well prove to be another synonym, judging from the description given by Townes (I945). He distinguishes Coquillett's species from the European one by the absence in the latter of the abdominal tuberosities, by its heavier wing markings and constant single spurred condition of the posterior tibia. In actual fact the tuberosities are present, but as they are not strongly developed in females, have not been mentioned in the literature.

Male. Wing length $\mathrm{I} \cdot 75 \mathrm{~mm}$.

Head, mouthparts and pedicel of antennae dark brown or blackish, A.R. about I.2. Thorax dark brown or blackish, marbled with pruinosity. Legs yellowish with darker markings, anterior femur clubbed on apical half which is black, other femora dark on basal halves; anterior tibia black, knee pale, other tibiae blackish at tips; all tarsal segments dark at apices. Anterior tibia about half as long as femur, L.R. 2.5, tibial spur well developed and straight; small comb of posterior tibia projecting beyond other comb and twisted to give a characteristic appearance. Wings (Pl. 2, fig. $n$ of female) with heavy pattern, the three spots in the fork cell being especially characteristic; squama bare, halteres white. Abdomen black, 
hypopygium paler; each segment with an oval, longitudinal, ridge or tuberosity in its basal half and a silvery pruinose patch on its apical half, each ridge bears a tuft of hair. Hypopygium (Text-fig. 8, a) very similar to the North American species $L$. varipennis.

Female similar to male but abdominal tuberosities less strongly developed, antennae with 6 segments.

Cotype females probably lost (type locality Sudan: Shambe).

Distribution. Sudan : 8 o, Melut, Tonga and Adok, xi.I953 (E. T. M. Reid) ;

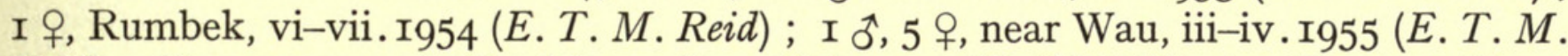

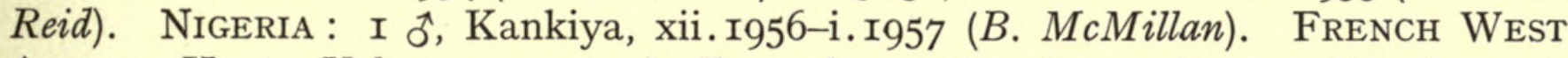
AfricA, Haute Volta: 3 ઈิ, I + , Tangrela nr. Banfora, xii.I956 (J. Hamon). S. Rhodesia : I + , Salisbury, iv. I956 (E. T. M. Reid).
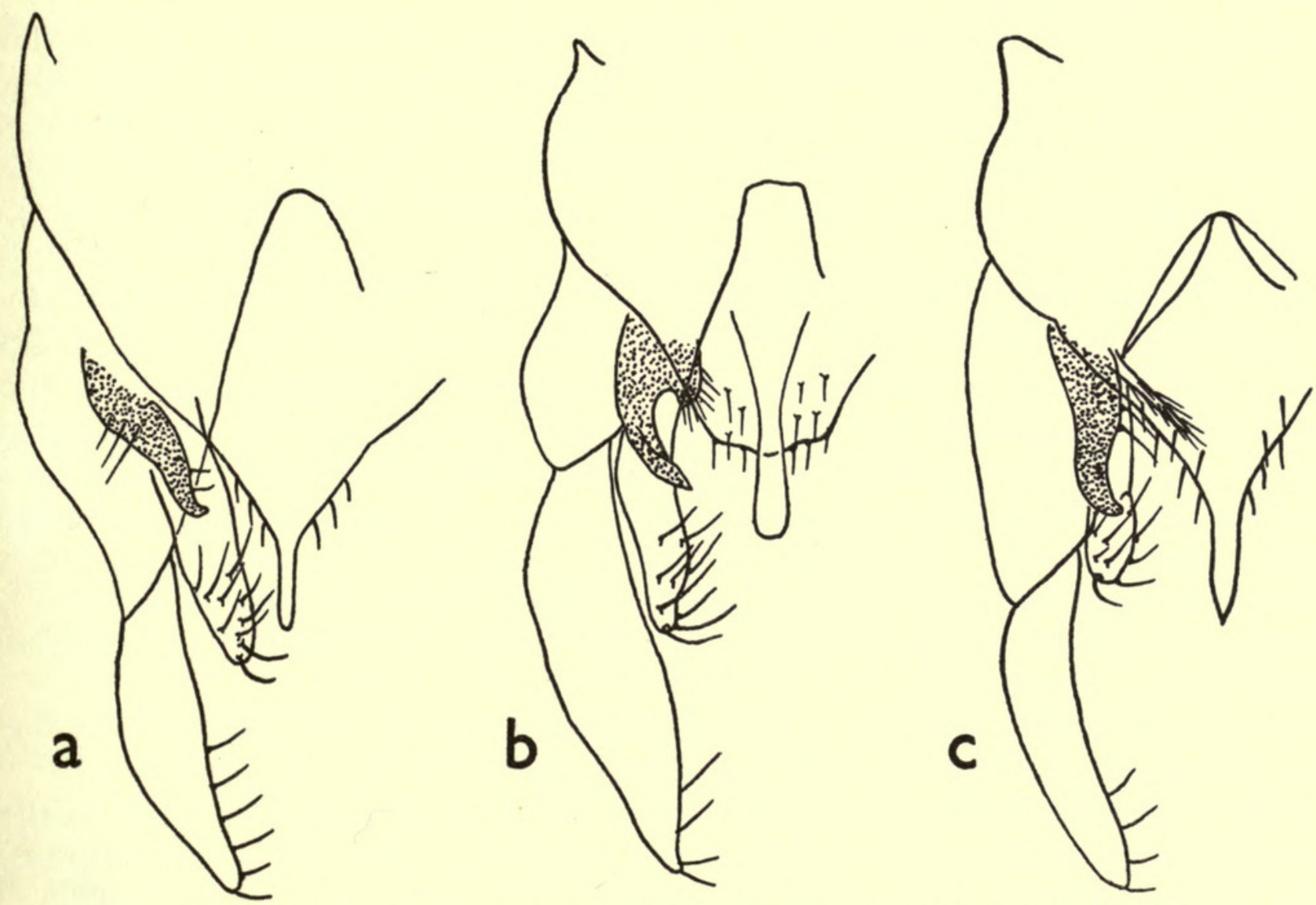

FIG. 8. Male hypopygia of Lauterborniella. (a) L. fuscoguttata ;

(b) L. pulchra; (c) L. pallidipes.

\section{Lauterborniella pulchra Kieffer}

Kribiodorum pulchrum Kieffer, I921, Ann. Soc. ent. France, $90: 46$.

Paratendipes violaceus Goetghebuer, 1936, Rev. Zool. Bot. Afr. $28: 45^{8}$ (syn. Nov.).

Thorax greenish or yellowish, legs variably banded with black, anterior femur more or less swollen at apex which is always black, anterior tibia always pure white on basal half or more; wings brown or blackish with clear areas at the apex and others forming a median band. The leg and wing markings are sufficient to dis- 
tinguish it from all other African species known to me. It shows a strong resemblance in appearance, structure and pattern to the North American species L. perpulcher Mitchell but it may be distinguished by the wings being dark right to the base and by the shape and arrangement of the clear areas in the fork cell and anal cell.

It is easily recognized from Kieffer's description and I have been able to examine Goetghebuer's type and can confirm the synonymy. It is not clear why Goetghebuer placed it in Paratendipes, but it may be because the number of tibial spurs is difficult to determine from his specimen; he has also confused the legs in his figure, because on the holotype the middle tarsi are present and the posterior ones broken, whereas in his drawing tarsi are present on hind legs only. The dark colour of his type is probably caused by scorching which often makes material taken at light unnaturally dark.

Male. Wing length $\mathrm{I} \cdot 75^{-2} \cdot 0 \mathrm{~mm}$.

Head greenish or yellowish, pedicel yellowish brown, A.R. about I·o, palpi yellow. Thorax greenish or yellowish with reddish yellow stripes, postnotum dark, pleura with a broad horizontal dark stripe which continues the colour of the abdomen. Legs yellow with variable dark and white markings ; anterior femur slightly swollen apically, apical third always black, all femora may have a broad dark ring near the middle, posterior femora may be dark at apices as well ; anterior tibia strikingly white on basal half or two-thirds, apical half or third black, other tibiae either completely yellow or else white basally and with an indefinite broad dark median band; anterior tarsi of males all broken but in females anterior basitarsus pale on basal half, other segments dark, tarsal segments of other legs broadly dark at apices ; L.R. of females about 2, anterior tibial spur long and curved, scale reduced, spur often broken. Wings (Pl. 2, fig. $o$ of female) brown or blackish with pale areas as shown, though these are variable in extent; squama bare. Halteres green or yellow. Abdomen brown, each segment indefinitely paler in basal half or more, hypopygium white. Hypopygium (Text-fig. 8, b) very similar to that of $L$. perpulcher Mitchell (North America).

Female very similar to male in colour, general structure and pattern; antennae with 7 segments, $\mathrm{I}-6$ may be white, 7 is always dark.

I have not seen the type series of pulchra which is probably lost (type locality French Cameroons : Kribi); holotype of of violaceus is in the Musée Royal du Congo Belge, Tervuren (Belgian Congo: Rutshuru).

Distribution. Gold Coast : I +, Kete Krachi, x. I898 (Graf Zech). Sudan : 6 o, 6 ㅇ, Khartoum, x.I95I (D. J. Lewis); I ㅇ, Amadi, vi-vii.r954 (E. T. M. Reid). Natal: I , Howick, iv.r953 (G. H. Satchell). The type localities are additional.

\section{Lauterborniella longiventris Goetghebuer}

Kribiomimus longiventris Goetghebuer, 1936, Rev. Zool. Bot. Afr. $28: 454$.

Thorax greenish with reddish mesonotal stripes and dark pleural stripe; legs golden, apices of segments broadly blackened, anterior tibiae with spur; wings heavily patterned, apex clear; abdomen blackish, each segment pruinose at extreme 
apex. Only the holotype is known; the general appearance, bare squama, slightly clubbed anterior femur and spurred anterior tibia place it in Lauterborniella near pulchra. Through the kindness of Dr. P. L. G. Benoit I have been able to include a photograph of the wing.

Male. Wing length $2.75 \mathrm{~mm}$., body length $5 \mathrm{~mm}$. (not $7 \mathrm{~mm}$. as stated by Goetghebuer).

Head brown, A.R. I.75 (not 2.5 as stated by Goetghebuer). Thorax greenish, stripes and sternopleuron reddish brown, horizontal pleural stripe and postnotum black. Legs golden yellow, anterior femur slightly clubbed, apical quarter of all femora and third of tibiae black, segments $\mathrm{I}-4$ of anterior tarsus with apical thirds black, on other legs black at tips; in addition traces of black bands present at middle of femora and at bases of tibiae. Anterior tibia appears to have well-formed long spur at apex of small oval scale, spur of other tibiae short, L.R. 2*0. Wings mainly dark, but apex and a large spot in fork cell clear, other spots as shown in Pl. 2, fig. $p$; squama bare, halteres yellow. Abdomen blackish with golden hairs and traces of paler colouring on segments 2 and 5 ; each segment with narrow pruinose band at apex. Hypopygium broken but anal point long and appendage I hook-like as seen in dried specimen.

Female not known.

I have seen the holotype male in Musée Royal du Congo Belge, Tervuren, type locality, Belgian Congo: Kasai, Ilebo. No other specimens are known to me.

\section{Lauterborniella pallidipes Kieffer}

Kribiomimus pallidipes Kieffer, I921, Ann. Soc. ent. France, 90 : 52.

Thorax yellowish or reddish with a dark lateral stripe on pleuron, abdomen blackish ; legs yellow without dark markings, tibial scale oval, spur absent, posterior tibial spur long and curved; wings with two transverse grey bands; male hypopygium with appendage $2 a$ present. It can easily be distinguished from the other African species by the pale legs and by the wing pattern ; in some ways, for instance in the absence of a long anterior tibial spur and in the presence of appendage $2 a$, it is not very typical of the genus, but the bare squama, long posterior tibial spur and presence of pulvilli, cause it to fall here better than into any other genus.

Male. Wing length $\mathrm{I} \cdot 5-\mathrm{I} \cdot 75 \mathrm{~mm}$.

Head yellowish brown, palpi yellow, pedicel brownish, A.R. about $\mathrm{I} \cdot 2$. Thorax yellowish, mesonotal stripes reddish, postnotum and a lateral horizontal pleural stripe dark brown. Legs yellow and without markings; anterior tibial scale oval and without spur or spine, although a very short dark point can sometimes be seen at the apex, L.R. about $2 \cdot 2$, pulvilli present, tarsal beard absent; posterior tibial combs not fused, with one long spur, curved at the apex. Wings (Pl. 2, fig. $q$ of female) with two grey transverse bands, one at level of cross-vein and the other at level of apex of $\mathrm{R}_{2+3}$; squama bare. Abdomen blackish, hypopygium not paler ; hypopygium (Text-fig. $8 c$ ) with stout anal point and three appendages ; appendage $2 a$ straight and hairy, styles slightly curved, coxites long. 
Female similar to male, antennae with 6 segments.

The type series is probably lost (French Cameroons: Kribi).

Distribution. Sierra Leone: i ô, i ㅇ, Pepel, i.r956 (D. J. Lewis). Gold Coast : I o, Nangodi, x.I954 (G. Crisp). Nigeria : I ô, Katsina, x.I956 (B.

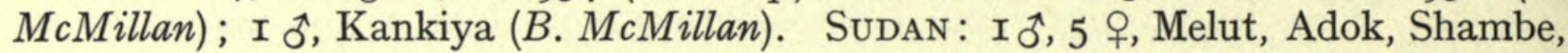
xi.I953 (E. T. M. Reid) ; 4 ô, I ㅇ, nr. Wau, iii.I955 (E. T. M. Reid). Belgian Congo : I ô, 5 +, Musosa, x. I939 and 3 ô, I3 ㅇ, Elisabethville, iii. I939 (H. J. Brédo). S. Rhodesia : i ㅇ, Salisbury, iv.I956 (E. T. M. Reid).

\section{Genus KRIBIODOSIS Kieffer}

Kribiodosis Kieffer, 1921, Ann. Soc. sci.Brux. 40 (I) : 270; Kieffer, 1921, Ann. Soc. ent. France, $90: 40$.

Male antennae with I3 or I4 segments, segmentation often indistinct, female antennae with 5 only, the last one being swollen at the base and formed by the fusion of 2 segments ; frontal tubercles absent. Pronotum reduced and not visible from above. Legs unusually long and thin, anterior femora and tibiae slightly clubbed at apices; anterior tibia with a sharp spur arising from a reduced and transverse scale, combs of posterior tibiae separate and the smaller with a very long thin curved spur ; pulvilli scarcely distinguishable. Wings narrow and cuneiform, squama bare, $\mathrm{R}_{2+3}$ separated from $\mathrm{R}_{1}$ at the apex, $\mathrm{Cu}_{1}$ short, only about half as long as $\mathrm{M}_{3+4}$ (Text-fig. 9, a). Eighth segment of male abdomen contracted basally, hypopygium with two appendages.

This genus is very close to Lauterborniella in most of its characters but I prefer to keep it distinct until more species are known because its appearance is different with its long thin legs and narrow wings and also because the eighth segment of the male is basally contracted, the pulvilli are reduced and the female antenna has only 5 segments.

Kieffer described five African species all from the same locality, but I can see no reason for maintaining them as distinct from each other. No other species are known. Type species of the genus $K$. clavigera Kieffer by original citation (as fasciata Kieffer).

\section{Kribiodosis clavigera Kieffer}

Kribiodosis clavigera Kieffer, I921, Ann. Soc. ent. France, $90: 4 \mathrm{I}$.

Kribiodosis fuscithorax Kieffer, I92I, ibid. $90: 42$ (sYN. Nov.).

Kribiodosis distans Kieffer, I92I, ibid. $90: 42$ (SYN. NOv.).

Kribiodosis fasciata Kieffer, I92I, ibid. $90: 43$ (sYN. Nov.).

Kribiodosis flaviventris Kieffer, I92I, ibid. $90: 44$ (sYN. Nov.).

A small dark species easily distinguished from other species of the subfamily by the narrow wings, bare squama, banded abdomen and the very long thin legs with the apices of femora and tibiae white. 
All Kieffer's material was from the same locality and the differences between the species are mostly of colour; three species were described from females alone, two from single specimens, the other two species (fuscithorax and fasciata) were known in both sexes. $K$. clavigera was separated mainly because the wings were feebly brown, but in the females available to me this is often so ; the main points of separation for the other four species lie in the colour and degree of fusion of the thoracic stripes and slight details of leg colour. However, as Kieffer's specimens were all in

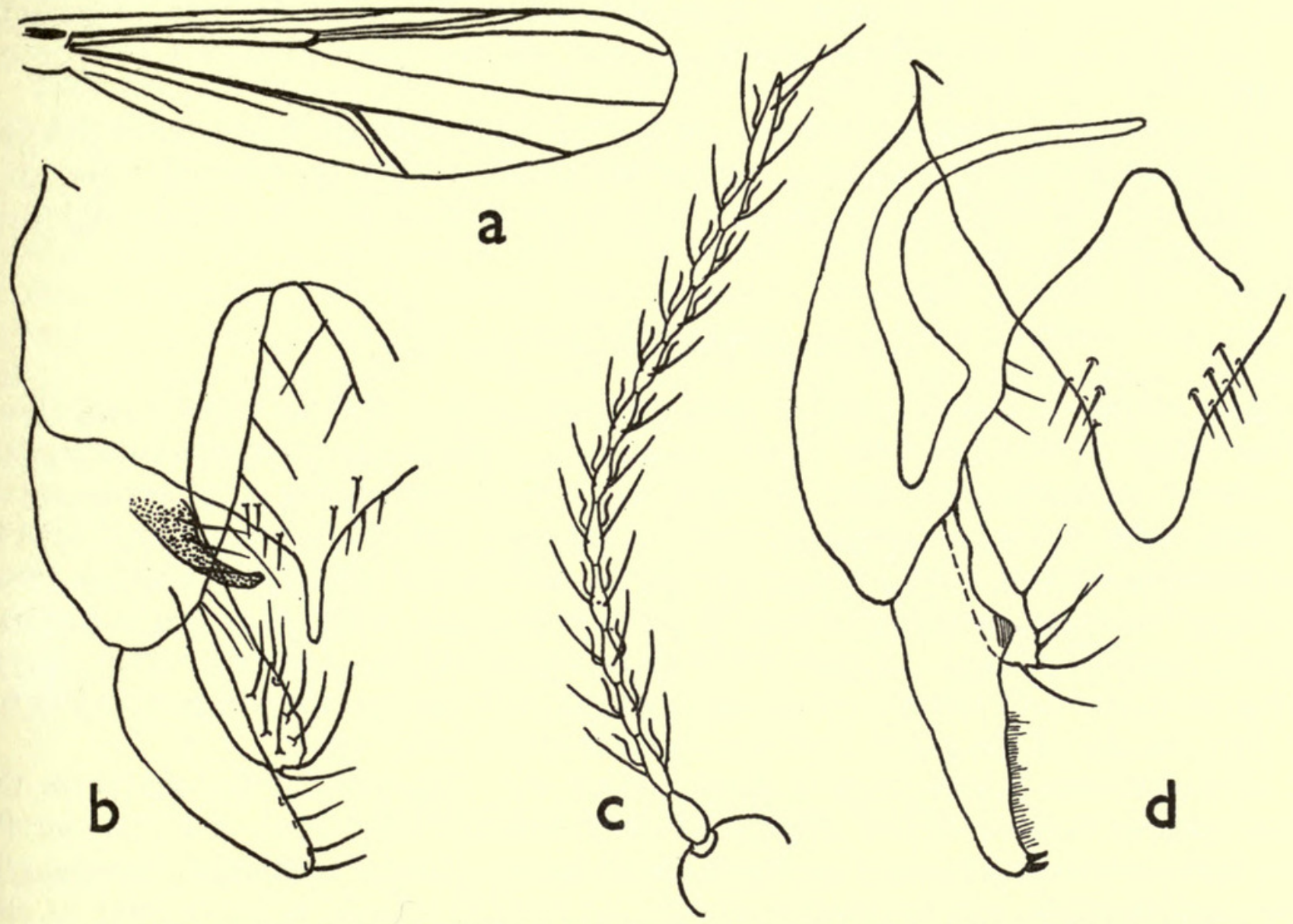

FIg. 9. Males of Kribiodosis and Kribiothauma. (a) Wing of Kribiodosis clavigera; (b) hypopygium of the same; (c) antenna of Kribiothauma pulchellum ; (d) hypopygium of the same.

spirit these characters are very unreliable and I prefer to regard all as redescriptions of the same species, for which I am using the first of his names.

Male. Wing length $\mathrm{I} \cdot 3-\mathrm{I} \cdot 5 \mathrm{~mm}$.

Head, mouthparts and antennae brown, flagellum whitish at the base, segmentation of antennae indistinct but usually I3 segments are present. A.R. about I; eyes rather close together above, narrow portion wider than usual, separation about half width of narrow portion. Thorax dark brown and shining, usually with some indication of darker stripes. Legs brown or yellowish brown, apices of femora and tibiae slightly clubbed and white, this is more noticeable on front legs than on others, femora may be rather darker just before white club ; legs long and thin, all femora ENTOM. $6, \mathrm{II}$. 
subequal, anterior tibia half length of femur, other tibiae nearly as long as femora; L.R. $2 \cdot 5$, segment 4 of front tarsus with three strong bristles projecting inwardly, basitarsus of middle legs slightly shorter than tibia, of posterior legs slightly longer than tibia; pulvilli barely noticeable. Wings usually clear, venation and shape as in Text-fig. 9, $a$; squama bare, halteres white. Abdomen yellowish brown, each segment with a dark ring posteriorly, styles white; hypopygium (Text-fig. $9, b)$ without unusual features.

Female essentially similar to male in colour and structure although wings may be slightly smoky; fourth segment of anterior tarsus simple, antennae with 5 segments.

The types of all of Kieffer's species are lost, all were from FRENCH CAMEROons : Kribi.

Distribution. Nigeria: i 옷 Abuja, xii.I954 (R. W. Crosskey). French West Africa: i9 0 , Moami, nr. Bobo Dioulasso, xi.I956 (J. Hamon). Belgian Congo: I ô, 8 o, Elisabethville, ii-iv.I939 (H. J. Brédo); 2 ㅇ, Likimi, xii.I927 (A. Collart).

\section{Genus LEPIDOPODUS gen. nov.}

Male unknown, female antenna with 7 segments, eyes slightly wider apart above than below, frontal tubercles absent, palpi long. Prothorax reduced centrally but produced laterally as a short tubercle each side; acrostichal and dorso-central bristles both present as complete rows. Legs long and slender, more or less as in Kribiodosis, clothed with adpressed scales as well as erect bristles; anterior tibial scale without spur, posterior tibia with a single long spur which is on the large inner comb; pulvilli absent. Wings without macrotrichia, $R_{2+3}$ separate from $R_{1}$ at apex, posterior fork beyond cross-vein, squama with incomplete fringe of 4-5 hairs.

Type species of the genus Chironomus nigratipes Kieffer, I9II.

Although only known from a single female the characters of the scales on the legs, curious prothorax and absence of both anterior tibial spur and also pulvilli are sufficient to distinguish it readily from all known genera. Although superficially like Lauterborniella and Kribiodosis it may not really be closely allied to them at all ; a male is necessary before its exact affinities can be determined.

\section{Lepidopodus nigratipes Kieffer}

Chironomus nigratipes Kieffer, I9I I, Trans. Linn. Soc. Lond. (Zool.) 14 : $35^{8}$.

Brown, abdominal segments broadly pale apically, knees and apices of tibiae yellow. Distinguished from other species of the subfamily by the presence of adpressed scales on the legs and by the tuberculate prothorax.

Female. Wing length $2 \cdot 25 \mathrm{~mm}$.

Head, mouthparts and antennae brown, pedicel and basal flagellar segment yellow, antennal segments fusiform, segment 7 equal to 5 and 6 together. Thorax brown, slightly pruinose along hair lines and lateral margins. Legs brown, apices of femora, knees and apices of tibiae yellow, clothed with adpressed narrow scales as well as erect bristles ; L.R. 2, anterior femur one and a half times as long as tibia, pulvilli 
absent. Wings unmarked, halteres pale. Abdomen brown, segments $2-6$ with broad yellow apices, segment I completely yellow, cerci yellow.

The holotype female is in the British Museum; type locality Seychelles: Mahé ; no other specimens are known.

\section{Genus KRIBIOTHAUMA Kieffer}

Kribiothauma Kieffer, I921, Ann. Soc. sci. Brux. 40 (I):270; Kieffer, 1921, Ann. Soc. ent. France, $90: 39$.

Male antenna with I4 segments, all flagellar segments more or less equal, the last not greatly elongated, without long plumes but with a whorl of about 4 short hairs (Textfig. 9,c), sensory hairs well developed and sinuous ; female antenna with 7 segments ; frontal tubercles absent; palpi of medium length only. Prothorax reduced, not visible from above, acrostichal and dorso-central bristles both present but short. Anterior tibia with strong curved spur, posterior tibia with a single spur, pulvilli present but not conspicuous. Wings broad and patterned, posterior fork short, $\mathrm{R}_{2+3}$ well separated from $\mathrm{R}_{1}$, squama fringed. Eighth segment of male abdomen quadrate, ninth conical, appendage I absent, struts well developed, somewhat similar to those of species of Corynoneurinae.

Type and only known species of the genus $K$. pulchellum Kieffer, I92I.

The affinities of this aberrant genus are not very obvious but on adult structure it seems best placed with Lauterborniella and its allies. The peculiar structure of the male antenna is similar in males both from French Cameroons and from Transvaal and render the male easily recognizable. The female can be separated from Lauterborniella by the presence of a squamal fringe.

\section{Kribiothauma pulchellum Kieffer}

Kribiothauma pulchellum Kieffer, I921, Ann. Soc. ent. France, 90 : 39.

A small species with heavily patterned wings, easily distinguished from other species by the peculiar male antennae, low L.R., presence of front tibial spur and squamal fringe and by the distinctive male hypopygium.

Male. Wing length $0.9 \mathrm{~mm}$.

Head brown, antennae as in Text-fig. 9, c, pedicel yellow. Thorax brown, more yellow in the centre anteriorly, slightly pruinose. Legs brown, tarsi yellow, L.R. hardly more than I. Wings blackish with clear spots as shown in Pl. 2, fig. $r$; halteres black. Abdomen dark brown; hypopygium (Text-fig. 9, d) with conical anal point, rounded at the apex, appendage 2 with about 5 hairs, styles with an inner projection near the base and two apical spines in the single specimen available to me.

Female not known to me, but similar to male according to Kieffer's description.

The type series is probably lost ; type locality FrenCH CAMERoons : Kribi.

Distribution. Apart from the type series known only from TransvaAl: I ô, Great Usutu River, nr, Amsterdam, ix. I954 (A. D. Harrison). 


\section{Genus KRIBIOXENUS Kieffer}

Kribioxenus Kieffer, 1921, Ann. Soc. sci.Brux. 40 (I) : 271 ; Kieffer, 1921, Ann. Soc. ent. France, $90: 29$ and 53 (not Goetghebuer, 1928, Edwards, 1929 and Townes, 1945-see Nilothauma).

I have not seen any specimens that agree with such diagnosis as Kieffer gives in his keys, I cannot, therefore, give a full generic diagnosis. It is separated by Kieffer from other genera because the male antennae have I4 segments with A.R. $0 \cdot 6$, the anterior tibia a short bristle-like spur, the posterior tibia a single spur, pulvilli very short or absent and wings unmarked. The genus is monotypic and the type species is $K$. pallidulus Kieffer.

Although I have been unable satisfactorily to recognize any species as belonging to this genus, it is quite clear from a study of Kieffer's description of the type species that Goetghebuer and Edwards misidentified the genus when they placed brayi Goetghebuer here instead of in Nilothauma. I have dealt with this at greater length under Nilothauma in Part III of the present series of Studies. It is quite possible that Kribioxenus is a synonym of Polypedilum as mentioned below.

\section{Kribioxenus pallidulus Kieffer}

Kribioxenus pallidulus Kieffer, 1921, Ann. Soc. ent. France, 90 : 53.

This was described from a yellowish white male, $\mathrm{I} \cdot 2 \mathrm{~mm}$. long, with mesonotal stripes and postnotum brown and anterior femur twice as long as the tibia. The male hypopygium as figured by Kieffer is shown with a widely triangular anal point with another wide plate beneath prolonged into a short lobe on its posterior margin. It seems probable that the latter is the true anal point and that the former is the VIIIth tergite into which the hypopygium has been telescoped.

It is not improbable that it is a small plain-winged species of Polypedilum close to or possibly synonymous with $P$. melanophilus Kieffer which also has a low antennal ratio.

Holotype male probably lost, locality French Cameroons : Kribi.

\section{Genus KRIBIOMYIA Kieffer}

Kribiomyia Kieffer, I921, Ann. Soc. sci.Brux. 40 (I) : 27I ; Kieffer, I921, Ann. Soc. ent. France, $90: 30$ and $91: 18$.

As with Kribioxenus I have seen no specimens that agree with the brief diagnosis given in Kieffer's keys. The genus was based on a plain-winged female which had broken antennae and which was separated from other genera mainly because the anterior tibia had a rounded scale which lacked a spur, the posterior tibia had a single spur, pulvilli were present and the wings unmarked. It could easily have been the female of a species of Polypedilum with broken front tibial spur, but with the inadequate diagnosis I prefer to treat it as genus incertae sedis.

Type species Kribiomyia longipalpis Kieffer by monotypy. 


\section{Kribiomyia longipalpis Kieffer}

Kribiomyia longipalpis Kieffer, 1921, Ann. Soc. ent. France, 91 : 18.

The only known specimen was a female, whitish yellow in colour, $2.5 \mathrm{~mm}$. long. The antennae were broken at the third segment; wings plain, halteres white, legs yellow, tips of anterior tibiae and posterior tarsi a little obscured; anterior femur nearly twice as long as tibia, anterior tarsi broken.

Holotype female probably lost, type locality French Cameroons : Kribi.

\section{TRIBE TANYTARSINI}

As explained in Part III, the Tanytarsini contains all the species of the Chironominae with not only macrotrichia on the wing membrane but also a bare squama and cross-vein parallel to and practically continuous with $\mathrm{R}_{4+5}$. In addition the male hypopygium has accessory appendages associated with appendages I or 2 or with both.

The genus Tanytarsus was used by van der Wulp for a number of species, two of which were punctipes Weidemann and signatus Wulp, the identity of signatus being certain but that of punctipes being open to some doubt. Kieffer (I909, Bull. Soc. Hist. nat. Metz, $26: 50$ ) as first reviser, restricted Tanytarsus sensu stricto to species without pulvilli, which would include signatus, but he did not fix a type species. This was done by Coquillett (I9I0, Proc. U.S. nat. Mus. 37:6I2) who fixed punctipes as the type species. Unfortunately, punctipes as determined by Edwards and now generally accepted, possesses pulvilli and belongs to Phaenopsectra, a group placed in the Chironomini. Therefore, if the Rules of Nomenclature are followed, the name Tanytarsus should be used for Phaenopsectra, whilst the group previously called Tanytarsus should be called by the next available name which is Calopsectra Kieffer. This would involve a change of the name of the Tribe to Calopsectrini as has already been done by Townes (I945, Amer. midl. Nat. 34 : II) who has been followed by some American Dipterists. Edwards, incorrectly, did not accept Coquillett's fixation on the grounds that it did not conform with Kieffer's restriction and in 1929 he proposed signatus as the type species.

The name Tanytarsus is now firmly entrenched in the literature and it is undesirable to change its meaning so drastically. I am, therefore, preparing a case for submission to the International Commission for Zoological Nomenclature asking that Coquillett's fixation should be set aside in favour of the later one by Edwards. For the time being I am continuing to use the name Tanytarsus in its usually accepted sense.

The species of the Tribe are all small or very small and difficult to distinguish from each other. Very few can be separated without examination of the male hypopygium which renders many of Kieffer's species quite unrecognizable.

Kieffer has described 23 species in the tribe from Africa south of the Sahara, two of which (glabripennis and alticola) belong to the Chironomini, genus Polypedilum. Of the remainder, I3 are based on females alone and cannot be recognized, whilst of 
the last eight only four have descriptions sufficient for their recognition. Short notes are given on the unrecognized species at the end of the Tribe.

Goetghebuer has described three species and I have described II, all of which are redescribed and figured below.

\section{Key to African Genera of Tribe Tanytarsini}

I. Combs of posterior tibia without spurs, large and overlapping, thus appearing to be fused (African species only) . . . . . . . . Micropsectra Kieffer Combs of posterior tibia small, well separated and usually both with spurs . . 2

2. Eyes pubescent, small species with cuneiform wings . . . . Zavrelia Kieffer Eyes bare

3. Both combs usually spurred ; wings not cuneiform; $\mathbf{R}_{\mathbf{4 + 5}}$ longer, ending beyond tip

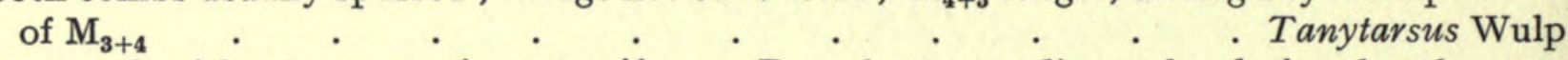
One comb without spur ; wings cuneiform ; $R_{4+5}$ shorter, ending at level of, or basal to, tip of $\mathrm{M}_{3+4} \quad$. $\quad . \quad . \quad . \quad . \quad . \quad . \quad . \quad . \quad . \quad$ Stempellina Bause

\section{Genus MICROPSECTRA Kieffer}

Micropsectra Kieffer, 1909, Bull. Soc. Hist. nat. Metz, 26 : 50 ; Goetghebuer, 1938, in Lindner, Flieg. Pal. Reg. 3 (13c): 84.

Tanytarsus subg. Micropsectra Edwards, 1929, Trans. ent. Soc. Lond. $77: 407$.

Male antennae I4-segmented, frontal tubercles absent; combs of four posterior tibiae lacking spurs, fused in Palaearctic species but separate and overlapping in the single African species ; r-m cross-vein two or three times length of basal section of Rs.

The only known African species is represented by a single specimen from South Africa. It is not completely typical of the genus because of the condition of the combs which are so close that they overlap, a condition which I have not found in any of the Palaearctic species available to me. However, as in other ways the species falls into this genus I prefer to leave it there rather than erect a new genus.

\section{Micropsectra capicola Freeman}

Micropsectra capicola Freeman, 1955, S. Afr. Animal Life. Uppsala, 2 : 379.

Scutal stripes fused, shoulders yellowish, abdomen yellowish with dark bands, legs brown, combs unarmed but not fused, wings densely hairy, hypopygium with three appendages.

Male. Wing length $2 \cdot 2 \mathrm{~mm}$.

Head yellowish brown, frontal tubercles absent, pedicel brown, A.R. about o.8. Thorax with yellowish ground colour, stripes dark brown and fused, scutellum, postnotum and sternopleuron brown, prescutellar area pale brown; acrostichal bristles irregularly biserial, dorso-centrals uniserial. Legs brown and unmarked, anterior tibia two-thirds length of femur, tarsus missing ; posterior basitarsus twothirds length of tibia, pulvilli absent, claws rather small ; combs unarmed, occupying about three-quarters of circumference of tibia, appearing fused at first sight but on closer inspection from the side they are seen to be separate but overlapping 
or touching. Wings densely clothed all over with macrotrichia, squama bare, $\mathrm{r}-\mathrm{m}$ about three times length of base of Rs; halteres yellow. Abdomen yellowish with brown bands at the incisures; hypopygium (Text-fig. Io, a) with three appendages, $\mathrm{I} a$ absent, $2 a$ transverse and with simple hairs only.

Female not known.

Holotype male in collection of the Lund University Museum; type locality CAPE PRovince: Hermanus Waterfall; no other specimens known.

\section{Genus TANYTARSUS van der Wulp}

Tanytarsus van der Wulp, 1874, Tijdschr. Ent. 17 : 134; Goetghebuer, 1938, in Lindner, Flieg. Pal. Reg. 3 (13c) : 105.

Tanytarsus subg. Tanytarsus Edwards, 1929, Trans. ent. Soc. Lond. $77: 409$.

Combs of posterior tibiae at least narrowly separated ventrally, occupying at most half circumference of tibia, usually both with a spur but inner one often shorter and occasionally absent. Male antenna I3- or I4-segmented, of female 5-7-segmented. Wing membrane with a variable number of macrotrichia, $R_{4+5}$ ending at level of, or more usually beyond tip of $\mathrm{M}_{3+4}$, posterior fork usually well beyond cross-vein, tip of $\mathrm{M}_{3+4}$ often slightly sinuous, anal area always more or less developed. Scutellum usually with several long marginal bristles but in small species the central pair is the longest.

I am using Tanytarsus in a more restricted sense than it was used by Edwards, to include only those groups which he placed in his subgenus Tanytarsus; I am treating most of his species groups as subgenera, a treatment which conforms with that of Goetghebuer. I have discussed the validity of the generic name above.

Tanytarsus used in this way includes most of the species of the tribe and can be recognized by the combs and tibial spurs, shape of wings and length of $R_{\mathbf{4 + 5}}$. It can be divided into groups of species mainly on male genital characters, groups which have often been regarded previously as genera, but it is my opinion that they cannot be accorded a higher rank than subgenus because of the absence of similar characters in the female.

Separation of the species is not easy especially as they are subject to considerable variation particularly in colour ; the only reliable characters lie in the structure of the male genitalia, though here again there is variability. I am able to recognize 25 African species, falling into four subgenera but no doubt others will be found when there has been wider collecting of these tiny insects.

\section{Key to Subgenera of Tanytarsus from Africa South of the Sahara}

I. Pulvilli present; male anal point with reflexed appendages in both the known African species

Pulvilli absent; reflexed appendages absent

Calopsectra Kieffer

2. Appendage $2 a$ of the male hypopygium with branched hairs, styles rather short

Appendage $2 a$ with hairs simple or flattened

Cladotanytarsus Kieffer

3. $R_{1}$ and $R_{4+5}$ close together and obliterating $R_{2+3}$; male styles contracted at apex or for apical half

Rheotanytarsus Bause $R_{2+3}$ present, styles evenly pointed or rounded at apex

Tanytarsus v. d. Wulp 


\section{Tanytarsus VAN DER WULP SUBGENUS Tanytarsus SENSU STRICTO}

Tanytarsus van der Wulp, I874, Tijdschr. Ent. 17 : 134 .

Tanytarsus subg. Tanytarsus Group D, Edwards, 1929, Trans. ent. Soc. Lond. 77 : 413.

Tanytarsus subgenus Tanytarsus Goetghebuer, 1938, in Lindner, Flieg. Pal. Reg. 3 (I3c): 105;

Brundin, 1947, Avkiv. Zool. 39A no. $3: 67$.

This subgenus includes all the species of the genus without special characters enabling them to be split off as separate groups; most of the species fall here. Pulvilli absent or indistinct, frontal tubercles usually present, male styles not sharply contracted at apex, appendage $2 a$ with simple, unbranched hairs. There are two species groups, those with simple anal point and those with a longitudinal row of dots placed between keels.

\section{Key to African Species of Tanytarsus s. Str., Based on Male Characters}

I. Anal point of male simple

Anal point of male with longitudinal row of dots as in Text-fig. I I

2. Legs yellow with black tips to femora and to tibiae and tarsal segments; abdomen yellow with distinctive black bands and longitudinal markings .

. balteatus Freeman

Legs unmarked or only apices of femora vaguely darkened .

3. Appendage $\mathrm{r} a$ absent

Appendage $\mathrm{r} a$ present

4. Appendage $2 a$ short and rounded (Text-figs. Io, $c, d$ ) .

Appendage $2 a$ elongate (Text-fig. 1o, $e$ )

5. Abdomen plain green

Abdomen with broad dark bands on segments 2, 3, 6 and 8 .

6. Wings with macrotrichia over most of surface

Matrotrichia reduced, present only at apex and sometimes as lines along centre of some cells

7. Anal point bifid (Text-fig. ro, $g$ )

Anal point simple

8. Appendage $2 a$ rounded (Text-fig. Io, $f$ )

Appendage $2 a$ elongate (Text-fig. Io, $h$ )

9. Body of male entirely black, frontal tubercles absent .

Body of male at least partially yellow or green .

10. Thorax dull, partially pruinose, hypopygium as in Text-fig. I I, $a$.

Thorax shining, without pruinosity, hypopygium as in Text-fig. I I, $b$

II. Thoracic markings brown

Thoracic markings yellow

I2. Abdomen plain green, appendage $2 a$ trifid (Text-fig. II, $h$ ) .

Abdomen with dark markings .

..$\quad 3$

- angustus Freeman pallidulus Freeman atrocinctus Goetgbenuer pallidissimus Kieffer

3. Appendage I more or less square (Text-fig. I I, $d$ ), abdomen green with pale brown ring on each segment, tarsal beard absent . . . . . spadiceonotatus $\mathrm{sp} . \mathrm{n}$.

Appendage I more elongate (Text-fig. II, c), abdomen much darker and with a median longitudinal dark stripe, tarsal beard present . . nigrocinctus Freeman

I4 Abdominal segments each with a brown ring, male hypopygium as in Text-fig. II, $e$, appendage I broad, I $a$ short, anal point broad.

Abdomen quite plain

I5. Anal point narrow, styles curved (Text-fig. II, $f$ ) mcmillani sp. $\mathrm{n}$. Anal point broader, styles straighter (Text-fig. II, $g$ ) .

flexistilus sp. $\mathrm{n}$. . zariae sp. n. 


\section{Tanytarsus (Tanytarsus) balteatus Freeman}

Tanytarsus (Tanytarsus) balteatus Freeman, 1955, Explor. Parc Nat. Albert, Miss. de Witte, fasc. 83: 36 ; Freeman, 1955, S. Afr. Animal Life. Uppsala, $2: 38$ o.

Thorax pale with a broad vertical brown stripe on the pleura and brownish markings on the stripes; legs yellow with black tips to femora, tibiae and tarsal segments, only one tibial spur; abdomen yellow with distinctive black bands and longitudinal markings on segments $\mathrm{I}-5$; male hypopygium without row of dots on anal point, appendage $2 a$ large and with fan-like arrangement of strong setae. The colour pattern makes this species easily determinable in both sexes.

Male. Wing length $\mathrm{I} \cdot 75^{-2} \cdot 0 \mathrm{~mm}$.

Head yellowish brown; face mouthparts and scape dark brown; A.R. about I.2, frontal tubercles present. Thorax with pale yellow pruinose ground colour, scutal stripes short, fused and pale brown but darker brown at posterior end of middle stripe and anterior ends of lateral stripes giving a cross-banded appearance ; this cross band is continued down each pleuron and on to the sternopleuron ; postnotum brown, darker at the apex. Legs yellow, apices of all femora and of tibiae broadly black, apices of tarsal segments also dark; L.R. $2 \cdot 2$, pulvilli absent, combs well separated, only the outer one with a spur. Wings with macrotrichia on apical half, $\mathrm{R}_{4+5}$ ending beyond $\mathrm{M}_{4+5}$; halteres whitish. Abdomen yellow with black markings on segments $I, 2,3,5,6$; segments $I-3$ with a median longitudinal black band which expands laterally to form a transverse band near the posterior margin, margin itself pale ; there is a short longitudinal pale line placed posteriorly in each black marking; segment 5 with a similar black marking not so well developed, segment 6 all black. Hypopygium (Text-fig. Io, $b$ ) with short anal point lacking row of dots, appendage I more or less square, I $a$ rather stout, $2 a$ large and with a fan-like arrangement of strong setae, styles narrow.

Female with markings as in male, macrotrichia more numerous on wing membrane, antennae with 6 segments, although the last 2 are indistinctly separated.

Holotype male in the British Museum.

Distribution. SUdAN : holotype and paratypes, Adok; other paratypes and further material, Melut and Shambe (E.T.M. Reid). Nigeria : II ô, I o, Kankiya, xii.I956-i.I957, I ô, Kaduna, x.I956 and I ô, Katsina, x.I956 (B. McMillan). Uganda : $4 \hat{0}, 5$ , Jinja, ix-x.I954 (P. S. Corbet). Belgian Congo: paratypes from Parc National Albert. S. RHodesia : I q, Salisbury, v. I956 (E. T. M. Reid). S. W. Africa : 6 б, 23 ㅇ, Kaokoveld (P. Brinck).

\section{Tanytarsus (Tanytarsus) pallidulus Freeman}

Tanytarsus (Tanytarsus) pallidulus Freeman, 1954, Proc. R. ent. Soc. Lond. (B) 23 : 24 ; Freeman, 1955, Explor. Parc Nat. Albert, Miss de Witte, fasc. 83:35; Freeman, 1955, S. Afr. Animal Life. Uppsala, $2: 380$.

Pale green with yellowish scutal stripes, frontal tubercles present, both tibial combs spurred, macrotrichia present over most of wing surface, appendage $2 a$ of male hypopygium short and with simple hairs ; most easily separated from other green species by the male hypopygium. 


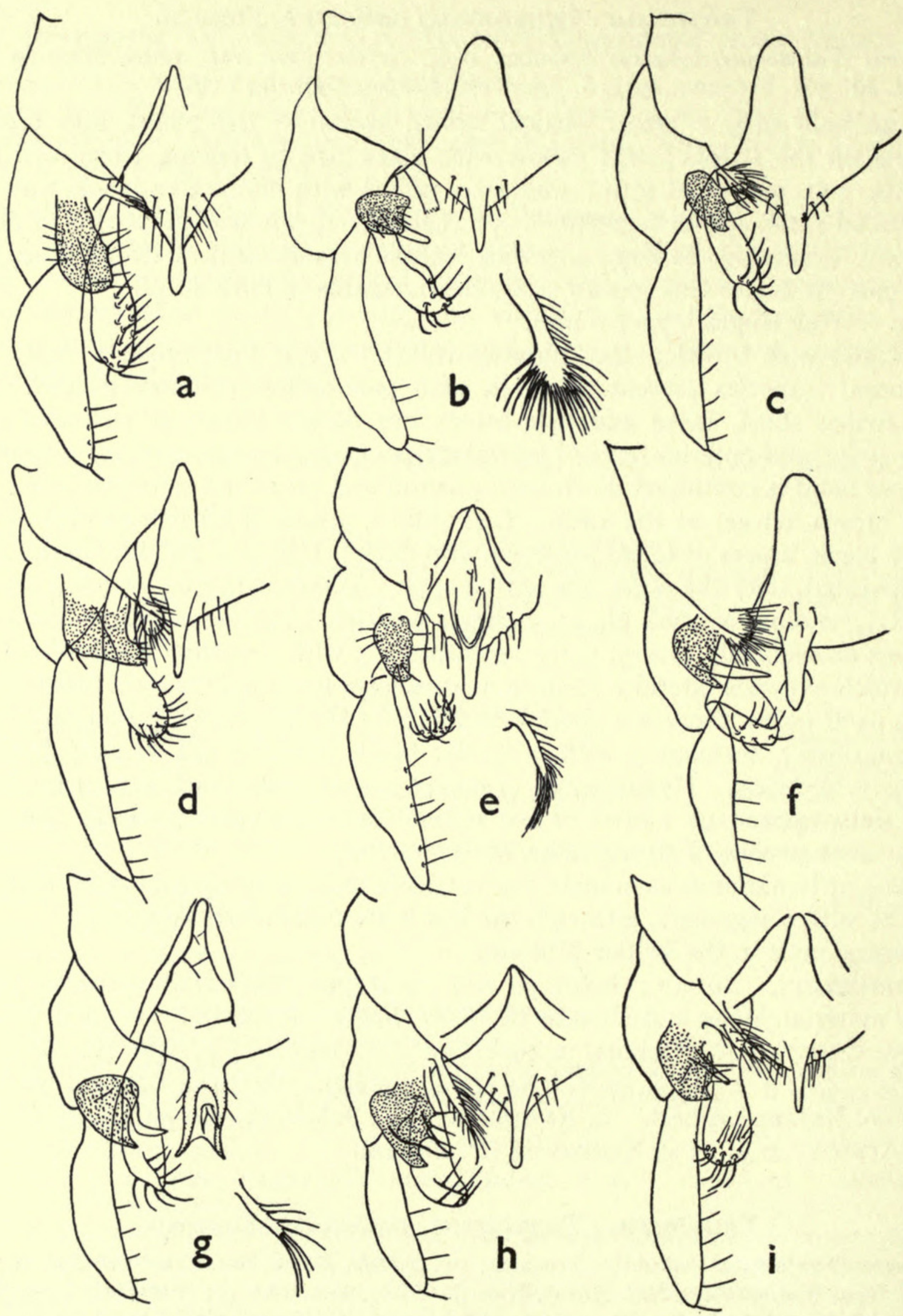

Fig. Io. Male hypopygia of Micropsectra and Tanytarsus (Tanytarsus). (a) M. capicola; (b) $T$. balteatus with appendage $2 a$ drawn separately; (c) $T$. pallidulus; (d) T. atrocinctus; (e) T. angustus; (f) $T$. nocticolor; (g) $T$. bifurcus ; (h) $T$. atomarius; (i) $T$. pallidissimus. 
Male. Wing length $2-2.5 \mathrm{~mm}$.

Head and mouthparts yellowish green, antennae brown, pedicel reddish yellow, A.R. about I.4, frontal tubercles present. Thorax pale yellowish green, scutal stripes, postnotum, sternopleuron yellow. Legs pale, L.R. 3, tibial combs well separated, each with a spur, that on outer comb the longer. Wings with macrotrichia over most of surface, bare tracts along some veins in basal half; halteres greenish. Abdomen green; hypopygium (Text-fig. Io, c) with well-defined anal point lacking row of dots, styles pointed and slightly curved; appendage I fairly broad, I $a$ absent, $2 a$ short and rounded, clothed with simple hairs.

Female similar to male in colour ; antennae with 6 segments, wings more uniformly clothed with macrotrichia.

Holotype male in the British Museum.

Distribution. CAPE Province : holotype, Kirstenbosch ; 2 ㅇ, 4 으, Stellenbosch and Tulbagh Barrage (K.M.F.Scott) ; 3 ô, Ceres, iii.I925 (R. E. Turner). Trans-

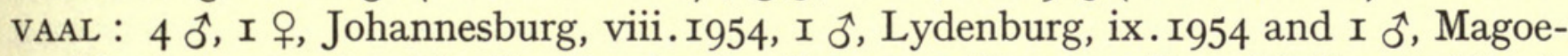
baskloof, iv-v.I955 (A. D. Harrison). Belgian Congo: Parc National Albert. Nigeria : 2 ô, Kankiya, xii.r956-i.I957 (B. McMillan).

\section{Tanytarsus (Tanytarsus) atrocinctus Goetghebuer}

Tanytarsus atrocinctus Goetghebuer, 1936, Rev. Zool. Bot. Afr. $28: 490$.

Yellowish, abdomen with broad dark bands on segments 2, 3, 6 and 8 which distinguishes it from other species; wings evenly clothed with macrotrichia, male hypopygium not unlike pallidulus but appendage I much bigger. A.R. only $0 \cdot 6$.

Male. Wing length $\mathrm{I} \cdot 3 \mathrm{~mm}$.

Head, mouthparts and pedicel yellow, flagellum brown, A.R. $0 \cdot 6$, frontal tubercles probably absent. Thorax yellowish; stripes, postnotum and sternopleuron reddish. Legs uniformly pale, L.R. 2·5, both combs of posterior tarsus with spurs. Wings uniformly clothed with macrotrichia, halteres black-tipped. Abdomen with segment I greenish yellow, 2 and 3 each with a broad brown band leaving only incisures yellowish, 4 and 5 yellowish, 6 brown, 7 paler but brown basally, 8 brown. Hypopygium (Text-fig. Io, $d$ of holotype) not unlike pallidulus but appendage I much bigger ; $\mathrm{I} a$ absent, $2 a$ rounded, anal point well formed and without dots.

Female not known.

I have seen the holotype male which is in the Musée Royal du Congo Belge, Tervuren.

Distribution. Known only from the type and paratype, Belgian Congo: Rutshuru.

\section{Tanytarsus (Tanytarsus) angustus Freeman}

Tanytarsus (Tanytarsus) angustus Freeman, 1955, Explor. Parc Nat. Albert, Miss. de Witte, fasc. $83: 35$.

Greenish with yellow thorax; A.R. I·2, frontal tubercles absent. Very similar to pallidulus, distinguished by absence of frontal tubercles and by appendage $2 a$ being elongate and not short and rounded. 
Male. Wing length $\mathrm{I} \cdot 8-2 \cdot 0 \mathrm{~mm}$.

Head yellow, antennae and mouthparts brownish; A.R. I.2, frontal tubercles absent. Thorax yellow, scutal stripes hardly darker. Legs yellow, L.R. 2.2, combs separate and each with a spur. Wings clothed all over with macrotrichia, halteres pale. Abdomen pale green; hypopygium (Text-fig. Io, $e$ ) with welldeveloped anal point lacking row of dots, style pointed, appendage I similar to pallidulus, I $a$ absent, $2 a$ long and with simple hairs.

Female resembles male, antennae 6 segmented, 5 and 6 indistinctly separated.

Holotype male in collection of Institut Royal des Sciences Naturelles de Belgique.

Distribution. Belgian Congo: holotype and paratypes Parc National Albert, Riv. Bishakishaki and Riv. Molindi ; further series in spirit, Kivu, Luhanga, vi. I955 (G. Marlier).

Seven males (Nigeria : Kankiya, xii.I956-i.I957, B. McMillan) are structurally indistinguishable but have dark markings on the thorax, dark bands at apices of abdominal segments and apices of femora dark ; this may represent a variety or a distinct species.

\section{Tanytarsus (Tanytarsus) nocticolor Kieffer}

Tanytarsus nocticolor Kieffer, 1911, Rec. Ind. Mus. 6 : 171.

Frontal tubercles present, thorax yellow with brown stripes, legs unmarked, both combs spurred, abdomen green, wings with reduced macrotrichia; hypopygium with appendage I beaked, $2 a$ squat and with bushy hairs. The reduced macrotrichia and presence of appendage $\mathrm{I} a$ are sufficient to distinguish this species from pallidulus and atrocinctus which are the only other species with rounded appendage $2 a$.

Male. Wing length $\mathrm{r} \cdot 5 \mathrm{~mm}$.

Head yellowish, frontal tubercles present, A.R. about I. Thorax yellowish; stripes, postnotum and sternopleuron brown. Legs yellowish, unmarked, L.R. 2.5 , both combs spurred, that on outer comb being the stronger. Wings with $R_{4+5}$ ending opposite tip of $\mathrm{M}_{3+4}$, macrotrichia present only at extreme apices of cells $\mathrm{R}_{5}$ and $\mathrm{M}_{2}$ and as a single row along centre of apical two-thirds of former; halteres pale. Abdomen green; hypopygium (Text-fig. Io, $f$ ) with simple anal point, appendage I with a beak, I $a$ long, 2 rather short and broad, $2 a$ short, squat and with a brush of simple hairs.

Female similar to male though thorax may be paler, but wings with macrotrichia at apex of fork cell, as a line in cell $\mathrm{M}_{2}$ and around margin of anal cell in addition; antennae with 6 segments.

Holotype female is in the British Museum and can be recognized because of the reduction of the macrotrichia and by the brown scutal stripes.

Distribution. EgYPT: holotype female, Suez Canal; I $\hat{0}$, Assuan, i.I923 (S. Hirst). Sudan : I4 ô, 8 o, Khartoum, I-ii.I923 (S. Hirst); I4 ô, I5 ㅇ, Wad Medani, ii.rg52 (D. J. Lewis). Belgian Congo: I $\widehat{o}$, Kasenyi (Lac Albert), xii. 1953 (J. Verbeke). 


\section{Tanytarsus (Tanytarsus) bifurcus sp. $\mathrm{n}$.}

A small yellow and green species with darker thoracic stripes; A.R. $0 \cdot 6$, frontal tubercles present, wing macrotrichia reduced, tibial combs with two spurs. Easily distinguished from nocticolor and others by the highly characteristic forked anal point which carries two erect lobes between the arms of the fork.

Male. Wing length $\mathrm{r} \cdot \mathrm{o} \mathrm{mm}$.

Head yellowish, pedicel brown, frontal tubercles present, A.R. 0.6. Thorax yellowish, stripes and postnotum brown, scutellum with two long marginal setae close together and a shorter one laterally. Legs whitish, L.R. $2 \cdot 5$, combs each with a spur, that on outer one the longer. Wings nearly cuneiform, $\mathrm{R}_{4+5}$ ending beyond level of apex of $\mathrm{M}_{3+4}$, macrotrichia present at apices of cells $R_{5}, M_{2}$ and fork cell and as lines down centre of each cell and along margin of anal cell; halteres white. Abdomen green; hypopygium (Text-fig. Io, g) with peculiar anal point; main body of point broad, thickened each side, emarginate at apex and appearing forked ; between the thickened margins are two erect pointed lobes; appendage I more or less triangular and beaked, I $a$ sinuous and well formed, $2 a$ with simple hairs. Female not known.

Holotype male and 4 o paratypes French West AfricA, Haute Volta : Tangrela (Cercle de Banfora), xii.I956 (J. Hamon). Holotype and two paratypes returned to Office de la Recherche Scientifique Outre-Mer, two paratypes in the British Museum.

\section{Tanytarsus (Tanytarsus) atomarius Kieffer}

Tanytarsus atomarius Kieffer, 1918, Ann. Mus. nat. Hung. $16: 72$.

? Tanytarsus pallidissimus Kieffer, I91 I, Proc. Linn. Soc. Lond. Zool. 14 : 358 (in part).

A tiny green species with yellow thoracic stripes, A.R. 0.5, frontal tubercles present, apex of $\mathrm{R}_{4+5}$ opposite tip of $\mathrm{M}_{3+4}$, macrotrichia greatly reduced, combs both spurred, hypopygium with all appendages well developed. Although Kieffer described atomarius from a female, the small size, reduced macrotrichia, short radius and green colour make if fairly certain that I have identified the species correctly. As explained under pallidissimus the type series of that species is mixed, half being very similar to but with wings slightly more hairy than typical atomarius.

Male. Wing length $0 \cdot 8-\mathrm{I} \cdot 0 \mathrm{~mm}$.

Head greenish yellow, pedicel brown, A.R. 0.5, frontal tubercles present. Thorax green with yellow stripes, postnotum and sternopleuron. Legs yellow, L.R. 2.5, each comb of posterior tibia with a spur. Wings narrow but not cuneiform, $\mathrm{R}_{\mathbf{4}+5}$ ending opposite tip of $\mathrm{M}_{3+4}$, posterior fork well distal to cross-vein, macrotrichia reduced in Transvaal specimens to a small group at extreme apex and a row along centre of distal half of cell $R_{5}$; Seychelles material has an additional group and row in cell $\mathrm{M}_{2}$ and in fork cell. Halteres green. Abdomen green; hypopygium (Textfig. Io, $h$ ) with narrow and simple anal point, wide appendage I and $\mathrm{I} a, 2$ with only $5^{-6}$ hairs at tip, $2 a$ with simple hairs. 
Female. In the holotype and Seychelles specimens the thoracic markings are yellow but in the Transvaal specimens they are brown; antennae with 5 segments, macrotrichia more abundant than in male, present at apices of cells $R_{5}, M_{2}$ and fork cells and as lines along the centres of these cells and around margin of anal cell.

I have seen the holotype female of atomarius which was in the Hungarian National Museum.

Distribution. Transvaal: holotype, Pretoria ; 2 ô, Pongola River Settlements and I 우, Great Usutu River, near Amsterdam, ix.I954 (A. D. Harrison). Seychelles : $3 \hat{0}, 3$ ㅇ, cotypes of pallidissimus, Mahé, probably belong here.

\section{Tanytarsus (Tanytarsus) pallidissimus Kieffer}

Tanytarsus pallidissimus Kieffer, I9I I, Trans. Linn. Soc. Lond. Zool. 14 : $35^{8}$.

A pale greenish insect with yellow thoracic markings ; A.R. 0.5 , frontal tubercles present, L.R. $2 \cdot 8$, combs with two spurs ; wings fairly evenly clothed with macrotrichia, hypopygium with $\mathrm{I} a$ present, $2 a$ with simple hairs. The type series contained two species, the smaller of which appears to be atomarius (see above) with wings rather more hairy than usual.

Male. Wing length $\mathrm{I} \cdot 3-\mathrm{I} \cdot 4 \mathrm{~mm}$.

Head and antennae yellow, A.R. 0.5, frontal tubercles present. Thorax green, stripes and postnotum yellow, scutellum with two long hairs placed close together near the centre. Legs pale yellowish, L.R. 2·8, each comb with a spur. Wings with macrotrichia fairly evenly arranged over most of the surface, $\mathrm{R}_{4+5}$ ending well beyond level of tip of $\mathrm{M}_{3+4}$. Abdomen pale green; hypopygium (Text-fig. $\mathrm{Io}, i$ ) differs from atomarius by the narrower appendage $\mathrm{I} a$; appendage $\mathrm{I}$ with less well developed apical beak in paratype, thus appearing nearly oval, 2 with numerous hairs, $2 a$ straight and with simple hairs.

Female similar to male, antennae with 6 segments.

There are ten specimens of the type series in the British Museum all from SEychelles: Mahé ; six are ? atomarius, of the remaining $2 \hat{0}, 2$ ㅇ, I have marked one male as lectotype. No further material is known.

\section{Tanytarsus (Tanytarsus) aterrimus Freeman}

Tanytarsus (Tanytarsus) aterrimus Freeman, 1954, Proc. R. ent. Soc. Lond. (B) 23 : 179 ; Freeman, 1955, S. Afr. Animal Life. Uppsala, $2: 380$.

A fairly large species, body of male entirely black, halteres and legs paler, female paler with separate thoracic stripes ; frontal tubercles absent, anal point with row of dots, appendage $1 a$ present, $2 a$ bent ; wing hairs moderately dense. Distinguished from luctuosus, the only other African black species known to me, by the pale halteres, pruinose hair lines and structure of male hypopygium.

Male. Wing length $2-2.5 \mathrm{~mm}$.

Head, mouthparts and antennae very dark brown, pedicel black, A.R. 0.9 , frontal tubercles absent. Thorax entirely black, dull and with black hair, lines of bristles 
pruinose. Legs brown, L.R. $2 \cdot 0$, front tarsus not bearded, combs each with a spur, the outer spur slightly the longer. Wings with macrotrichia in apical half, a line in basal cell and some in middle of anal cell, most veins in apical half with bare tracts alongside ; halteres pale or with a tinge of brown. Abdomen black; hypopygium (Text-fig. II, $a$ ) with irregular row of about Io dots on anal point, appendage I oval and emarginate on inner margin, appendage $\mathrm{I} a$ well formed, appendage $2 a$ elbowed at the base and with a brush of simple hairs at the apex.

Female rather browner than male, thorax with paler background and more or less separate stripes, antennae with 5 segments the last 2 being fused; wing hairs denser than in male and numerous in basal half especially in the anal cell.

Holotype male in the British Museum.

Distribution. Cape Province: holotype male and type series of both sexes, Berg River, Assegaibos, Driefontein and Tulbagh Barrage; I $\hat{0}, 2$ 우, Ladismith (P. Brinck). TransvaAl : 3 $\delta$, Olifantsvlei nr. Johannesburg, viii. I954 and 2 o, I + , Magoebaskloof, iv-v.I955 (A. D. Harrison).

\section{Tanytarsus (Tanytarsus) luctuosus sp. n.}

Another entirely black species, at least in the male, distinguished from aterrimus by the slightly shining thorax which lacks pruinosity, by the black halteres and greatly developed appendage $2 a$.

Male. Wing length $\mathrm{I} \cdot 4 \mathrm{~mm}$.

Head, antennae and mouthparts black, A.R. $0 \cdot 8$, frontal tubercles absent. Thorax black with black bristles and slightly shining, hair lines without pruinosity. Legs dark brown, L.R. $2 \cdot 0$, pulvilli and tarsal beard absent, only the outer comb of posterior tibia with a spur. Wings with macrotrichia arranged much as in aterrimus halteres black. Abdomen black; hypopygium (Text-fig. II, $b$ ) with irregular double row of very small dots on anal point, appendage I narrow apically in holotype as shown, in the paratype with a small expansion near the tip, I $a$ absent, 2 rather small, $2 a$ long and curved and with long curved hairs.

Female not known.

Holotype male, Cape Province: Platteklip Gorge, i.r953 (K. M. F. Scott); paratype I $\delta$, TransvaAl: Magoebaskloof, nr. Tzaneen, v.I955 (A. D. Harrison). Both specimens are in the British Museum.

\section{Tanytarsus (Tanytarsus) nigrocinctus Freeman}

Tanytarsus (Tanytarsus) nigrocinctus Freeman, 1957, Explor. Hydrobiol. Kivu, Ed. Albert. Bruxelles, 3 : 220.

Yellowish, thoracic stripes dark brown, abdomen with dark rings and a median dark stripe; legs pale without distinct markings; frontal tubercles present, anterior tarsi with a slight beard. Distinguished from other species by the generally dark appearance, though not totally black as in males of aterrimus and luctuosus, as well as by details of the male hypopygium.

Male. Wing length $\mathrm{I} \cdot 6-2 \cdot 0 \mathrm{~mm}$. 
Head yellowish, mouthparts and antennae brown, frontal tubercles well developed, A.R. 2•0. Thorax yellowish with brown markings on the stripes, especially on the lateral ones, on the sternopleuron and postnotum. Legs yellow, L.R. $2 \cdot 5$, anterior tarsi with a scanty beard, combs well separated, each with a spur. Wings with

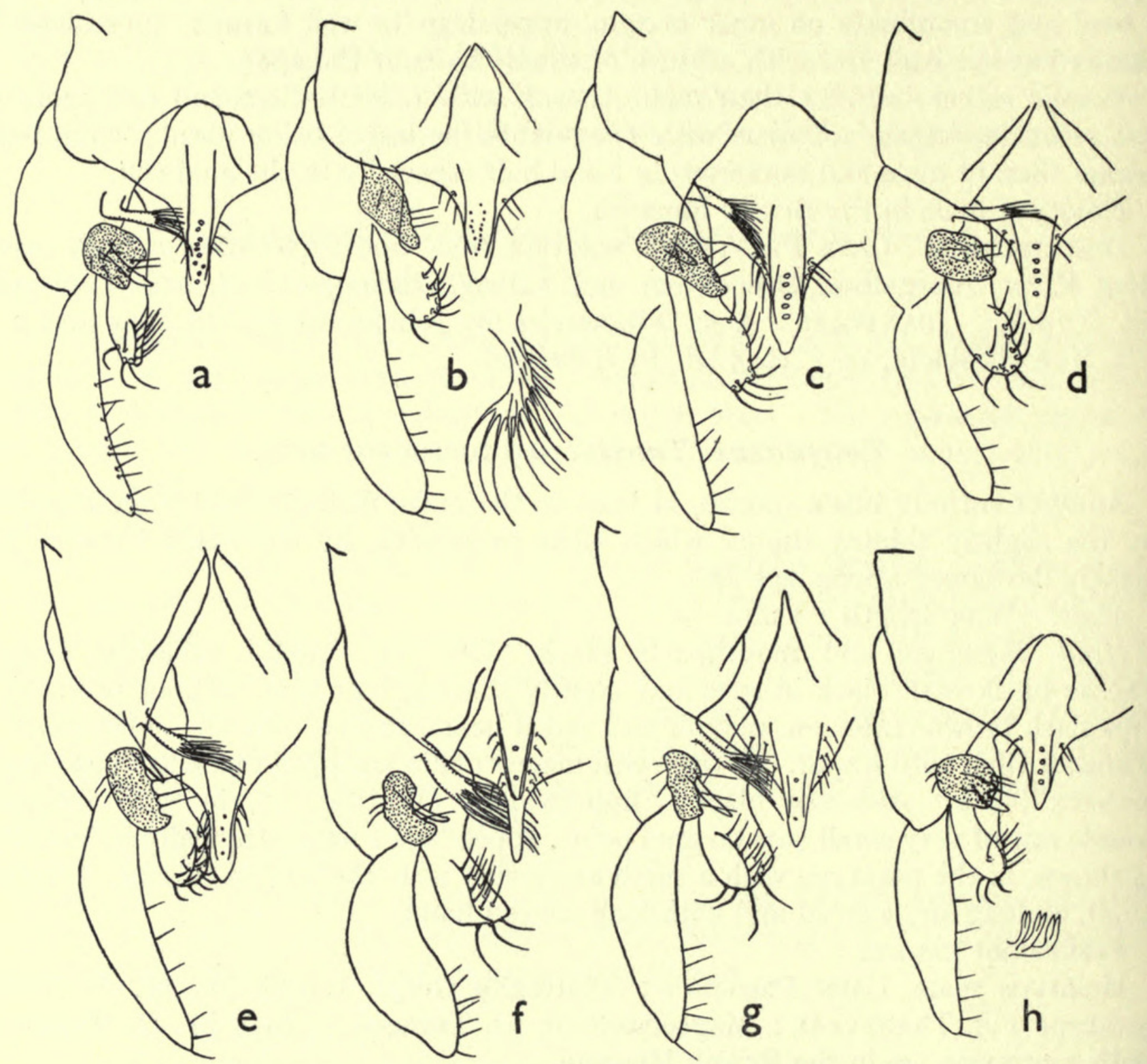

FIg. II. Male hypopygia of Tanytarsus (Tanytarsus). (a) T. aterrimus; (b) T. luctuosus with appendage $2 a$ drawn separately; (c) T. nigrocinctus; (d) $T$. spadiceonotatus; (e) T. momillani; (f) T. flexistilus; (g) $T$. zariae; (h) $T$. trifidus with appendage $2 a$ drawn separately.

macrotrichia at apices of cells $R_{5}, M_{2}$ and $M_{4}$ and as single rows in cells $R_{5}$ and $M_{2}$; halteres whitish. Abdomen greenish or brownish yellow with apical third of segments 2-7 black, segments I and 8 wholly black, 2-7 with a dark longitudinal stripe in addition to the apical bands. Hypopygium (Text-fig. II, $c$ ) with a row of about 5-6 large dots on anal point, appendage I narrow, I $a$ short, $2 a$ fairly small and with a brush of simple hairs at apex. 
Female very similar to male ; abdomen more evenly dark but with yellow markings showing in some specimens; wings with macrotrichia more evenly distributed.

Holotype male in the British Museum.

Distribution. SudAn : $4 \hat{\delta}$, Rumbek, vi-vii.I954 (E. T. M. Reid). Nigeria : I2 ô, Kankiya, xii.I956-i.I957 (B. McMillan). French West Africa, Haute Volta : I ô, nr. Bobo Dioulasso, I.I957 (J. Hamon). UGANDA: holotype male and paratype, Lake Victoria. Kenya : paratypes, Kitui. Belgian Congo : paratypes, Lake Kivu.

\section{Tanytarsus (Tanytarsus) spadiceonotatus sp. n.}

Green with brown thoracic and abdominal markings, A.R. I.2, L.R. 2, both combs with spurs, macrotrichia reduced. Easily distinguished from aterrimus and nigrocinctus which have a somewhat similar hypopygium, by the smaller size and different colour.

Male. Wing length $\mathrm{I} \cdot 5 \mathrm{~mm}$.

Head yellow, mouthparts and antennae brown, A.R. I·2, frontal tubercles present but small. Thorax yellowish green, postnotum, sternopleuron and stripes, especially lateral ones, brown. Legs yellowish, apices of femora obscurely darkened, pulvilli and tarsal beard absent, L.R. 2, each tibial comb with a spur. Wings with a few macrotrichia at extreme apices of cells $R_{5}$ and $M_{2}$ and as a single line half-way along former; halteres green. Abdomen yellowish green or green, each segment with a pale brown ring on apical quarter or third, darker centrally and sometimes appearing as a row of spots. Hypopygium (Text-fig. II, $d$ ) not unlike nigrocinctus but appendage I squarer; anal point with a well-formed row of dots, appendage $\mathrm{I} a$ very short, $2 a$ with a brush at apex.

Female resembles male in colour and pattern, macrotrichia evenly distributed over apical half of wing and as a row in basal cell and around margin of anal cell ; antennae with 6 segments.

Holotype male and I5 $\delta^{\star}, 2$ o paratypes Nigeria: Kankiya, xii.I956-i.I957 (B. McMillan); I + paratype, Bauchi Prov., Vom, iii.I957 (W. A. McDonald). S. Rhodesia : 3 ơ paratypes, Salisbury, iv.I956 (E. T. M. Reid).

\section{Tanytarsus (Tanytarsus) mcmillani sp. $\mathrm{n}$.}

Pale yellow and green, scutal stripes yellowish red, abdominal segments each with a dark band posteriorly and indications of a central median stripe; legs pale, no tarsal beard ; macrotrichia evenly distributed ; male hypopygium not unlike nigrocinctus but dots on anal point smaller and appendage I broader. This species is very similar to nigrocinctus in structure but can be distinguished by its much paler colour, absence of tarsal beard, denser wing macrotrichia and male hypopygial details.

Male. Wing length $\mathrm{I} \cdot 8-2 \cdot 0 \mathrm{~mm}$.

Head yellow, mouthparts and antennae pale brown, A.R. I.8, frontal tubercles present. Thorax pale yellow with yellowish red stripes and sternopleuron, the ENTOM. 6, II, 
postnotum is brown. Legs pale, apices of femora and tibiae faintly darker, L.R. 3 or over, tarsal beard absent, each comb of posterior tibia with a well-formed spur. Wings with moderately dense macrotrichia over most of surface, basal quarter bare, halteres pale. Abdomen green, each segment with posterior quarter or third dark ; on segments $2-5$ this band tends to be extended forwards forming a partial median dark line. Hypopygium (Text-fig. II, e) not unlike nigrocinctus; anal point with row of about four dots but these are smaller than in nigrocinctus, appendage I broader, I $a$ short, $2 a$ rather similar in the two species.

Females taken at the same time as the males show a general resemblance but lack the dark abdominal markings.

Holotype male and I9 male paratypes Nigeria: Kankiya, xii.I956-i.I957

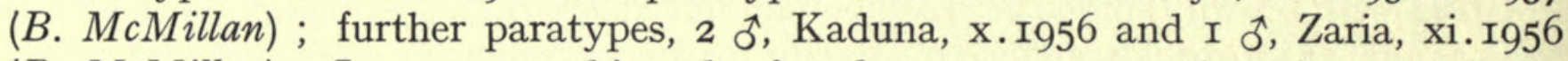
(B. McMillan). I am not making the females paratypes as there is some doubt over their identity; all specimens are in the British Museum.

\section{Tanytarsus (Tanytarsus) flexistilus sp. n.}

Very similar to momillani, differing in colour only in the abdomen which lacks dark markings and is plain green. Structurally, the two species can be separated only by the male hypopygium which in the present species (Text-fig. II, $f$ ) has a narrower anal point of different appearance with the dots reduced to about 2-3, appendage I concave inwardly, I $a$ longer, $2 a$ rather larger than momillani, styles stout and curved. Female not known. This is possibly a well-marked colour variation of momillani-see also the next species.

Holotype male and paratypes 20 , NIGERIA: Kankiya, xii.I956-i.I957 ( $B$. McMillan) in the British Museum. Further paratypes $2 \delta$, French West AFrica, Haute Volta: Sosogona, nr. Bobo Dioulasso i.I957 (J. Hamon) returned to Office de la Recherche Scientifique Outre-Mer.

\section{Tanytarsus (Tanytarsus) zariae sp. $\mathrm{n}$.}

This is another species resembling momillani in structure but differing in the plain green abdomen; it is smaller and paler than either momillani or flexistilus the anal point is more like that of the former but appendages I and I $a$ are more like those of the latter. It may also be a variety of momillani.

Male. Wing length $\mathrm{I} \cdot 5 \mathrm{~mm}$.

Head mouthparts and antennae including pedicel yellowish white frontal tubercles present, A.R. I.2. Thorax yellowish white, stripes barely indicated, these and postnotum yellowish. Legs pale greenish white, pulvilli and tarsal beard absent, L.R. 3, each comb with a spur. Wings fairly evenly clothed with macrotrichia except for basal quarter, halteres greenish. Abdomen pale green; hypopygium (Text-fig. II, g) very similar to momillani but appendage I of more irregular shape, I $a$ longer, styles wider.

Female not known.

Holotype male and 4 ๙ paratypes, Nigeria: Zaria, xi.I956 (B. McMillan); 


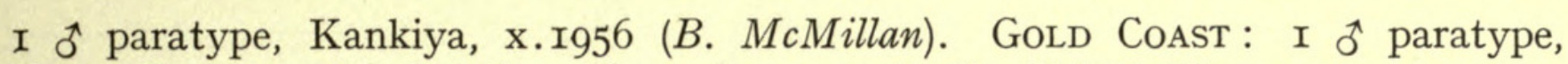
Nangodi, x.I954 (G. Crisp). All specimens are in the British Museum.

\section{Tanytarsus (Tanytarsus) trifidus $\mathrm{sp} . \mathrm{n}$.}

Thoracic markings brown, abdomen plain green, frontal tubercles probably absent, L.R. 3, macrotrichia dense at apex, sparser elsewhere ; most easily distinguished from species with somewhat similar colouring such as spadiceonotatus by the peculiar appendage $2 a$ which is in three branches, each bifid and pointing anteriorly instead of posteriorly.

Male. Wing length $\mathrm{I} \cdot \mathrm{O}-\mathrm{I} \cdot 4 \mathrm{~mm}$.

Head and mouthparts yellowish, antennae darker, A.R. I, frontal tubercles cannot be seen and are probably absent. Thorax yellowish green with stripes and postnotum brown. Legs very pale and without markings; L.R. 3, pulvilli and tarsal beard absent, both combs of posterior tibia with spurs. Wings with $\mathrm{R}_{4+5}$ ending at level of apex of $\mathrm{M}_{3+4}$, macrotrichia dense at apex, but sparser and confined to tracts along centre of cells more basally, halteres green. Abdomen pale green or whitish, without dark markings. Hypopygium (Text-fig. II, $h$ ) with row of about four large dots on anal point; appendage I subovoid, sometimes with inner margin slightly produced, I $a$ sinuous, well developed, $2 a$ quite characteristic, pointing anteriorly and formed of three bifid branches which are sometimes folded up and difficult to distinguish from each other.

Female not known.

Holotype male and I5 $\delta^{\star}$ paratypes, Nigeria : Kankiya, xii.I956-i.I957 and I o paratype, Zaria, xi.r956 (B. McMillan) all in the British Museum. Further paratype I d, French West Africa, Haute Volta: Banouaradougou, nr. Bobo Dioulasso, ix.r956 (J. Hamon) returned to Office de la Recherche Scientifique Outre-Mer.

\section{Tanytarsus van DER WUlP SUBgenus Calopsectra Kieffer}

Calopsectra Kieffer, 1909, Bull. Soc. Hist. nat. Metz, $26: 50$.

Tanytarsus subg. Tanytarsus Group B Edwards, I929, Trans. ent. Soc. Lond. 77 : 4I I.

Tanytarsus subg. Calopsectra Goetghebuer, 1938, in Lindner, Flieg. Pal. Reg. 3 (13c) : I27;

Brundin, 1947, Arkiv Zool. 39A no. 3:66 (mis-spelt Calospectra).

This subgenus is separated from the others by the presence of well-developed pulvilli. In the two African species and in two Palaearctic species the anal point of the male carries a pair of reflexed appendages which are hinged either near the tip or at the base of the anal point and lie between two narrow ridges or flaps on the IXth tergite. T. (C.) subreflexens Freeman is only doubtfully distinct from the Palaearctic species richmondensis Edwards.

Key to African Species of Tanytarsus subg. Calopsectra

Abdomen quite unmarked, anal point of male long, its appendages hinged near its apex (Text-figs. 12, $a, b$ )

subreflexens Freeman

Abdomen with dark rings or mainly dark, anal point short, its appeadages hinged near its base (Text-figs. I2, $d, e)$. , , , , nigricornis Goetghebuer 


\section{Tanytarsus (Calopsectra) subreflexens Freeman}

Tanytarsus (Calopsectra) subreflexens Freeman, 1955, Explor. Parc Nat. Albert, Miss. de Witte, fasc. 83 : 37 .

A yellowish green species, structurally very similar to the Palaearctic species reflexens and richmondensis Edwards. Pulvilli present, L.R. 3, anal point of male with reflexed appendages hinged near apex and fitting between two short ridges or flaps on the IXth tegite quite as in richmondensis. Separable from the following
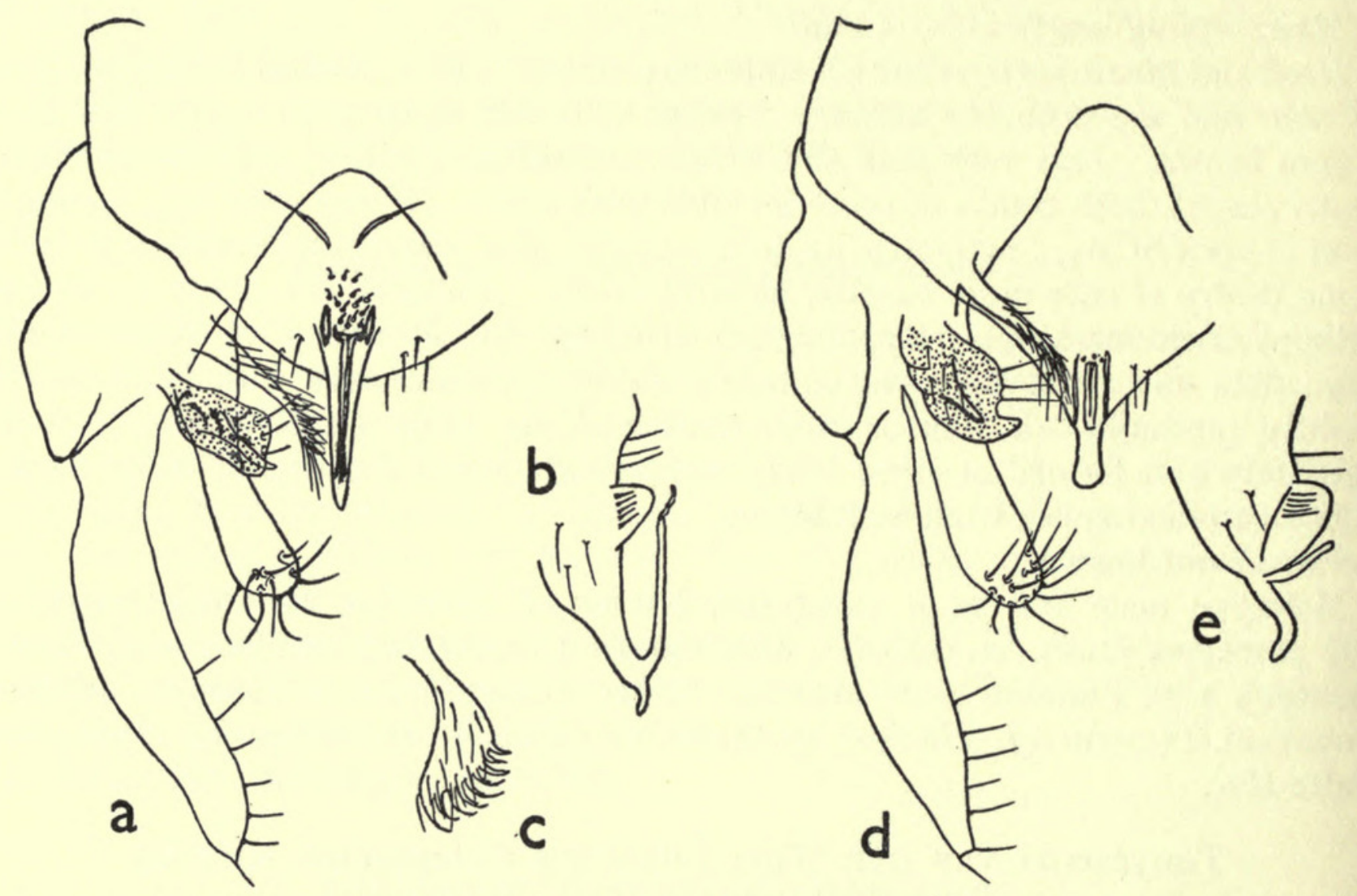

Fig. I2. Male hypopygia of Tanytarsus (Calopsectra). (a)-(c) C. subreflexens. (a) In dorsal aspect; (b) anal point in lateral aspect; (c) appendage $2 a$ in lateral aspect ; (d)-(e) T. nigricornis. (d) In dorsal aspect; (e) anal point in lateral aspect.

species by the pale colour and longer anal point. Whether this species is really distinct from richmondensis is open to some doubt, but as it is so pale, the leg ratio is greater and a name is available I have preferred to maintain the separation.

Male. Wing length $\mathrm{I} \cdot 5-2 \cdot 5 \mathrm{~mm}$.

Head yellowish, in some specimens slightly brownish, mouthparts and antennae may also be brown, frontal tubercles present, A.R. I·3. Thorax yellow, scutal stripes hardly darker. Legs yellow, pulvilli present, L.R. 3, posterior tibial combs with two spurs, outer one long, inner one short. Wings covered all over with macrotrichia, halteres yellow. Abdomen pale green; hypopygium (Text-figs. I2, $a-c$ ) indistinguishable from richmondensis; anal point long and with a pair of reflexed 
appendages hinged nears its apex and fitting between a pair of short flaps between which are some short hairs ; appendage I rectangular in outline and hairy, sometimes slightly produced at the outer apex, I $a$ hardly longer ; $2 a$ broad and with broad curved tooth-like hairs along margin, appendage is usually seen edge-on in dorsal view ; styles slightly sinuous at apex.

Female resembles male in colour, antennae with last 2 segments indistinctly separated.

Holotype male in Institut Royal des Sciences Naturelles de Belgique.

Distribution. Belgian Congo: type series from Lac Magera, Kamande, Vitshumbi (Parc Nat. Albert). Nigeria: I3 ô, Kankiya, xii.I956-i.I957 ( $B$. McMillan). Gold Coast: I $\hat{\jmath}$, I , , Nangodi, x.I954 (G. Crisp). Abyssinia : I ô, I , , Waldia, ii. I936 (J.W.S. Macfie).

\section{Tanytarsus (Calopsectra) nigricornis Goetghebuer}

Tanytarsus nigricornis Goetghebuer, 1935, Rev. Zool. Bot. Afr. 26 : 398.

This is normally a darker species than subreflexens, and usually has brown thoracic markings and abdominal bands but pale specimens do occur; L.R. $2 \cdot 5$, frontal tubercles present; male hypopygium with short anal point, reflexed appendages shorter than in nigricornis and hinged nearer the base of the anal point, lobes between which they lie are longer. I have seen Goetghebuer's type and found it to be very pale but the male hypopygium is identical with that described here.

Male. Wing length $\mathrm{I} \cdot 5-2 \cdot 0 \mathrm{~mm}$.

Head green, antennae and mouthparts brown or blackish, A.R. I.75, frontal tubercles present. Thorax pale green; stripes, postnotum and sternopleuron usually brown or blackish, reddish in pale specimens. Legs brown, pulvilli present, L.R. $2 \cdot 5$, spurs as in subreflexens. Wings with macrotrichia over most of the surface, halteres green. Abdomen in most specimens green with dark markings; the apical half of each segment is usually brown but the brown colour may encroach on the green in the central line, even joining up with the dark on the segment in front, so that the green is reduced to lateral patches on each segment ; occasional specimens, including the holotype, have the abdomen entirely green. Hypopygium (Text-figs. $\mathrm{I} 2, d, e$ ) with shorter and more bent anal point than subreflexens, reflexed appendages hinged near the base of the point, flaps between which they lie are longer in this species and whole side aspect different; appendage I with definite beak, though of variable shape, I $a$ of variable length, $2 a$ as in nigricornis, style not sinuous at apex.

Female similar to male, abdominal bands present but less obvious, antennae with segments 5 and 6 indistinctly separated.

Holotype male in Musée Royal du Congo Belge.

Distribution. Belgian Congo: holotype male, Kamande. Abyssinia : i $\hat{o}$, 2 ㅇ, Waldia, xii.I935 (J.W.S. Macfie). YEMEN : 5 ô, San’a, xi.I937 (C. Rathjens). Uganda: II, ô 3 ㅇ․ L. Victoria, vi.I950 (W. W. Macdonald). S. Rhodesia :

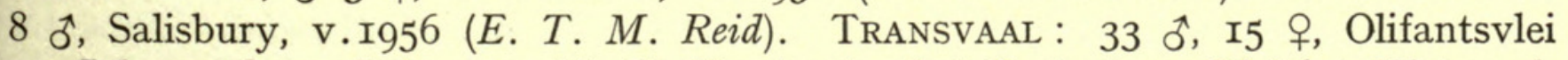
nr. Johannesburg, ii-ix.I954 (A. D. Harrison) ; 6 ô, Lydenburg District, Waterval, 


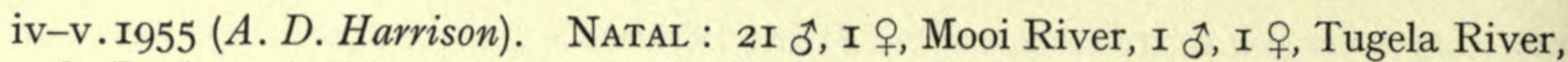
I ㅇ, Bushman's River, ix. I953 (A. D. Harrison); 2 б., I 우, Weenen, viii.I924 (H. P. Thomasset).

\section{Tanytarsus VAN DER WULP SUBgenUS Rheotanytarsus BAUSE}

Rheotanytarsus Bause, I9I4, Arch. Hydrobiol. Planktonk., Suppl. 2 (I) : I 20.

Tanytarsus subg. Tanytarsus Group C Edwards, 1929, Trans. ent. Soc. Lond. $77: 4 \mathrm{I} 3$.

Tanytarsus subg. Rheotanytarsus Goetghebuer, 1938, in Lindner, Flieg. Pal. Reg. 3 (13c) : I32 ; Brundin, 1947, Arkiv Zool. 39A no. $3: 76$.

This subgenus is mainly to be separated from the others by the sharp narrowing of the apex, sometimes of the apical third, of the male styles, although occasionally it is less marked than usual. In addition pulvilli and frontal tubercles are absent and $R_{2+3}$ is obliterated by the close approximation of $R_{1}$ and $R_{4+5}$. The larvae of the European species T. photophilus Goetghebuer make tube-like cases and Dr. K. M. F. Scott tells me in litt. that T. fuscus makes similar cases in South Africa.

\section{Key to African Species of Tanytarsus subgenus Rheotanytarsus}

General colour pale yellowish green, A.R. I, L.R. nearly 3, male styles (Text-fig. I3, a) sharply contracted for apical third and bent downwards at tips. . guineensis Kieffer General colour of most specimens brown, A.R. o.6, L.R. hardly 2, male styles (Textfig. I3,b) much less sharply contracted and not for as much as apical third, nor bent down at tips

\section{Tanytarsus (Rheotanytarsus) guineensis Kieffer}

Rheotanytarsus guineensis Kieffer, I918, Ann. Mus. nat. Hung. 16 : 73.

Yellowish green, thoracic stripes reddish; A.R. about I, L.R. nearly 3, male styles strongly contracted for apical third and bent downwards at tips. Distinguished from $T$. fuscus as shown in the key.

Male. Wing length $\mathrm{r} \cdot 8 \mathrm{~mm}$.

Head, antennae and mouthparts yellow, A.R. about I, frontal tubercles absent. Thorax yellowish green, stripes, postnotum and sternopleuron reddish. Legs yellowish, pulvilli and tarsal beard absent, L.R. 2·75. Wings with reduced anal lobe, fairly densely clothed all over with macrotrichia except on the basal quarter. Abdomen uniformly pale green; hypopygium (Text-fig. I3, a) with anal point of variable length, sometimes a little longer than figured, appendage I more or less oval, very similar to fuscus, appendage I $a$ absent, 2 rather clubbed, $2 a$ hairy and with oval lamellae at the apex; styles highly characteristic, the narrow portion being long and bent downwards at the apex.

Female similar to the male, antennae with 6 segments.

The type series is lost, but the figure of the male hypopygium given by Kieffer makes identification certain. Type locality Guinée FrançAIs : Mamon.

Distribution. Uganda: 2 $\delta$, I + , L. Victoria $(W . W$. Macdonald $)$. Belgian Congo : I ô, Rutshuru, i. I934 (de Wulf) ; 2 ô, Elisabethville, xii. I938 (H. J. Brédo). 


\section{Tanytarsus (Rheotanytarsus) fuscus Freeman}

Tanytarsus (Rheotanytarsus) fuscus Freeman, 1954, Proc. R. ent. Soc. Lond. (B) 23 : 25 ; Freeman, 1955, S. Afr. Animal Life. Uppsala, 2:38r.

Usually a brown species, although some specimens from S. Rhodesia are coloured like guineensis (see below), wings densely hairy; A.R. 0.6, L.R. hardly 2, male styles slightly contracted at apex, anal point well formed but narrower than in guineensis. Distinguished from guineensis by its normally darker colour, lower A.R. and L.R. and by the much shorter apical narrow portion of the styles which is sometimes hardly apparent.
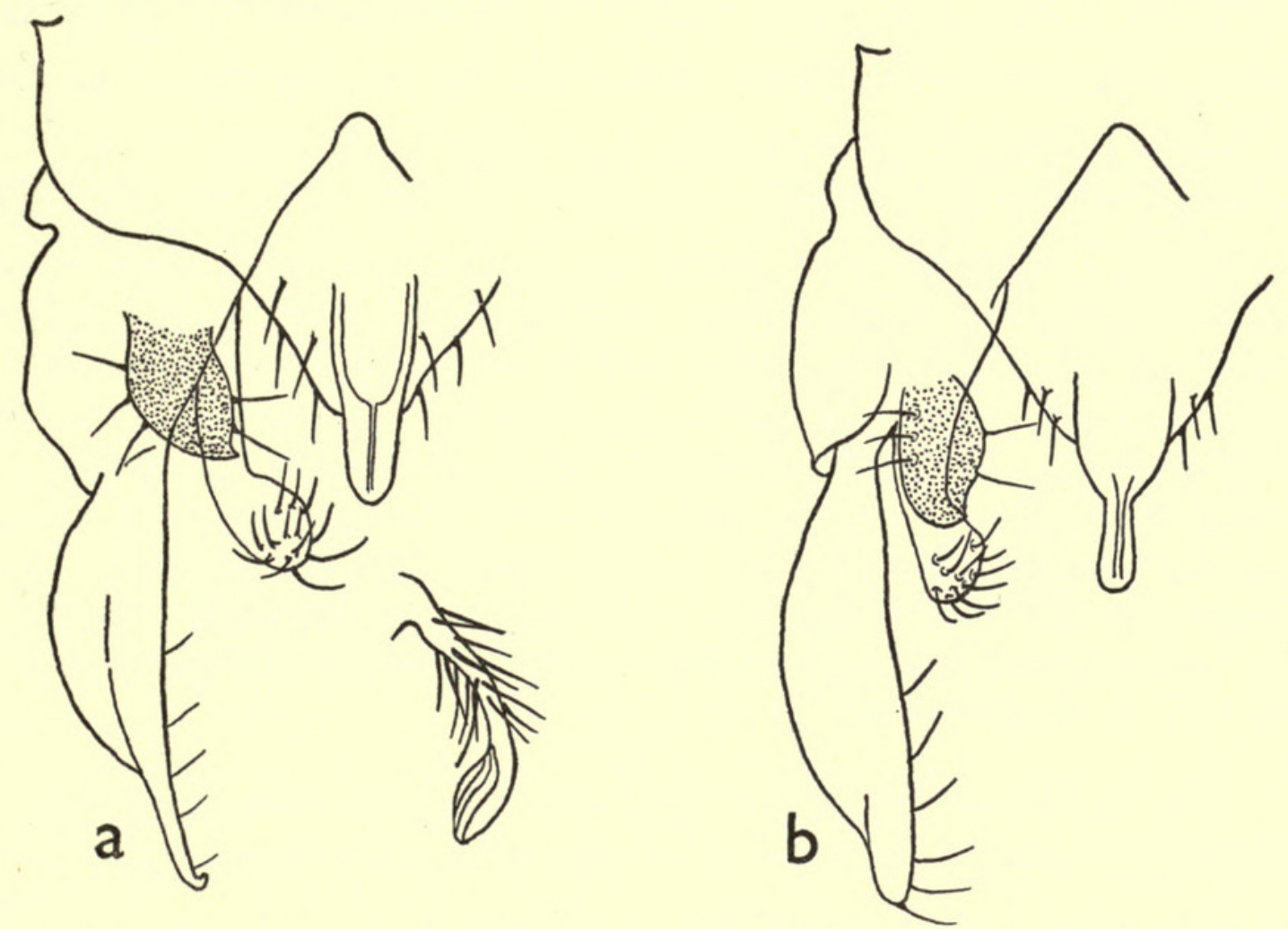

Fig. I3. Male hypopygia of Tanytarsus (Rheotanytarsus). (a) T. guineensis with appendage $2 a$ shown separately; (b) $T$. fuscus with appendage $2 a$ omitted.

Male. Wing length $\mathrm{I} \cdot 5-2 \cdot 0 \mathrm{~mm}$.

Head, mouthparts and antennae brown; A.R. 0.6, frontal tubercles absent. Thorax brown or yellowish brown; stripes, postnotum and sternopleuron darker brown. Legs brown, L.R. 2 or slightly less, no tarsal beard. Wings with reduced anal lobe, thickly clothed over most of the surface with macrotrichia, halteres pale. Abdomen brown; hypopygium (Text-fig. I3, b) with well-developed anal point which is narrower than in guineensis; appendage I not dissimilar, I $a$ absent, $2 a$ similar ; styles of most specimens contracted at apex as shown, but not turned down at tips, sometimes with the contraction less obvious.

Female similar to male, abdomen may be tinged with green, antennae with 6 segments.

Holotype male in the British Museum, type locality CAPE Province: Berg River, Wellington. 
Distribution. CAPE Province: type series and other specimens from Berg River at Wellington, Piquetberg and French Hoek, also from Wemmer River and Palmiet River. NAtal: 5 ô, I क, Shooter's Hill, vii.I956 (B. Stuckenberg). Uganda: I ô, Mt. Elgon, Bulambuli, 9,500 ft., viii.I934 (J. Ford). Abyssinia : I đa, 6 ㅇ, Waldia, i.I936 (J. W. S. Macfie). A series from Rhodesia (3 ô, 2 ㅇ, Salisbury, v.I956, E.T.M. Reid) is coloured green with yellowish-red thoracic markings as in guineensis. Structurally, they are similar to other specimens of fuscus and I am treating them as a colour variety.

\section{Tanytarsus van DER WUlP Subgenus Cladotanytarsus KiefFer}

Cladotanytarsus Kieffer, 1922, Ann. Soc. sci. Brux. Mém. 42 : 100; Brundin, 1947, Arkiv Zool. 39A no. $3: 78$.

Tanytarsus subg. Tanytarsus Group F Edwards, 1929, Trans. ent. Soc. Lond. 77 : 418.

Tanytarsus subg. Cladotanytarsus Goetghebuer, 1938, in Lindner, Flieg. Pal. Reg. 3 (13c) : 133.

Very similar to Tanytarsus s. str., separated by the presence of branched hairs on appendage $2 a$ of the male hypopygium; pulvilli absent, male styles short and not contracted at the tips. The five African species belonging to this group that I have been able to recognize, are not all easy to separate because there seems to be a good deal of intergrading. Although a large dark male of capensis at first sight appears very different from a small pale specimen of reductus, there are so many intergrading forms and varieties that the definition of each species becomes blurred.

$T$. fulvofasciatus Kieffer belongs here but it cannot be definitely assigned to any one species because the colour and pattern fit lewisi, whilst the male genital structure agrees better with pseudomancus.

\section{Key to African Species of Tanytarsus Subgenus Cladotanytarsus}

I. Anterior tarsi of male with long beard, a large dark species (wing length $\mathrm{I} \cdot 7-2 \cdot 3 \mathrm{~mm}$.)

Tarsal beard absent

capensis Freeman

2. Abdomen with dark markings .

Abdomen plain and unmarked .

3. Thoracic markings dark brown or blackish, appendage I smaller, $2 a$ less bushy

(Text-fig. I4, $a)$. . . . . . . . pseudomancus Goetghebuer Thoracic markings reddish, appendage I larger, $2 a$ bushy (Text-fig. I4, $c$ )

lewisi Freeman

4. Wing of male with macrotrichia on fork and anal veins, thoracic markings black, appendage I large (Text-fig. I4, $e$ ).

- linearis Freeman

Wing veins of male lacking these macrotrichia, thoracic markings reddish or brown, appendage I small (Text-fig. I4, $d$ )

. reductus Freeman

\section{Tanytarsus (Cladotanytarsus) pseudomancus Goetghebuer}

Tanytarsus pseudomancus Goetghebuer, 1934, Rev. Zool. Bot. Afr. 25 : 200.

Tanytarsus (Cladotanytarsus) pseudomancus Freeman, 1955, Explor. Parc Nat. Albert, Miss. de Witte, fasc. 83: 38 ; Freeman, 1955, S. Afr. Animal Life. Uppsala, $2: 38$ I.

Thoracic stripes dark brown, wings with macrotrichia at apex, L.R. $2 \cdot 5$, abdomen whitish or pale green, each segment with a dark apical band, also darker along 
median line, anal point fairly broad and with numerous dots, appendage I $a$ sinuous. Apart from a dark form found in the Cape, this species can be distinguished from the others by the colour pattern of the abdomen; the shapes of appendages I and $\mathrm{I} a$ are also distinctive.

The hypopygial structure is similar to that figured by Kieffer for Cladotanytarsus fulvofasciatus which also has dark rings on the abdomen, but the pale colour of the thorax of Kieffer's species is not like any that I have seen and I prefer not to synonymize the two, especially as Kieffer omitted the anal point in his figure.

Male. Wing length $\mathrm{I} \cdot 3-\mathrm{I} \cdot 5 \mathrm{~mm}$.

Head and mouthparts brown, pedicel dark brown, A.R. I.2, frontal tubercles not visible. Thorax with yellowish background; stripes, postnotum and sternopleuron dark brown or blackish. Legs unmarked, yellowish or brown, L.R. about 2.5 or slightly less, tarsal beard absent, pulvilli absent, posterior tibia with a spur on each comb. Wings with macrotrichia reduced to a small number at extreme apices of cells $R_{5}$ and $M_{2}$ and a short row down the centre of the apical half or less of cell $R_{5}$, veins of posterior fork and anal vein without macrotrichia. Halteres pale. Abdomen usually whitish or pale green or yellowish, segments I-6 with an apical dark ring; abdomen also with an ill-defined central dark line, dividing pale area of each segment. Hypopygium (Text-fig. I4, a) with broad anal point marked with as many as 20 dots, appendage I narrow but well formed, I $a$ long and sinuous, $2 a$ showing a good deal of subdivision but not as bushy as in lereisi.

Female. Such specimens as I have seen, have the macrotrichia more numerous in apical half of wing and around anal cell ; all veins hairy, abdomen dark.

I have seen the type series of males in Musée Royal du Congo Belge, Tervuren.

Distribution. Egypt: 7 ô, Darfur, El Fasher, iv. I920 (H. Lynes) ; 3 ô, Aswan, i.I923 (S. Hirst). Sudan: I5 స̂, Khartoum, i.I93I (H. W. Bedford); I8 $\widehat{0}$. Wad Medani, ii.I952 (D. J. Lewis). Nigeria: 9 ô. Kankiya, xii.I956i.I957 (B. McMillan). Gold CoAst: I ô, nr. Kumasi, x.I952 (J. Bowden). Belgian Congo: type series and other specimens, Kivu; long series from Parc National Albert. TransvaAl: 3 ô, Marble Hall, iv-v.r955 (A. D. Harrison). Cape Province: I ô, Berg River, Piquetberg, i.I953 (K. M. F. Scott). Some specimens from CAPE PROviNCE : Kirstenbosch, are structually very similar but have the abdomen much darker and the wings more hairy. They may suggest a link with capensis.

\section{Tanytarsus (Cladotanytarsus) capensis Freeman}

Tanytarsus (Cladotanytarsus) capensis Freeman, 1954, Proc. R. ent. Soc. Lond (B) $23: 24$.

This species is very similar to pseudomancus and may only be a dark variety of it. It is larger, with wing length $\mathrm{I} \cdot 75-2 \cdot 3 \mathrm{~mm}$., and the colouring is darker, the abdomen being mainly very dark brown or blackish, although if a male is examined from behind the pale areas present on the abdomen of pseudomancus can just be distinguished. It is most easily distinguished by the well-developed long beard on the front tarsi of the male. Hypopygium (Text-fig. I4, $b$ ) quite similar to pseudomancus 
but the anal point is narrower, appendage I more strongly waisted and I $a$ less sinuous.

Holotype male in the British Museum.

Distribution. Known only from CAPE Province: holotype and paratypes, Zeekoe Vlei ; paratypes, Bergvliet and Piquetberg.

\section{Tanytarsus (Cladotanytarsus) lewisi Freeman}

Tanytarsus (Cladotanytarsus) lewisi Freeman, 1950, Proc. R. ent. Soc. Lond. (B) 19: 58 ; Lewis, 1957, Bull. ent. Res. 48 : I55-184.

A pale green species, thoracic markings reddish, abdomen with dark bands, frontal tubercles present in the male, anal point narrow, appendage I large, I $a$ bent at apex, $2 a$ large and bushy. The larger appendage I and the more bushy appendage $2 a$ make this species comparatively easy to determine, they also suggest that this is not the species which Kieffer described as fulvofasciatus even though the colouring is similar.

Male. Wing length $\mathrm{I} \cdot 5-\mathrm{I} \cdot 75 \mathrm{~mm}$.

Head yellowish green, frontal tubercles small but distinct, A.R. about I. Thorax pale yellowish green, mesonotal stripes, postnotum and sternopleuron reddish. Legs pale green, tibiae may be darkened at apices, tarsal beard and pulvilli absent, combs of posterior tibia each with a spur, L.R. 2.25. Wings with macrotrichia on membrane at extreme apex, mostly in cell $R_{5}$, fork veins and anal vein bare; halteres pale. Abdomen green, each segment dark at apex giving a ringed appearance; hypopygium (Text-fig. I4, c) differs from other species by the larger appendage I and the more bushy and stouter $2 a$; $\mathrm{I} a$ is bent at apex, anal point narrow and with a few dots basally, IXth tergite with a prominent central ridge which is indicated by two parallel lines in the figure.

Female differs from male in colour by the abdominal rings being dark green; wings with a few extra macrotrichia as lines down the centres of the cells, fork veins bare.

Holotype male in the British Museum.

Distribution. Known only from SudAn: Khartoum (type locality), Wad Medani and Wadi Halfa.

Lewis (I957) records this species as a great nuisance and as causing a form of asthma in Khartoum where it is extremely abundant; he gives some account of the biology and life history in the same paper.

\section{Tanytarsus (Cladotanytarsus) reductus Freeman}

Tanytarsus (Cladotanytarsus) reductus Freeman, 1954, Proc. R. ent. Soc. Lond. (B) 23 : 180.

A small green species with reddish or brown thoracic markings and plain abdomen ; macrotrichia reduced but present for about half length of vein $\mathrm{M}_{1}$, tarsal beard absent; hypopygium with narrow anal point, small appendage I and straight $\mathrm{I} a$.

Male. Wing length $\mathrm{I} \cdot 25-\mathrm{I} \cdot 5 \mathrm{~mm}$. 
Head, mouthparts and antennae yellow or brown, small frontal tubercles visible in some specimens, A.R. about 0.75. Thorax yellow; stripes, postnotum and sternopleuron either reddish yellow or brown. Legs yellow or greenish, L.R. 2*4,

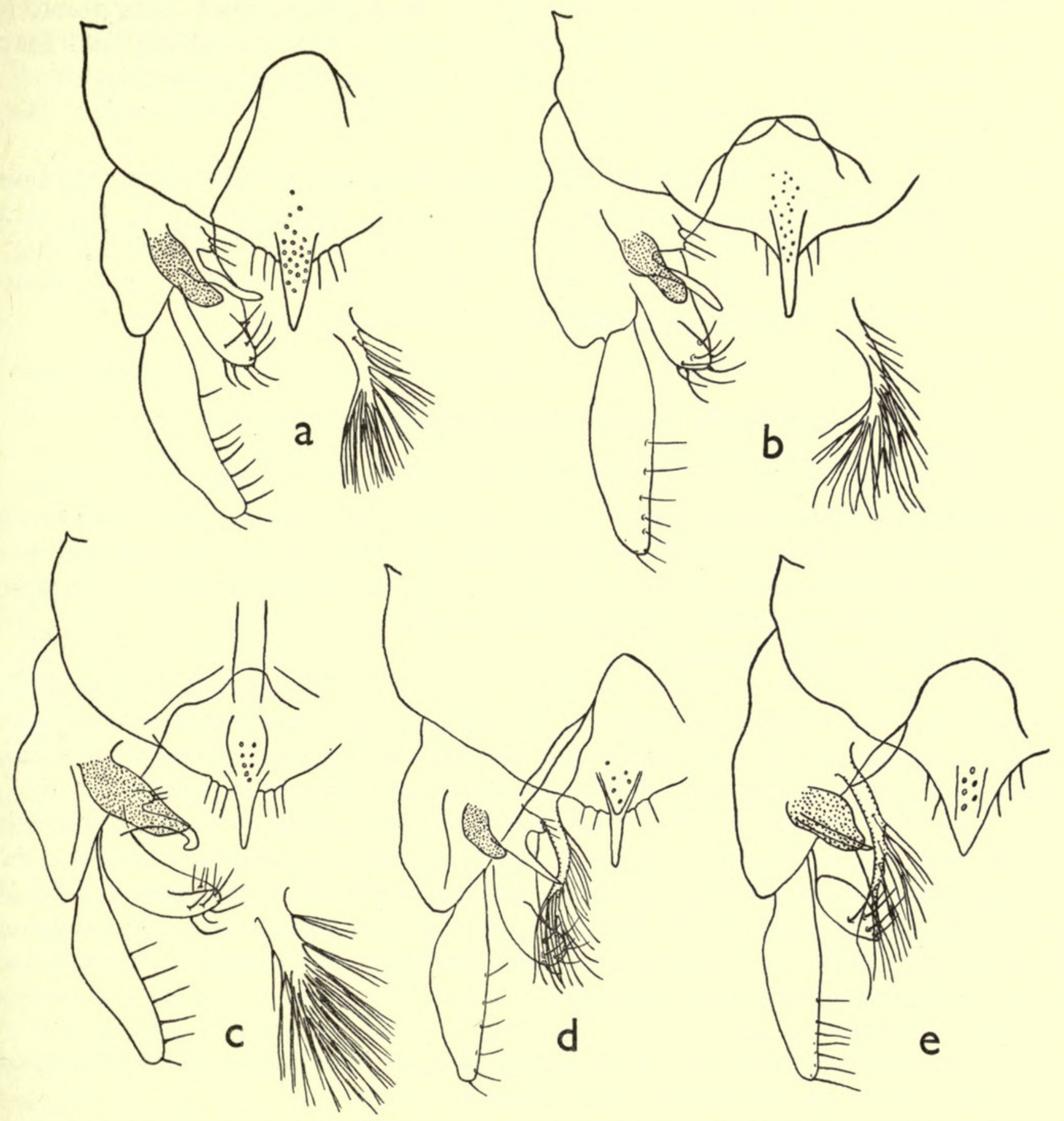

FIG. I4. Male hypopygia of Tanytarsus (Cladotanytarsus). (a) T. pseudomancus with appendage $2 a$ drawn separately; (b) $T$. capensis with appendage $2 a$ drawn separately; (c) $T$. lewisi with appendage $2 a$ drawn separately; (d) $T$. reductus; (e) $T$. linearis.

beard and pulvilli absent, both combs of posterior tibia spurred. Wings with posterior fork rather more distal than usual, macrotrichia present at extreme apices of cells $R_{5}$ and $M_{2}$ and as lines down the centre of one or both cells, vein $M_{1}$ with macrotrichia for about half its length; halteres pale. Abdomen green and without 
darker markings ; hypopygium (Text-fig. $\mathrm{I}_{4}, d$ ) with narrow anal point with about six dots at its base; appendage I small and reduced, I $a$ long by comparison and straight, $2 a$ with fewer hairs than in some species.

Female resembles male but wings more hairy; macrotrichia reach back nearly to base of cell $R_{5}$, there is a short line in cell $M_{1}$, posterior fork is bordered anteriorly, there is a small patch in fork cell ; veins $\mathrm{M}_{4}, \mathrm{Cu}$ and An with macrotrichia.

Holotype male in the British Museum, type locality CAPE Province: Berg River, Piquetberg.

Distribution. Cape Province : series from Berg River, Piquetberg, Hermon, Cecilia's Drift, Wellington. Belgian Congo: 2 s, Kiavinionge (N. lac Ed.), iii.I953 (J. Verbeke); I ô, Kasenyi (L. Albert), vii.I953 (J. Verbeke). SudAN : 3 ô. Amadi, vi-vii.I954 (E. T. M. Reid). French West Africa: I ô, Haute Volta, nr. Banfora, xii.I956 (J. Hamon).

\section{Tanytarsus (Cladotanytarsus) linearis Freeman}

Tanytarsus (Cladotanytarsus) linearis Freeman, 1954, Proc. R. ent. Soc. Lond. (B) 23 : 180.

A small dark green species, stripes black, abdomen unmarked, wings with rather more macrotrichia than usual in the male, they are also present on fork and anal veins; hypopygium differs from other species by the wide triangular anal point and broad appendage I which has $\mathrm{I} a$ hardly longer.

Male. Wing length $\mathrm{I} \cdot 2 \mathrm{~mm}$.

Head, antennae and mouthparts black, A.R. 0.75. Thorax with dark green background ; stripes black and more or less separate, postnotum and sternopleuron black. Legs pale brown, L.R. about $\mathrm{I} \cdot 8$, tarsal beard absent. Wings with macrotrichia present as patches at apices of cells $R_{5}, M_{2}$ and $M_{4}$ and as lines in centres of cells $R_{5}$ (to the base) and $M_{2}$ (for half length of vein $M_{1}$ ), along each side of posterior fork veins nearly to wing base and as a line along An; in addition there is a line of macrotrichia just inside the posterior margin ; posterior fringe rather long, veins $\mathrm{M}$, $\mathrm{Cu}$ and $\mathrm{An}$ with macrotrichia. Halteres pale. Abdomen dark green; hypopygium (Text-fig. I4, e) with anal point broad and triangular, appendage I fairly broad, I $a$ hardly longer, $2 a$ with long sparse hairs.

Female not known.

Holotype male and paratypes in the British Museum (type locality CAPE ProvincE: Platteklip Gorge), no further material is known.

\section{Genus STEMPELLINA Bause}

Stempellina Bause, 1914, Arch. Hydrobiol. Suppl. 2 : 120; Goetghebuer, 1938, in Lindner, Flieg. Pal. Reg. 3 (13c) : 96.

Tanytarsus subg. Stempellina Edwards, I929, Trans. ent. Soc. Lond. 77 : 419.

Eyes bare, male antenna with only II distinct segments, small frontal tubercles present, scutellum with only two long bristles which are placed close together at the apex, tibial combs small and separate, only one armed with a slender spur, wings 
cuneiform and lacking anal angle, fringe long, $\mathrm{R}_{4+5}$ ending before or above tip of $\mathrm{M}_{3+4}$.

The species in this genus are all small or very small, the Palaearctic ones have larvae with a case-bearing habit similar to that of Zavrelia. The adults may easily be distinguished from Zavrelia by the bare eyes ; they are best separated from Tanytarsus by the wing shape and venation.

\section{Key to African Species of Stempellina}

L.R. $2 \cdot 4-2 \cdot 8$, appendage $2 a$ of male long and narrow (Text-fig. $15, a$ )

chambiensis Goetghebuer
L.R. I.5, appendage $2 a$ of male shorter and truncate (Text-fig. $\left.{ }_{5}, b\right)$ truncata sp. $\mathrm{n}$.

\section{Stempellina chambiensis Goetghebuer}

Thienemanniella (sic!) chambiensis Goetghebuer, 1935, Rev. Zool. Bot. Afr. $27: 365$.

As explained in a previous Part of these Studies (Bull. Brit. Mus. (Nat. Hist.) $4: 365$ ), I have examined the type series of both Thienemanniella chambiensis and trivittata Goetghebuer in Musée Royal du Congo Belge. There are six specimens, three under each species, each specimen bearing an author's identification label. Goetghebuer does not mention the female of chambiensis but the specimen marked holotype is in fact a female and the allotype is a male. The third specimen under this species is a female of Thienemanniella trivittata. There is a third specimen of chambiensis (a male) labelled as the holotype of trivittata, a species in which the holotype should be a female.

It is obvious that there has been a good deal of muddle over the labelling of the specimens and I have decided that the three specimens of chambiensis are best treated as cotypes especially as no holotype is mentioned in the description. I have selected a male from Mugunga as the lectotype.

Goetghebuer's description and figure of the wing of chambiensis, with its longer costa and macrotrichia on the membrane, make it clear that the species does not belong to Thienemanniella. It is abundantly clear from the specimens (L.R. 2.4) that they do not even belong to the Corynoneurinae but to the Chironominae. The species is a typical member of the genus Stempellina, falling into Edwards' group $\mathrm{B}$, very similar structurally to the Palaearctic species $S$. minor Edwards but easily separated by the pale coloration, much smaller size (wing length 0.7 against $\mathrm{I} \cdot 3$ ) and greater leg ratio $(2 \cdot 4$ or more against $\mathrm{I} \cdot 6)$. It is a minute insect with dark knees, narrow wings, long wing-fringe and bare eyes ; L.R. $2 \cdot 4-2 \cdot 8$, A.R. only about 0.5 .

Male. Wing length $0.7 \mathrm{~mm}$.

Head pale, very small frontal tubercles present, eyes bare, dorsal narrow portion hardly developed so that eyes almost reniform ; antennae with II segments, segments quite short at base but progressively increasing until tenth is three times as long as wide; eleventh segment three times length of tenth, A.R. 0.5. Thorax greenish white, mesonotal stripes separate; stripes, sternopleuron and postnotum brownish yellow; so far as can be seen scutellum with two bristles only. Legs pale, apices 
of femora and knees darkened, tibial combs small, well separated, only one spur present which is long and curved; L.R. $2 \cdot 4-2 \cdot 8$, pulvilli absent. Wings cuneiform and with long hair fringe ; costa retracted, so that it is just basal to level of tip of $\mathrm{M}_{3+4}$, macrotrichia present at apex and as hair lines in cells $\mathrm{R}_{5}$ and $\mathrm{M}_{2}$. Halteres dark. Abdomen brown; hypopygium (Text-fig. I5, a) very similar to $S$. minor Edwards ; anal point well developed, styles short, appendage I either as shown or rather more oval, I $a$ absent, $2 a$ long, narrow and with simple hairs.

Female very like the male; macrotrichia more numerous and hair lines extend nearer the wing base.

Lectotype male, Belgian Congo: Parc National Albert, Cratère Mugunga, in Musée Royal du Congo Belge.

Distribution. Belgian Congo: lectotype and paratype, Cratère Mugunga; I + , paratype, Escarpement Kabasha, Chambi, x.I933. Sudan : I ô, Amadi, vi-vii.I954 (E. T. M. Reid). TransvaAl: I đ̂, nr. Nelspruit, ix.I954 (A. D. Harrison).
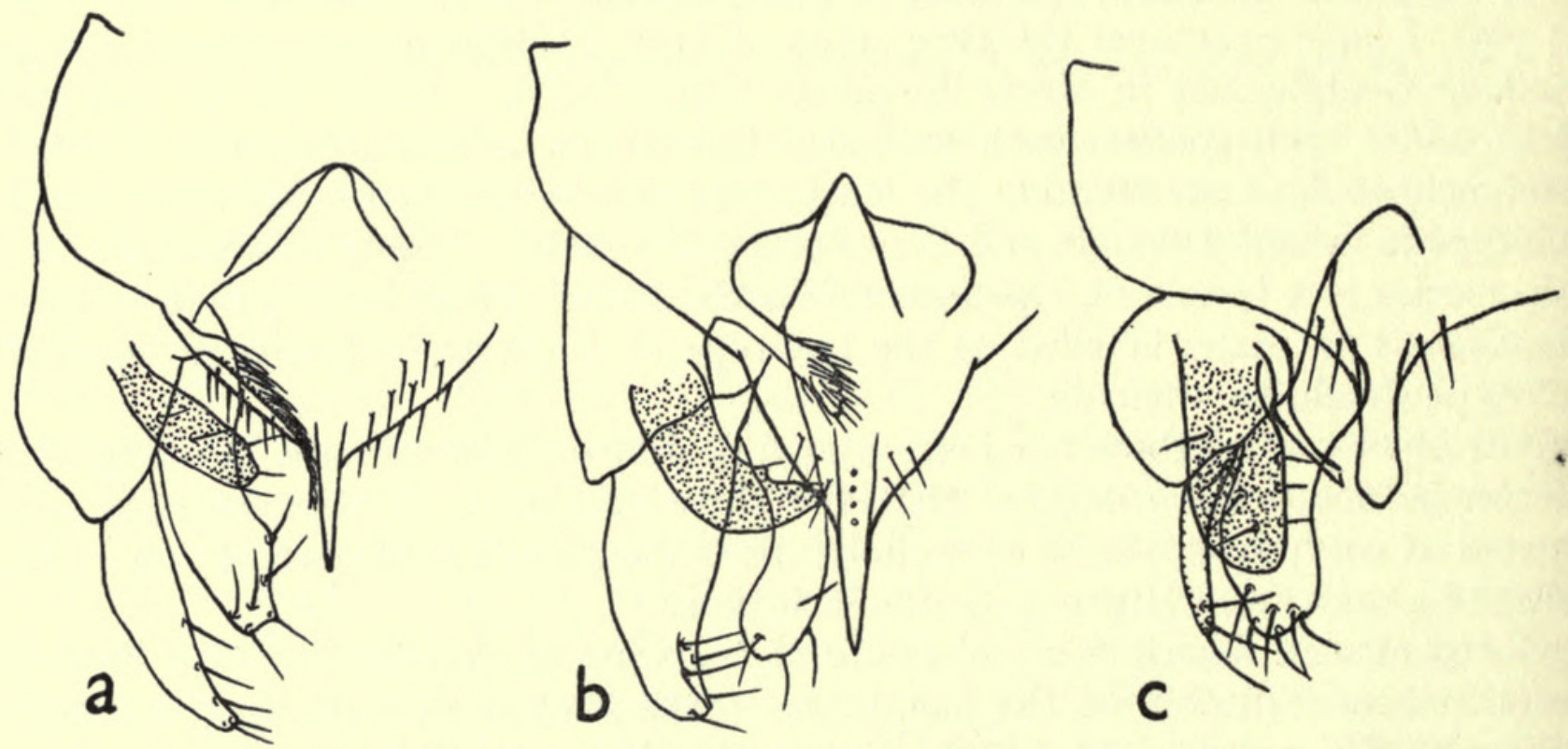

FIG. I5. Male hypopygia of Stempellina and Zavrelia. (a) S. chambiensis;

(b) S. truncata; (c) Z. kribiensis.

\section{Stempellina truncata sp. n.}

Darker than chambiensis and with higher antennal ratio and lower leg ratio, otherwise very similar in appearance; male hypopygium quite different, anal point with row of dots, appendage I curved and larger, appendage $2 a$ short and blunt.

Male. Wing length $\mathrm{r} \cdot 0 \mathrm{~mm}$.

Head brown, small frontal tubercles present, eyes bare and practically reniform, antennae brown, with II segments, A.R. nearly I. Thorax brown, paler on the shoulders; lines of bristles and prescutellar area pruinose. Legs brown, L.R. I.5, pulvilli absent. Wings cuneiform and with long fringe, macrotrichia present at 
apex, on veins and as lines around margin of anal cell and along centres of cells $\mathrm{R}_{5}$ and $\mathrm{M}_{2}$ almost to their bases ; $\mathrm{R}_{4+5}$ ending just basal to level of apex of $\mathrm{M}_{3+4}$. Halteres brown. Abdomen dark brown; hypopygium (Text-fig. I5, b) differing from chambiensis in the presence of a row of dots on the anal point and in the shorter, truncate appendage $2 a$; styles stout, appendage I broad and curved.

Female very similar to male, wings not more heavily covered with macrotrichia.

Holotype male and I $\widehat{\delta}$, I $q$ paratypes CAPE Province : Berg River, Driefontein, xii.I954 (K. M. F. Scott). Further paratypes-Natal: I ô, 2 우, Tugela River, Drakensburg, 5,000 ft., ix.I953 (A. D. Harrison). All specimens are in the British Museum.

\section{Genus ZAVRELIA Kieffer}

Zavrelia Kieffer, I9I4, in Bause, Arch. Hydrobiol. Suppl. $2: 73$; Goetghbuer, 1938, in Lindner, Flieg. Pal. Reg. 3 (г 3 c) : 95.

Tanytarsus subg. Zavrelia Edwards, 1929, Trans. ent. Soc. Lond. $77: 419$.

Eyes pubescent, male antenna with II segments, female antenna with 5 or 6 segments, small frontal tubercles present, scutellum with several marginal bristles, combs of tibiae small and separate, both with long slender spurs in the single African species, pulvilli absent, wings cuneiform, $\mathrm{R}_{4+5}$ ending distinctly before level of tip of $\mathrm{M}_{3+4}$.

The single African species falling into this genus differs from the Palaearctic species by the presence of a slender spur on each tibial comb, by the peculiar appearance of the male hypopygium and by the much broader wings. However, the pubescent eyes and short radius cause it to fall very easily into Zavrelia where I am leaving it for the present. Discovery of the larva will show whether it resembles the Palaearctic species in the case-bearing larval habit.

\section{Zavrelia kribiensis Kieffer}

Zavrelia kribiensis Kieffer, 1923, Ann. Soc. ent. France, $92: 167$.

A minute brown insect with greenish abdomen, wings thickly clothed all over with macrotrichia; easily separated from other species of the Tribe by the pubescent eyes and by the reduced and narrow male styles. Although I have not seen the type which is probably lost, the thickly clothed wings and presence of two tibial spurs suggest that the Cape specimens are of the same species as Kieffer's.

Male. Wing length $0.9 \mathrm{~mm}$.

Head yellowish brown, antennae with II segments, A.R. about $0 \cdot 5$, eyes strongly pubescent, small frontal tubercles present. Thorax yellowish with brown stripes and postnotum; dorso-central and acrostichal bristles long, scutellum with four long bristles. Legs pale yellowish brown, L.R. I 8 , pulvilli absent, tibial combs small and well separated, each with a long thin spur. Wings cuneiform, thickly clothed all over with macrotrichia; $\mathrm{R}_{4+5}$ ending well before level of apex of $\mathrm{M}_{3+4}$, halteres with dark tips. Abdomen either pale green or else with slightly darker bands at the incisures; hypopygium (Text-fig. I5, c) highly characteristic and quite unlike the 
Palaearctic species nigritulus Goetghebuer; anal point stout, coxite rounded, appendage I greatly exaggerated, I $a$ absent, 2 sinuous, $2 a$ bent and expanded at apex, especially in side view ; styles finger-like and with three long hairs at apex.

Female similar to male in colour and wing structure, antennae with 6 segments, the last 2 subequal.

The holotype female is probably lost, type locality French Cameroons : Kribi.

Distribution. CAPe Province: I ô, Berg River, Driefontein, xii.r954 and I ô, I ㅇ, French Hoek Forest Reserve, iii.I955 (K. M. F. Scott).

\section{UNRECOGNIZED SPECIES AND GENERA OF TANYTARSINI DESCRIBED BY KIEFFER}

Tanytarsus africanus, I9I3, Voy. All. Jean. Afr. Or. Ins. Dipt. 1:26. Based on a pale male and female from Kenya : Taveta. Only a female remains in spirit in the Muséum National d'Histoire Naturelle, Paris ; it was separated by Kieffer from other species by the moniliform antennal segments and fusion of segments 5 and 6.

T. misorus, I9I3, ibid. : 26. Based on a pale female with dark knees from KenYA : Ramisi ; type not marked in the Paris Museum, but it is not impossible for it to be an earlier description of Stempellina chambiensis.

T. tropicalis, I9I3, ibid.: 27. Described from a yellow female from KenYa: Taveta; again separated from others by details of antennae, in absence of males cannot be associated with known species.

T. brachyopsis, I9I3, ibid.: 27. The female type, which is in the Paris Museum, is pale with dark thoracic markings, type locality KENYA : Kijabe. Kieffer separated it from the others by the last antennal segment being twice as long as the preceding and by the wings being covered all over with macrotrichia.

T. apicalis, I9I3, ibid. : 28, was described from females, now in Paris Museum (Kenya: Taveta), which are yellow with brown thoracic markings, similar to brachyopsis, but separated from that species by the wing macrotrichia being confined to the apex.

Kribiobius Kieffer, I92I, Ann. Soc. ent. France, $90: 3$ I. This genus was erected to include a female now lost, with bare wings, two tibial spurs and 6-segmented antennae, the last segment being swollen basally and carrying a verticil. From the leg proportions it seems possible that this was a species of Tanytarsus even though he mentions that the cross-vein was oblique and the membrane bare. However, species of Tanytarsus in spirit often have wings appearing bare and Kieffer was quite unreliable in his use of the term "oblique" for the cross-vein, I am, therefore, tentatively placing Kribiobius as an unknown genus of the Tanytarsini.

$K$. modestus, I923, ibid. 92: I65; yellowish with thoracic markings sandy, length 2 mm., type female lost, locality French Cameroons : Kribi.

Clinotanytarsus, I92I, ibid. 90: 34. This genus has no real points of difference from Tanytarsus except that the cross-vein is described as oblique. Following Edwards (r929), I am assuming it to be a probable synonym.

C. nilicola, I923, ibid. 92: 169 is the type species of the genus; it is large, $3-3 \cdot 2$ 
$\mathrm{mm}$. long, the abdomen has brown incisures but the thoracic markings are pale; no figure is given of the male hypopygium and I have not found it possible to identify the species from the material at my disposal. Type series lost, locality Sudan : S. of Khartoum.

Hexatanytarsus, I92I, ibid. 90: 34 is separated from Clinotanytarsus by the 6segmented female antennae, very short empodium and single tibial spur. It is probably a synonym of Tanytarsus.

$H$. albiradix, I923, ibid. 92: I70 was described from a whitish female with blackbrown thoracic markings ; the wings were sparsely hairy in the distal part, posterior fork strongly distal to cross-vein; type lost, locality French CAMERoons: Kribi.

Paratanytarsus Bause was used by Kieffer, I923, ibid. 92 : I7I for seven species of which all the types are lost. Six were known in the female only and no figure was given of the male hypopygium of that of which the male was known (hirtipes). P. hirtipes and niloticus were from SUDAN: Shambe; longiceps, kribiensis, brevitibia, brevicornis and sessilis were from FRENCH CAMEROONS : Kribi. As with other species, he separated them on details of antennal and leg structure and also on mesonotal colour: I have not been able satisfactorily to recognize any of them.

Tanytarsus nilobius, I923, ibid. 92 : I76 was described from a yellowish female from SuDAN: Mongola; antennae with 5 segments, wings covered with macrotrichia, posterior fork well distal to cross-vein. It is not possible to recognize this species. 


\section{INDEX TO GENERA AND SPECIES IN STUDIES OF AFRICAN CHIRONOMIDAE, PARTS I-IV}

The Roman numeral refers to the Part and the Arabic to the page within that Part; synonyms are in italics.

Ablabesmyia, I, 20 and 35 abyssiniae, Polypedilum, IV, 279 aculeatus, Chironomus, III, 393 aculeatus, Chironomus, III, 386 acuminatus, Chironomus, III, 344 acutistilus, Chironomus, III, $35^{2}$ acutus, Chironomus, III, 397 aegyptium, Polypedilum, IV, 28I aegyptius, Chironomus, III, 394 aequatoris, Chironomus, III, 367 africana, Thalassomyia, I, 66 africanus, Cardiocladius, II, 32 I africanus, Chironomus, III, 339 africanus, Clunio, I, 65 africanus, Coelotanypus, I, 5 I africanus, Tanytarsus, IV, 356 aïrense, Polypedilum, IV, $28 \mathrm{I}$ Akiefferiella, II, 338 albiclava, Trichocladius, II, 316 albicoxa, Stenochironomus, III, 4I4 albida, Polypedilum, IV, 299 albiforceps, Chironomus, III, 402 albipes, Stictochironomus, IV, 307 and 308 albiradix, Tanytarsus, IV, 357 albitalus, Procladius, I, 58 albitarse, Chironomus, III, 378 albitibia, Cricotopus, II, 306 alboguttatum, Polypedilum, IV, 287 albomarginatus, Chironomus, III, 34I albosignatum, Polypedilum, IV, 286 albus, Microtendipes, IV, 3I4 allansoni, Polypedilum, IV, 283 Allocladius, II, 346

alluaudi, Chironomus, III, 337 alpinus, Orthocladius, II, 336 alticola, Polypedilum, IV, 272 alticola, Polypedilum, IV, 304 anale, Polypedilum, IV, 303 analis, Thienemanniella, II, 365 Anatopynia, I, 44 angustistilus, Nanocladius, II, 34I angustus, Cricotopus, II, 3I 2 angustus, Tanytarsus, IV, 335 annulaticrus, Microtendipes, IV, 3I6 annulatipes, Polypedilum, IV, 277 annulator, Pentaneura, I, 22 and II, 288 annulatum, Polypedilum, IV, 295 antennalis, Stenochironomus, III, 4 I 2 antennata, Thienemanniella, II, 367 anuke, Stictochironomus, IV, 307 apicalis, Chironomus, III, 34I apicalis, Procladius, I, 58 apicalis, Tanytarsus, IV, 356 appendiculata, Ablabesmyia, I, 40 apricus, Chironomus, III, 339 armatifrons, Polypedilum, IV, 288 ater, Chironomus, IV, 400 aterrimus, Tanytarsus, IV, 338 atomarius, Tanytarsus, IV, 337 atra, Smittia, III, 348

atriclava, Cricotopus, II, 305 atrocinctus, Tanytarsus, IV, 335 atroconus, Stenochironomus, III, 4I5 atrofasciatus, Chironomus, III, 404 aurantiacus, Pentaneura, I, 33 avicula, Chironomus, III, 353

Baeotendipes, III, 349

baeus, Chironomus, III, 406 balteatus, Tanytarsus, IV, 333 Belgica, I, 64

bellus, Chironomus, III, 335 benoiti, Metriocnemus, II, 302 bergensis, Cricotopus, II, 3 I 2 bergensis, Orthocladius, II, 33I bicinctum, Microtendipes, IV, 3I6 bicinctus, Pentaneura, I, 40 biclavatus, Chironomus, III, 348 biclavatus, Chironomus, III, 399 bifalcatum, Polypedilum, IV, 29I bifasciatus, Microtendipes, IV, 316 bifurcus, Tanytarsus, IV, 337 biloba, Nanocladius, II, 343 binotatus, Chironomus, III, 367 bipunctatus, Stenochironomus, III, 4I 2 bipustulatum, Polypedilum, IV, 298 bipustulatus, Stenochironomus, III, 4I 2 bisignatus, Stictochironomus, IV, 309 bizonatus, Cricotopus, II, 306 Boreochlus, I, I9 brachyopsis, Tanytarsus, IV, 356 bredoi, Chironomus, III, 369 brevibucca, Chironomus, III, 375 brevicornis, Chironomus, III, $35 \mathrm{I}$ brevicornis, Chironomus, III, 405 brevicornis, Paratanytarsus, IV, 357 brevimanus, Chironomus, III, $35 \mathrm{I}$ brevipalpis, Chironomus, III, 376 brevipalpis, Tanypus, I, 49 brevipecten, Polypedilum, IV, 285 brevipetiolatus, Procladius, I, 56 brevis, Limnophyes, II, 344 brevistilum, Polypedilum, IV, 273 brevitarsis, Nanocladius, II, 342 brevitibia, Paratanytarsus, IV, 357 brincki, Chaetocladius, II, 330 
brincki, Chironomus, III, 399

brunneicornis, Polypedilum, IV, 295

brunnescens, Chironomus, III, 39I

brunneum, Polypedilum, IV, 296

brunneus, Chironomus, III, 339

brunneus, Nanocladius, II, 340

Bryophaenocladius, II, 325

burgeoni, Chironomus, III, 375

caffrarium, Chironomus, III, 375

caffrarius, Chironomus, III, 339

caffrarius, Stictochironomus, IV, 307

calcaratus, Polypedilum, IV, 292

caligans, Chironomus, III, 378

calipterus, Chironomus, III, 343

callichirus, Chironomus, III, 34I

Calochironomus, III, 356

Calopsectra, IV, 343

caloptera, Microtendipes, IV, 3I6

calvescens, Polypedilum, IV, 300

camelus, Chironomus, III, 392

Camptocladius, II, 346

Camptokiefferiella, II, 338

canus, Metriocnemus, II, 297

capensis, Chironomus, III, 339

capensis, Metriocnemus, II, 301

capensis, Smittia, II, 359

capensis, Tanytarsus, IV, 349

capensis, Trichocladius, II, 3 I 7

capicola, Micropsectra, IV, $33^{\circ}$

capicola, Smittia, II, $35^{8}$

Cardiocladius, II, $32 \mathrm{I}$

Carteria, III, 356

Carteronica, III, 356

cereofasciatus, Trichocladius, II, 3I 8

Chaetocladius, II, 325

chambiensis, Chironomus, III, 368

chambiensis, Stempellina, IV, 353

Charadromyia, I, 66

Chironomus, III, 329

chloronotus, Chironomus, III, $37 \mathrm{I}$

cinereithorax, Chironomus, III, 39I

Cladopelma, III, 382

Cladotanytarsus, IV, 348

claripennis, Clinotanypus, I, 52

claviger, Nanocladius, II, 34I

clavigera, Kribiodosis, IV, 324

Clinotanypus, I, 52

Clinotanytarsus, IV, 356

Clunio, I, 64 and 65

Coelotanypus, I, 50

collarti, Chironomus, III, 367

collarti, Pentaneura, I, 40

Collartiella, III, 4I 8

comata, Pentaneura, I, 34

conicus, Metriocnemus, II, 298

conicus, Orthocladius, II, 332

congoensis, Pentaneura, I, 36

congolensis, Chironomus, III, 342

conigera, Smittia, II, 35I

contracticornis, Pentaneura, I, 43

cordatus, Chironomus, III, 365

coronatus, Chironomus, III, 398

Corynoneura, II, 36I

Cricotopus, II, 303

crispi, Chironomus, III, 374

cristata, Corynoneura, II, 363 crosskeyi, Paratendipes, III, 420

Cryptochironomus, III, 382

cygnus, Pentaneura, I, 24

Dactylocladius, II, 3I 3

dampfi. Stictochironomus, IV, 307

decem-maculatum, Polypedilum, IV, 284

declivis, Polypedilum, IV, 289

deletum, Polypedilum, IV, 274

Demeijerea, III, 35I

deribae, Chironomus, III, 395

dewulf, Chironomus, III, 376

dewulfii, Corynoneura, II, 362

dewulfi, Metriocnemus, II, 300

dewulfi, Polypedilum, IV, 297

dewulfi, Tanypus, I, 49

dewulfi, Trichocladius, II, 3 I 4

dewulfianus, Chironomus, III, 397

Diamesa, I, 62

dibalteatus, Cricotopus, II, 3I 2

diceras, Chironomus, III, 390

Dicrotendipes, III, 356

digitata, Pentaneura, I, 36

disparilis, Chironomus, III, 353

distans, Kribiodosis, IV, 324

duboisi, Chironomus, III, 335

duodecimpustulatum, Polypedilum, IV, 279

dusoleili, Pentaneura, I, 4I

ealae, Chironomus, III, 369

eastopi, Chaetocladius, II, 330

edwardsi, Pentaneura, I, 28

edwardsi, Stenochironomus, III, 4I6

Einfeldia, III, 330

elongata, Corynoneura, II, 364

elongatum, Chironomus, III, 378

Endochironomus, III, 35I

ephippium, Nanocladius, II, 342

ephippium, Polypedilum, IV, 292

Eretmoptera, I, 64

Eucorynoneura, II, 36I

Eudactylocladius, II, 325

Eukiefferiella, II, 338

Euphaenocladius, II, 346

excerptus, Chaetocladius, II, 328

fasciata, Kribiodosis, IV, 324

fasciatipennis, Microtendipes, IV, 3I6

fasciatus, Chironomus, III, 346

fenestratum, Polypedilum, IV, 276

festivus, Stictochironomus, IV, 305

filitarsis, Polypedilum, IV, 276

fimbriatum, Chironomus, III, 390

flava, Thienemanniella, II, 368

flavipes, Microtendipes, IV, 317

flaviventris, Chironomus, III, 40I

flaviventris, Kribiodosis, IV, 324

flavozonatus, Cricotopus, II, 307

fletcheri, Metriocnemus, II, 297

fletcheri, Smittia, II, 348

flexistilus, Tanytarsus, IV, 342

forcipatus, Chironomus, III, 394

fordi, Metriocnemus, II, 30I

forficula, Chironomus, III, 362

formosipennis, Chironomus, III, 345

fractilobus, Chironomus, III, 378

fulgens, Cricotopus, II, 304 
fusca, Nilodosis, III, 407

fuscipenne, Polypedilum, IV, I 88

fuscipennis, Telmatogeton, I, 66

fuscipes, Chironomus, III, 39I

fuscitarsis, Chironomus, III, 386

fuscithorax, Kribiodosis, IV, 324

fuscoguttata, Lauterborniella, IV, 320

fusconotatus, Chironomus, III, 362

fuscum, Polypedilum, IV, 274

fuscus, Tanypus, I, 50 and II, 290

fuscus, Tanytarsus, IV, 347

fusiformis, Stictochironomus, IV, 309

Gillotia, III, 382

glabripennis, Polypedilum, IV, 296

gracilis, Knepperia, II, 360

graminicolor, Chironomus, III, 402

grisea, Nilodosis, III, 407

griseoguttatum, Polypedilum, IV, 284

griseonotatus, Chironomus, III, 362

griseosparsus, Chironomus, III, 362

griseovittatum, Chironomus, III, 364

guineensis, Chironomus, III, 336

guineensis, Smittia, II, 353

guineensis, Tanytarsus, IV, 346

guineensis, Trichocladius, II, 3I6

guttatipennis, Tanypus, I, 49

Halirytus, I, 65

Halliella, III, 349

hamata, Smittia, II, $35^{8}$

hamatus, Chironomus, III, 355

hamoni, Polypedilum, IV, 302

Harnischia, III, 382

harrisoni, Cricotopus, II, 305

harrisoni, Smittia, II, 355

harrisoni, Stenochironomus, III, 4I 4

Harrisonina, II, 318

henrardi, Chironomus, III, 37I

Henrardia, III, 408

Heptagyia, I, 62

hessei, Cardiocladius, II, 324

heterostolus, Smittia, 357

hexastictus, Chironomus, III, 343

Hexatanytarsus, IV, 357

hieroglyphicum, Polypedilum, IV, 284

hirsti, Chironomus, III, 400

hirsuta, Collartiella, III, 4I 8

hirsuta, Pentaneura, I, 3I

hirtella, Smittia, II, 355

hirtipes, Paratanytarsus, IV, 357

Hulstaertiella, IV, 3 Io

Hydrobaenus, II, 330

imicola, Chironomus, III, 346

imperforatus, Stictochironomus, IV, 306

incoloripenne, Polypedilum, IV, 276

inflexus, Chironomus, III, 403

interrupta, Pentaneura, I, 33 and II, 289

ivicolor, Chironomus, III, 345

iris, Polypedilum, IV, 28I and 286

Isoplastus, I, 20

ituriensis, Nilodosis, III, 407

kibatiense, Polypedilum, IV, 294

kijabensis, Polypedilum, IV, 304

kikuyui, Chironomus, III, 405 kinangopi, Orthocladius, II, 337

kisantuensis, Cricotopus, II, 304

Knepperia, II, 35I

kribiense, Polypedilum, IV, 298

kribiensis, Cricotopus, II, 306

kribiensis, Paratanytarsus, IV, 357

kribiensis, Pentaneura, I, 36

kribiensis, Stenochironomus, III, 4I 2

kribiensis, Smittia, II, 359

kribiensis, Zavrelia, IV, 355

kribiicola, Chironomus, III, 368

Kribiobius, IV, 356

Kribiocallis, IV, 304

Kribiocharis, IV, 268 and 310

Kribiocladius, II, 364

Kribiocosmus, IV, 318

Kribiocryptus, III, 382

Kribiodorum, IV, 319

Kribiodosis, IV, 324

Kribiodoxa, III, 4I9

Kribiomimus, IV, 268 and 310

Kribiomyia, IV, 328

Kribionympha, IV, 268

Kribiopelma, IV, 298

Kribiophilus, IV, 268

Kribiothauma, IV, 327

Kribiotima, IV, 268

Kribioxenus, III, 424

Kribioxenus, IV, 328

lacteus, Clinotanypus, I, 54

lacteiforceps, Chironomus, III, 404

lacustris, Tanypus, I, 48

lacustris, Orthocladius, II, 337

lamprogaster, Microtendipes, IV, 3 12

Lasiodiamesa, I, I9

laterale, Polypedilum, IV, 292

latilobus, Chironomus, III, $37 \mathrm{I}$

latistilus, Cardiocladius, II, 322

Lauterborniella, IV, 3 I9

lentiginosus, Microtendipes, IV, 3I 5

Lepidopodus, IV, 327

leptogastrus, Chironomus, III, 343

leucochlorus, Chironomus, III, 338

leucolabis, Chironomus, III, 367

leucolabis, Polypedilum, IV, 276

leucopus, Chironomus, III, 387

lewisi, Chironomus, III, 394

lewisi, Tanytarsus, IV, $35^{\circ}$

limnocharis, Polypedilum, IV, 296

Limnochironomus, III, 356

Limnophyes, II, 344

linea, Chironomus, III, 345

linearis, Chironomus, III, 343

linearis, Tanytarsus, IV, 352

lineola, Thienemanniella, II, 367

lindneri, Chironomus, III, 387

lobeliae, Metriocnemus, II, 296

lobiferum, Polypedilum, IV, 289

lobiger, Orthocladius, II, 332

Lobodiamesa, I, 62

longiceps, Paratanytarsus, IV, 357

longicornis, Chironomus, III, 339

longicosta, Smittia, 353

longicostalis, Smittia, II, 353

longicrus, Polypedilum, IV, 279

longiforceps, Polypedilum, IV, 288 
longinervis, Pentaneura, I, 29 longinervis, Polypedilum, IV, 290 longipalpis, Kribiomyia, IV, 329 longipes, Pentaneura, I, 32 longiventris, Chironomus, III, 386 longiventris, Lauterborniella, IV, 322 longiventris, Polypedilum, IV, 288 luctuosus, Tanytarsus, IV, 339 luteipes, Microtendipes, IV, 3 I 8

\section{Macropelopia, I, 44}

maculatus, Clinotanypus, I, 54 maculipennis, Smittia, II, 349 maculosipennis, Tanypus, I, 48 maculosus, Procladius, I, 60 and II, 290 magna, Chironomus, III, 378 mahensis, Metriocnemus, II, 303 mahensis, Smittia, II, 353 marginatus, Pentaneura, I, 43 marmorata, Anatopynia, I, 45 Maoridiamesa, I, 62 mcmillani, Tanytarsus, IV, 34I megalochirus, Orthocladius, II, 336 meilloni, Cricotopus, II, 3I I meilloni, Pentaneura, I, 3I melaleuca, Pentaneura, I, 38 melaleucus, Chaetocladius, II, 327 melanophilus, Polypedilum, IV, 296 melanostola, Smittia, II, 357 melutensis, Chironomus, III, 398 metallescens, Trichocladius, II, 3I 7 Metriocnemus, II, 294 micra, Pentaneura, I, 34 micra, Polypedilum, IV, 302 micans, Trichocladius, II, 3I4 Microcricotopus, II, $33^{8}$ micronyx, Stenochironomus, III, 4I 5 Micropsectra, IV, 330

Microtendipes, IV, 3Io minimus, Pentaneura, I, 33 minor, Telmatogeton, I, 67 misorus, Tanytarsus, IV, 356 modestus, Kribiobius, IV, 356 monilis, Chironomus, III, 404 monilis, Pentaneura, I, 4I multispinosus, Chironomus, III, 373

nairobii, Chironomus, III, 334 Nanocladius, II, 338 natalense, Polypedilum, IV, 273 natalensis, Chaetocladius, II, 328 natalensis, Limnophyes, II, 344 natalensis, Stictochironomus, IV, 306 neonilicola, Chironomus, III, 389 nigerrimus, Orthocladius, II, 335 nigra, Smittia, II, 349

nigra, Smittia, II, 352

nigratipes, Lepidopodus, IV, 326 nigricornis, Tanytarsus, IV, 345 nigripalpis, Clinotanypus, I, 52 nigritarse, Chironomus, III, 375 nigrocinctus, Tanytarsus, IV, 339 nigrocorporis, Chironomus, III, 387 nigrolineatus, Chironomus, III, 370 nigromarmorata, Pentaneura, I, 27 nigropunctatum, Chironomus, III, 379 nigrovittatus, Clinotanyus, I, 52 niliacus, Chironomus, III, 343

nilicola, Chironomus, III, 345,362 and 389

nilicola, Orthocladius, II, 337

nilicola, Procladius, I, 59

nilicola, Tanytarsus, IV, 356

niligenus, Chironomus, III, 386

niligenus, Clinotanypus, I, 52

nilobius, Tanytarsus, IV, 357

Nilodorum, III, 374

Nilodosis, III, 406

Nilomyia, III, 382

nilophilus, Chironomus, III, 405

nilophilus, Stictochironomus, IV, 307

Nilotanypus, I, 20

nilotes, Chironomus, III, 405

Nilothauma, III, 424

nilotica, Pentaneura, I, 36

niloticum, Polypedilum, IV, 279

niloticus, Chironomus, III, 37I

niloticus, Chironomus, III, 392

niloticus, Paratanytarsus, IV, 357

niloticus, Procladius, I, 59

nivalis, Chironomus, III, 34I niveiforceps, Polypedilum, IV, 278 niveipluma, Nanocladius, II, 339 nocticolor, Polypedilum, IV, 296 nocticolor, Tanytarsus, IV, 336 noctivaga, Chironomus, III, 35 I noctivagus, Procladius, I, 59 novemguttatum, Polypedilum, IV, 278 nubilipennis, Paratendipes, III, 422 nudiforceps, Chironomus, III, 404

obscurus, Cricotopus, II, 3I I obscurus, Tanypus, I, 50

obsoletum, Polypedilum, IV, 274 octomaculatum, Pentaneura, I, 28 octomaculatum, Polypedilum, IV, 277 octostictum, Polypedilum, IV, 277

oculare, Chironomus, III, 405

ocularis, Chironomus, III, 406

Odontomesa, I, 62

oliffi, Cardiocladius, II, 322

ornatipennis, Polypedilum, IV, 272

ornatipes, Kribiocosmus, IV, 319

Orthocladius, II, 330

Orthosmittia, II, 346

ovazzai, Chironomus, III, 350

ovazzai, Pentaneura, II, 289

oxylabis, Chironomus, III, 345

pallida, Polypedilum, IV, 299 pallidinervis, Polypedilum, IV, 290 pallidipes, Lauterborniella, IV, 323 pallidissima, Pentaneura, I, 30 pallidissimus, Tanytarsus, IV, 337 pallidissimus, Tanytarsus, IV, $33^{8}$ pallidulus, Kribioxenus, IV, 328 pallidulus, Tanytarsus, IV, 333 pallidus, Chaetocladius, II, 330 palpalis, Chironomus, III, 346 palpalis, Pentaneura, I, 32 palpalis, Pentaneura, II, 289 palustris, Chironomus, III, 345 pandani, Polypedilum, IV, 295 Paraclunio, I, 65

Paracorynoneura, II, 36I 
Parakiefferiella, II, 338

Paratanytarsus, IV, 357

Paratendipes, III, 4I9

Parochlus, I, I9

penicillatus, Chironomus, III, 374

Pentaneura, I, 20

Pentapedilum, IV, 298

Pentapelma, IV, 268

peringueyanus, Chironomus, III, 364

peringueyi, Chironomus, III, 337

petersi, Anatopynia, I, 47

petricola, Harrisonina, II, 319

Phaenocladius, II, 346

pictipenne, Nilothauma, III, 425

pictipennis, Chironomus, III, 36I

pictipennis, Polypedilum, IV, 279

pictipes, Pentaneura, I, 43

pictiventris, Chironomus, III, 345

pictiventris, Cricotopus, II, 3 IO

pictus, Chironomus, III, 365

pilosimanus, Chironomus, III, 360

plumbeus, Cricotopus, II, 306

pluriguttatum, Stictochironomus, IV, 307

Podonomus, I, I9

polychaetus, Stenochironomus, III, 4I 2

Polypedilum, IV, 266

polytomus, Procladius, I, 60

pretorianus, Orthocladius, II, 336

pretorianus, Trichocladius, II, 3 I6

Procladius, I, 56

Prodiamesa, I, 62

productus, Chaetocladius, II, 329

Protanypus, I, 62

Protenthes, I, 47

pruina, Polypedilum, IV, 280

Psammathiomyia, I, 65

Psectrocladius, II, 324

Psectrotanypus, I, 20 and 44

Pseudodiamesa, I, 62

pseudolabis, Chironomus, III, 387

pseudomancus, Tanytarsus, IV, $34^{8}$

Pseudorthocladius, II, 330

Pseudosmittia, II, 346

Psilotanypus, I, 56

pubescens, Chironomus, III, 402

pulchellum, Kribiothauma, IV, 327

pulcher, Chironomus, III, 334

pulchra, Lauterborniella, IV, 32 I

pullatus, Chironomus, III, 4 OI

pumilio, Chironomus, III, 406

puripennis, Stictochironomus, IV, 307

puripennis, Stictochironomus, IV, 309

pustulatus, Stenochironomus, III, 4I 7

pygmaeus, Chironomus, III, 406

pygmaeus, Stenochironomus, III, 4ro

quadrifasciatus, Cricotopus, II, 3 Io

quadrispinosa, Henrardia, III, 409

quatuordecimpunctatus, Chironomus, III, 36I

quatuorpunctatum, Chironomus, III, 362

quinqueguttatum, Polypedilum, IV, 279

ramiferum, Polypedilum, IV, 285

rectilobus, Smittia, II, $35 \mathrm{I}$

reductus, Chironomus, III, 402

reductus, Orthocladius, II, 332 reductus, Pentaneura, I, 43

reductus, Tanytarsus, IV, $35^{\circ}$

regalis, Chironomus, III, 373

reginae, Chironomus, III, 346

reidi, Chironomus, III, 399

reidi, Paratendipes, III, 42 I

reidi, Procladius, I, 6I

remotissima, Pentaneura, I, 35

Rheotanytarsus, IV, 346

rhodesiae, Chironomus, III, 406

rhodesianus, Chironomus, III, 400

rodriguensis, Cricotopus, II, 306

Rosenia, IV, 298

rostratiforceps, Chironomus, III, 343

rostrifer, Chironomus, III, 347

ruandae, Polypedilum, IV, 299

rudebecki, Chironomus, III, 400

rufa, Pentaneura, I, 40

rugosum, Chironomus, III, 378

rugosus, Clinotanypus, I, 55

rutshuruensis, Microtendipes, IV, 3I4

rutshuruensis, Pentaneura, I, 27

ruwenzoriensis, Chaetocladius, II, 328

ruwenzoriensis, Diamesa, I, 62

salti, Smittia, II, 349

sancti-benedicti, Orthocladius, II, 337

sancti-pauli, Telmatogeton, I, 66

satchelli, Chironomus, III, 338

satchelli, Microtendipes, IV, 312

schoutedeni, Chironomus, III, 370

schultzei, Chironomus, III, 348

schwetzi, Anatopynia, I, 45

schwetzi, Chironomus, III, 334

scottae, Cricotopus, II, 3 I 2

scotti, Chironomus, III, 335

scotti, Corynoneura, II, 362

scotti, Metriocnemus, II, 298

scotti, Polypedilum, IV, 297

sensualis, Chironomus, III, 334

septemguttatum, Pentaneura, I, 28

septemguttatum, Polypedilum, IV, 279

sessilis, Paratanytarsus, IV, 357

sexguttatum, Polypedilum, IV, 279

seychelleanus, Chironomus, III, 34 I and 367

seychellensis, Corynoneura, II, 364

seydeli, Chironomus, III, 347

seydeli, Paratendipes, III, 424

similis, Orthocladius, II, 334

sinuatus, Chironomus, III, 393

Smittia, II, 346

spadiceonotatus, Tanytarsus, IV, 34I

spatuliger, Stenochironomus, III, 4IO

speciosus, Chironomus, III, 36I

spinosa, Limnophyes, II, 344

Stempellina, IV, 352

Stenochironomus, III, 409

Stictochironomus, IV, 304

stictoptera, Paratendipes, III, 423

stictoptera, Stictochironomus, IV, 305

stilatum, Chironomus, III, 375

stilatum, Polypedilum, IV, 294

stilifer, Chironomus, III, 395

striata, Paratendipes, III, 423

subconfluens, Polypedilum, IV, 29I

subfusiformis, Chironomus, III, 405

subnigra, Smittia, II, $35^{2}$ 
subovatus, Chironomus, III, 390

subovatum, Polypedilum, IV, 282

subrecta, Pentaneura, I, 36

subreflexens, Tanytarsus, IV, 344

subtrilobata, Smittia, II, 357

sudanicus, Chironomus, III, 365

sudanicus, Cricotopus, II, 308

surdellus, Chironomus, III, 376

Syndiamesa, I, 62

tangae, Chironomus, III, 335

taitae, Microtendipes, IV, 316

Tanypus, I, 20

Tanypus, I, 47

Tanytarsus, IV, 33I

tavetae, Chironomus, III, 343

teesdalei, Pentaneura, I, 26

Telmatogeton, I, 65 and 66

tenuimanus, Polypedilum, IV, 290

tenuitarsis, Polypedilum, IV, 276

Tethymyia, I, 64

tetraleucus, Chironomus, III, 348

Thalassomyia, I, 65

Thienemanniella, II, 364

tinctoria, Pentaneura, I, 26

transvaalensis, Chironomus, III, 339

Trichocladius, II, 303

Trichocladius, II, 3I 3

Trichotanypus, I, I9

Trichotanypus, I, 47 and 56

tricinctellus, Cricotopus, II, 308

tricolor, Pentaneura, I, 36

tridens, Polypedilum, IV, 282

trifascia, Pentaneura, I, 25

trifidus, Chironomus, III, 39I

trifidus, Tanytarsus, IV, 343

trilabis, Chironomus, III, 362

trilobatum, Polypedilum, IV, 280

Tripedilum, IV, 268

Tripodura, IV, 268

tripunctatus, Chironomus, III, 334 trisetosus, Chironomus, III, 38I

trispinosa, Stenochironomus, III, 4Io

Trissoclunio, I, 66

trivittata, Thienemanniella, II, 365

tropicalis, Chironomus, III, 405

tropicalis, Tanytarsus, IV, 356

tropicum, Polypedilum, IV, 280

truncata, Stempellina, IV, 353

ugandae, Chironomus, III, 380

umbrosus, Microtendipes, IV, $3 \mathbf{I} 3$

umbrosus, Procladius, I, 56

unicalcar, Chironomus, III, 4 OI

unicolor, Anatopynia, I, 46

uniformis, Pentaneura, I, 30

van-bemmeli, Polypedilum, IV, 284

vanderplanki, Polypedilum, IV, 297

vaneyeni, Chironomus, III, 335

variiforceps, Pentaneura, I, 43

verbekei, Clinotanypus, II, 290

verbekei, Cricotopus, II, 31 3

violaceus, Lauterborniella, IV, 32 I

viridescens, Psectrocladius, II, 325

viridiventris, Chironomus, III, 386

vitellinus, Nanocladius, II, 339

vitshumbiensis, Chironomus, III, 376

vittatum, Polypedilum, IV, 300

wittei, Metriocnemus, II, 295

wittei, Polypedilum, IV, 30I

woodi, Chironomus, III, 355

wulfi, Smittia, II, 354

xanthostolus, Smittia, II, 357

Xenochironomus, III, 380

zariae, Tanytarsus, IV, 342

Zavrelia, IV, 355

Zavreliella, IV, 319

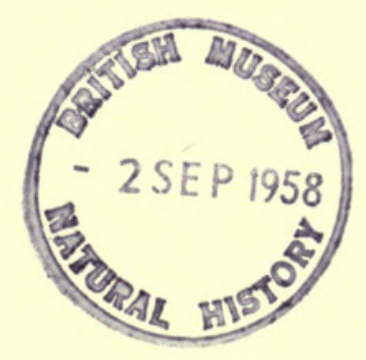




\section{$2 \mathrm{BHL}$ Biodiversity Heritage Library}

Freeman, Paul. 1958. "A study of the Chironomidae (Diptera) of Africa south of the Sahara, part IV." Bulletin of the British Museum (Natural History) Entomology 6, 261-363. https://doi.org/10.5962/bhl.part.17110.

View This Item Online: https://www.biodiversitylibrary.org/item/19419

DOI: https://doi.org/10.5962/bhl.part.17110

Permalink: https://www.biodiversitylibrary.org/partpdf/17110

\section{Holding Institution}

Natural History Museum Library, London

\section{Sponsored by}

Natural History Museum Library, London

\section{Copyright \& Reuse}

Copyright Status: In copyright. Digitized with the permission of the rights holder.

Rights Holder: The Trustees of the Natural History Museum, London

License: http://creativecommons.org/licenses/by-nc-sa/4.0/

Rights: http://biodiversitylibrary.org/permissions

This document was created from content at the Biodiversity Heritage Library, the world's largest open access digital library for biodiversity literature and archives. Visit BHL at https://www.biodiversitylibrary.org. 